\title{
Investigating the Mechanism Behind the Release of Microcystins in Freshwater Cyanobacteria
}

by

\author{
Rossella Nicolai
}

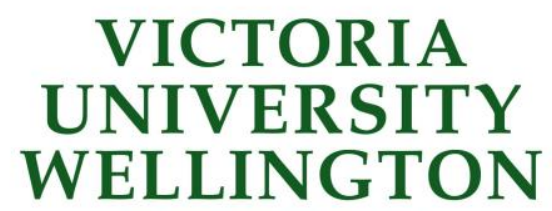

TE WHARE WĀNANGA

O TE ÜPOKO O TE IKA A MĀUI

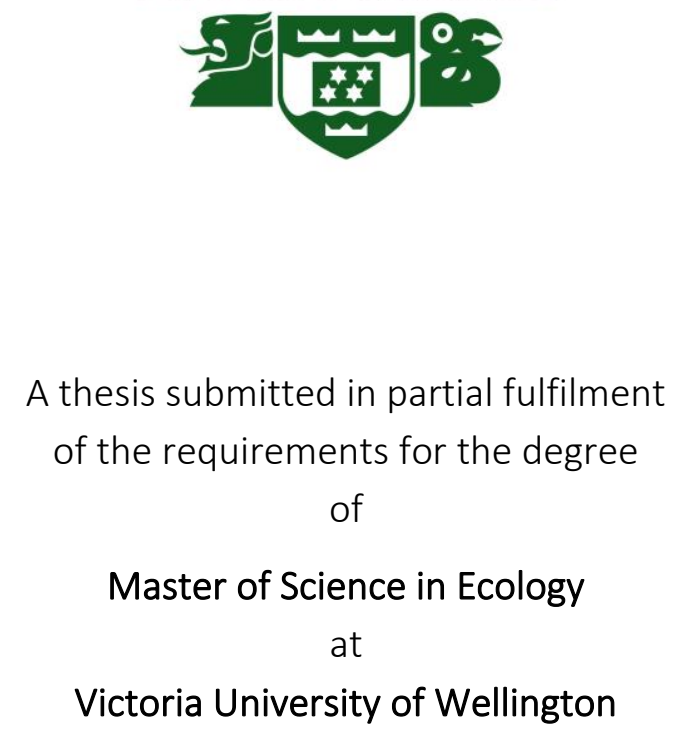




\section{ABSTRACT}

The frequency and distribution of toxic cyanobacterial blooms are increasing globally, creating the need for a better understanding of the processes involved in toxic secondary metabolite production. Microcystins (MCs) are potent hepatotoxins produced by a wide range of bloomforming cyanobacteria genera such as Microcystis and Planktothrix. Although the release of MCs to the extracellular environment has long been considered a by-product of cell lysis and death, several studies suggest the presence of a mechanism that actively transports these toxins outside the cell membrane. The aim of the present study was to find evidence for a link between cell lysis and concentrations of extracellular MCs.

A dual-fluorescence cell viability assay using the nucleic acid stain SYTOX Green was optimised for use on Microcystis and Planktothrix. A SYTOX Green concentration of $1 \mu \mathrm{M}$, and an incubation time of 30 minutes, yielded a bright and even fluorescent signal that readily identified lysed cells.

The improved staining technique, in conjunction with liquid chromatography-mass spectrometry analyses, was employed in a culturing experiment to track the transfer of MCs to the extracellular environment in relation to the amount of cell lysis. For Microcystis, there was a strong and significant positive relationship between cell lysis and the concentration of extracellular MC. When the extracellular MC was predicted according to cell lysis levels and the MC content per cell, lysed cells were a major contributor of MCs to the extracellular environment, although the model overestimated the concentrations. Relationships for 
Planktothrix were significant but weaker, possibly due to reduced accuracy in the cell enumeration step, which would have altered the calculated MC content per cell.

Whilst these findings support the hypothesis that cell lysis is the main contributor of extracellular MCs, the results do not exclude a role of MCs as signalling molecules. The recent finding that programmed cell death may occur in Microcystis under various environmental conditions may explain the commonly observed increase in extracellular MCs. Understanding the mechanisms involved in the transfer of MCs to the extracellular environment will provide further clarification on the function of these secondary metabolites and lead to the improvement of water quality management strategies. 


\section{ACKNOWLEDGEMENTS}

To Prof. Ken Ryan and Dr Jonathan Puddick, I would like to express my deepest appreciation for the time and care you have devoted to helping me realize this project over the last two years. Thank you for supporting me throughout this journey, spurring me on with your love and enthusiasm for science. And especially thanks for making yourselves so available during the turmoil of the past few months, making me feel like I could always count on you during such difficult times. Your dedication, patience, and enthusiasm for science have truly been inspiring, and I will always cherish the memories of this time.

To my mum and dad, thank you from the bottom of my heart for giving me the life-changing opportunity to come to New Zealand and study at VUW, despite this pulling me to the other side of the world. The love, trust, and respect you demonstrate to me every day have been my power source through the most difficult times. Thanks to my brothers Luca and Giordano for always encouraging me, and for the fun stories and visions of pizza you share.

A big thank you to all my friends and colleagues at the Cawthron Institute, Nelson, for making my time there so memorable. To Susie Wood and Lesley Rhodes, thank you for the interest expressed in my research, it was an immense pleasure to get to know you and work with you. I would like to extend my gratitude to Eric Goodwin, for developing the R scripts for the image analyses of Chapter 2, to Georgia, for the help with my statistical analyses, and to Veronica, for 
doing such an amazing job keeping the ETW lab running, for your formidable sense of humour, and for helping out whenever something went wrong,

Thank you to Marie, for being my anchor in this crazy period, and for always warming my heart with your kindness, curiosity, and love for others. Thanks to Bobby and Justyna, for believing in me and for making my postgraduate time at VUW so much fun. I never laugh as much as when the three of us are together! Thanks to Ronja, Jenna, Brittany, Tory, Li, and the eco-pals for venturing into this journey with me. I will never forget the late nights at university, the Hunter Lounge beers after handing in an assignment, and the cool group projects we did together, it all made my studies extra special. I would also like to thank Roberta and Davide for keeping me sane over lockdown - when boredom filled the room and motivation was hard to find.

Thanks to Glenn for reading over Chapters 1 and 3, and to the Gebbie family for being so close to me during my time at university, especially Harry. You are the person who better witnessed all the madness behind every exam and every essay I wrote, and I am extremely grateful you were by my side to emotionally support me and encourage me.

Finally, I would like to thank Victoria University of Wellington for these beautiful years, and the Marsden fund of the Royal Society of New Zealand for the financial support received under the Blooming Buddies project (CAW1601).

"Apporcooooo!"

- Dad 


\section{Table of Contents}

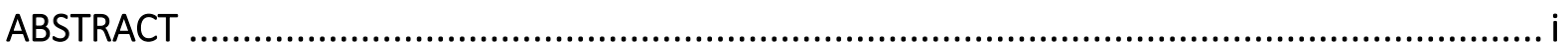

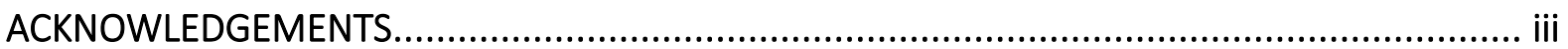

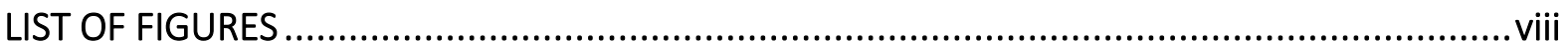

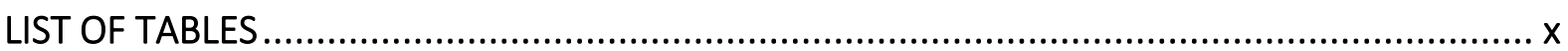

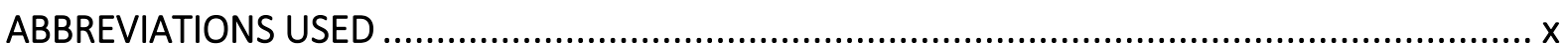

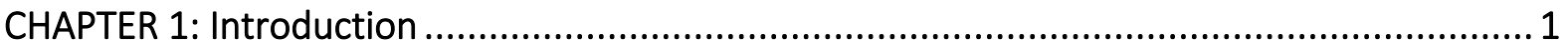

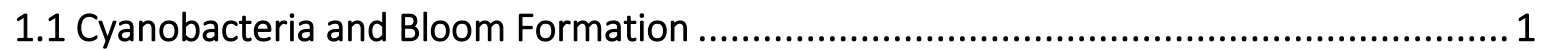

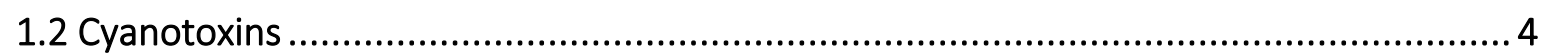

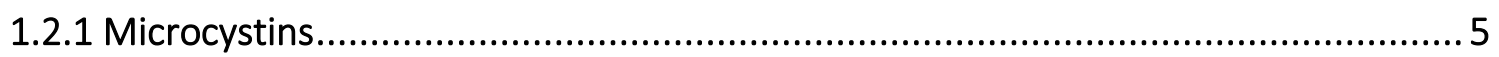

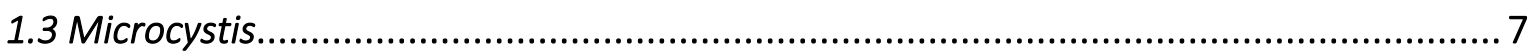

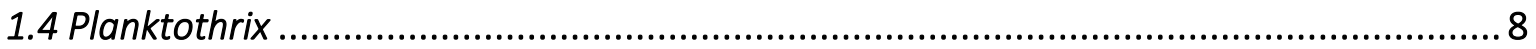

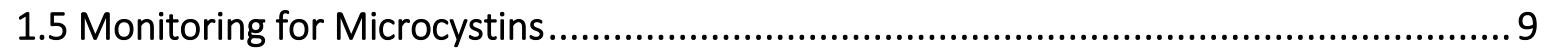

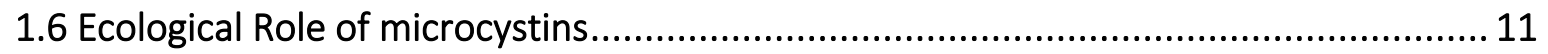

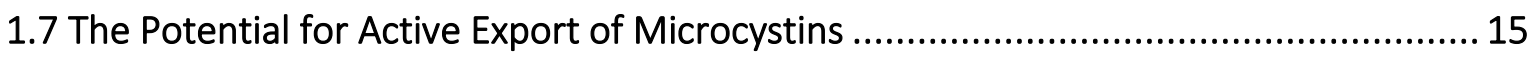

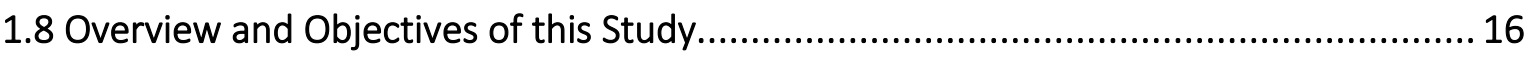

CHAPTER 2: OPTIMISATION OF SYTOX GREEN STAINING METHOD WITH MICROCYSTIS AND

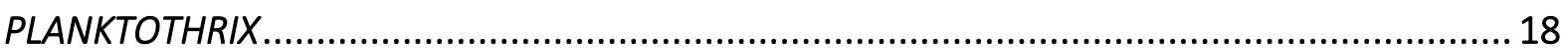

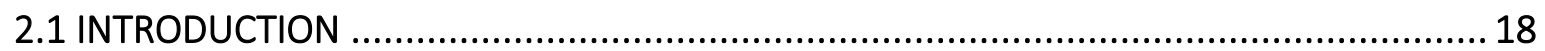


2.2.1 Cyanobacteria Cultures and Materials

2.2.2 Permeabilisation of Cyanobacteria

2.2.3 Optimisation of SYTOX Green Dye Concentration

2.2.4 Optimisation of SYTOX Green Incubation time

2.2.5 Testing the Accuracy of the SYTOX Green Dual-Fluorescence Cell Viability Assay . 24

2.2.6 Fluorescence Microscopy Analysis 24

2.2.7 Half-life Evaluation of Permeabilised Cyanobacteria 25

2.2.8 Image Analysis 26

2.2.9 Statistical Analysis 27

2.3 RESULTS 28

2.3.1 SYTOX Green concentration 28

2.3.2 SYTOX Green Incubation Time 31

2.3.3 Accuracy of the SYTOX Green intact/lysed assay. 34

2.3.4 Half-life Evaluation of Permeabilised Cyanobacteria 36

2.4 DISCUSSION 38

2.5 CONCLUSIONS 40

CHAPTER 3: INVESTIGATING THE POTENTIAL ACTIVE EXPORT OF MICROCYSTINS IN CYANOBACTERIA 


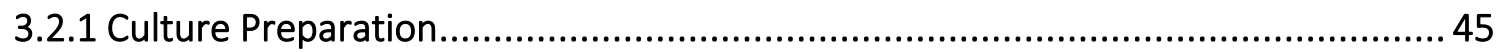

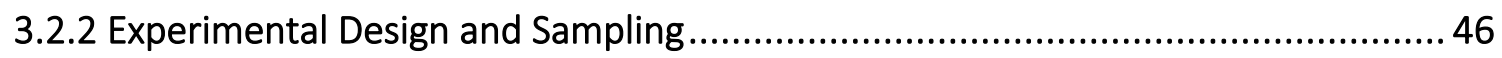

3.2.3 Dual Fluorescence Intact/Lysed Assay ........................................................ 46

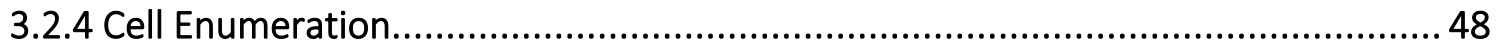

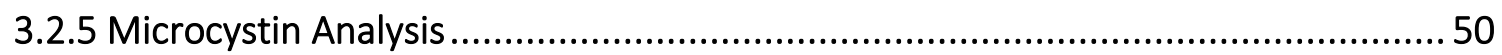

3.2.6 Prediction of Extracellular MC Concentration Using Lysed Cell Concentration...... 54

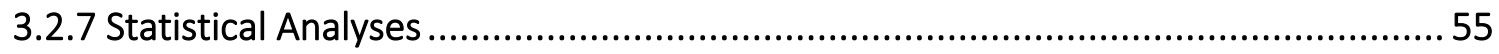

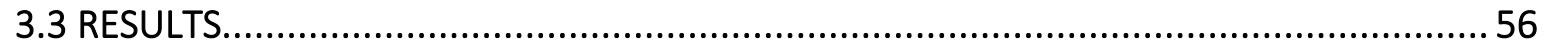

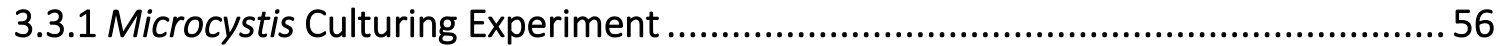

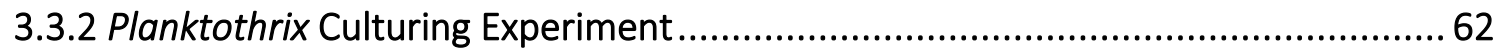

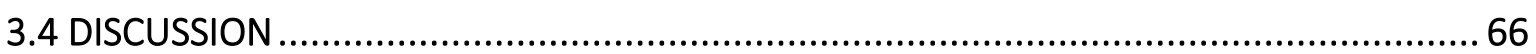

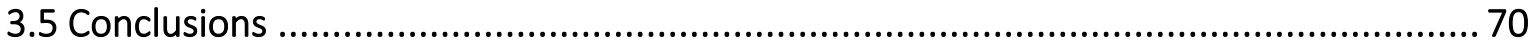

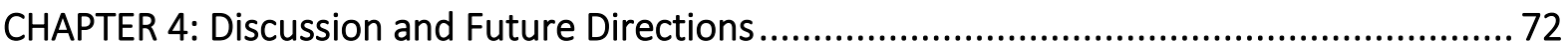

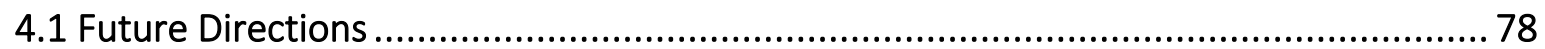

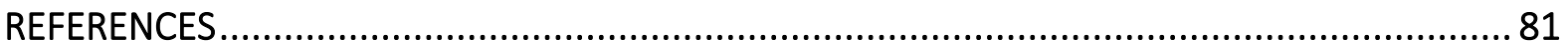




\section{LIST OF FIGURES}

Figure 1.1 Satellite images of cyanobacterial blooms (from Huisman et al. 2018) 2

Figure 2.1 Images of lysed Microcystis cells detected under an epifluorescence microscope with a FITC filter at final concentrations of $0.05,0.5$ and $5 \mu \mathrm{M}$ SYTOX Green stain. 28

Figure 2.2 Fluorescence intensity of chemically lysed samples of Microcystis at final SYTOX Green stain concentrations of $0.05,0.1,0.2,0.5,1,2$, and $5 \mu \mathrm{M}$ (note the log-scale on the $y$ axis). 29

Figure 2.3 Images of lysed Planktothrix cells detected under an epifluorescence microscope with a FITC filter at concentrations of $0.05,0.5$ and $5 \mu \mathrm{M}$ SYTOX Green stain. 30

Figure 2.4 Fluorescence intensity of chemically lysed samples of Planktothrix at final SYTOX Green stain concentrations of $0.05,0.1,0.2,0.5,1,2$, and $5 \mu \mathrm{M}$ (note the log-scale on the $y$ axis). 31

Figure 2.5 Mean fluorescence intensity of Microcystis (A) and Planktothrix (B) lysed cells after incubation in SYTOX Green stain for 5, 10, 20, 30, 40, and 50 minutes. 33

Figure 2.6 Regression analysis of fluorescently detected \% lysed cells vs known \% lysis for Microcystis (A) and Planktothrix (B). 35

Figure 2.7 Age of Dead cells against percentage of original Microcystis cell objects detected (A) and age of dead cells against percentage of original fluorescence intensity detected in Planktothrix (B)..... 37 
Figure 3.1 Confocal microscopy images of Microcystis (left) and Planktothrix (right) samples stained using SYTOX Green stain. Red fluorescence indicates cells with intact cell membranes; green fluorescence shows SYTOX Green permeated cells; Scale bar $=10 \mu \mathrm{m}$ 56

Figure 3.2 Time series of cell concentration and microcystin (MC) quota in the Microcystis culture over the 57 day sampling period. Data correspond to mean \pm one standard error, $n=3$.

Figure 3.3 Time series of the concentration of extracellular microcystins (MCs) and the proportion of lysed and intact cells in the Microcystis cultures (A) and concentration of extracellular MC as a function of the concentration of lysed Microcystis cells (B). 59

Figure 3.4 Predictive model for the contribution to extracellular microcystins (MCs) from lysed Microcystis cells: without adjustment for excess lysed cells (A); with adjustment for excess lysed cells (B).

Figure 3.5 Time series of cell concentration and microcystin (MC) quota in the Planktothrix cultures over the sampling period. The datapoints correspond to the mean \pm one standard error, $n=3$.

Figure 3.6 Time series of the concentration of extracellular microcystins (MC) and the proportion of lysed and intact cells in Planktothrix cultures (A), and concentration of extracellular MC as a function of the concentration of lysed Planktothrix cells (B).......64

Figure 3.7 Predicted contribution of lysed cell microcystin (MC) to the extracellular environment, without adjustment for excess lysed cells (A), and with adjustment (B) for the Planktothrix cultures. 65 


\section{LIST OF TABLES}

Table 3.1 Liquid chromatography gradient for microcystin quantitation by LC-MS.........51

Table 3.2. Multiple reaction monitoring conditions for liquid chromatography. 52

\section{ABBREVIATIONS USED}

ACN, acetonitrile;

Adda, 3 S-amino-9 S-methoxy-2 S,6,8 S-trimethyl-10-phenyl-4,6-dienoic acid;

ATP, adenosine-5'-triphosphate;

$A B C$, adenosine triphosphate binding cassette;

ANOVA, analysis of variance;

DMSO; dimethyl sulfoxide;

DNA, deoxyribonucleic acid;

ELISA, enzyme-linked immunosorbent assay;

FA, formic acid;

FDA, fluorescein diacetate;

FISH, fluorescent in situ hybridization;

FOV, field of view; GF/C, glass fibre filter;

HPLC, high performance liquid chromatography;

LC, liquid chromatography;

$m c y$, microcystin synthetase gene cluster;

MC, microcystin(s);

min, minute(s)

MS, mass spectrometry;

MS/MS, tandem mass spectrometry;

$\mathrm{m} / \mathrm{z}$, mass-to-charge ratio;

$\mathrm{n}$, sample size;

$\mathrm{N}$, nitrogen; 
NRPS, non-ribosomal peptide synthetase;

$\mathrm{C}_{18}$, octadecyl carbon chain;

P, phosphorus;

PAR, photosynthetically active radiation;

$\mathrm{PI}$, propidium iodide;

PCD, programmed cell death;

PKS, polyketide synthase;

QPCR, quantitative polymerase chain reaction;

$\times g$, relative centrifugal force;

$\mathrm{s}$, second(s);

$\mathrm{v} / \mathrm{v}$, volume per volume ratio. 


\section{CHAPTER 1: Introduction}

\subsection{Cyanobacteria and Bloom Formation}

Cyanobacteria are photosynthetic prokaryotes that originated 3.5 billion years ago (Huisman et al., 2018); a long evolutionary history resulted in many adaptations and ecologically successful life strategies that allow members of this phylum to thrive in a wide range of environments, such as polar regions, oceans, lakes, rivers, desert soils, and geothermal hot springs (Omidi et al, 2018; Xiao et al., 2018). There are currently >270 cyanobacteria genera described, with $>3,000$ species found in planktonic and benthic habitats in marine, freshwater, as well as terrestrial systems (Komareck 2016; Huang et al., 2019). Cyanobacteria are commonly referred to as 'blue-green algae' because of their characteristic hue, caused by to the presence of the pigments phycocyanin (blue colored) and chlorophyll-a (green colored), which are often accompanied by the presence of other accessory pigments, such as carotenoids and phycoerythrin (Huisman et al., 2018).

Cyanobacterial dominance in aquatic systems can be explained by adaptations that allow them to efficiently exploit the resources available to them in the water column (Paerl and Paul, 2012). For example, some species are able to fix atmospheric nitrogen ( $N$ ), and many genera possess high affinity uptake and intracellular storage capabilities for phosphorus (P). This supports cellular metabolism and growth, by allowing them to access these nutrients under limiting conditions (Pearl et al., 2011; Braun et al., 2018). Other cyanobacterial species can adjust their buoyancy via gas vesicles, an adaptation to stratified waters which they can exploit 
to access photosynthetically active radiation (PAR) and $\mathrm{CO}_{2}$ on the surface (Zurawell et al. 2005; Renaud et al., 2011). By accumulating polysaccharides and increasing cellular turgor pressure, cyanobacteria can then reduce their buoyancy or cause their gas vesicles to collapse (Zurawell et al. 2005).

Under optimal conditions, cyanobacteria can rapidly proliferate and form extensive blooms that can be seen even from space (Fig. 1.1). Blooms are defined as a rapid increase in algal density, with the most ancient occurrence reported by the Romans in 77 AD (Huang et al. 2019).
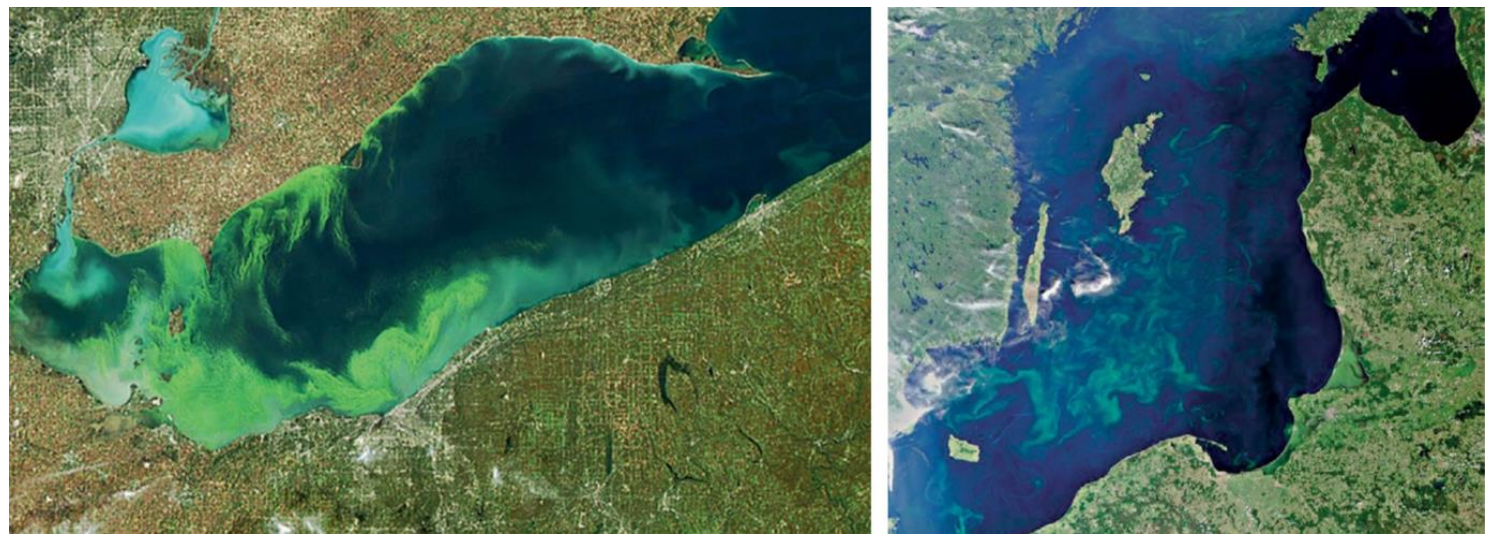

Figure 1.1 Satellite images of cyanobacterial blooms (from Huisman et al. 2018)

Anthropogenic activities may promote conditions that facilitate this cyanobacterial proliferation (Harke et al., 2016, Paerl et al., 2012). The dramatic increase in the availability of $\mathrm{N}$ and $\mathrm{P}$ resulting from agricultural activities (i.e., eutrophication), rising water temperatures, and the consequent stratification of the water column are the main factors driving bloom formation (Wood et al., 2011; O'Neil et al., 2012). In freshwater ecosystems, P is often the key limiting factor for cyanobacterial growth (Chaffin et al. 2018). Management procedures have therefore focused on reducing its input from agricultural activities (Lewis et al., 2008; Paerl et al., 2011). However, the resulting increase in the $N: P$ ratio in the water column favors the 
formation of blooms by genera that are not able to fix $\mathrm{N}$ (i.e., non-diazotrophic species) such as Microcystis and Planktothrix, which may also produce toxins (Huisman et al. 2018).

Bloom formation often occurs during late summer months, as most cyanobacteria species thrive at relatively high water temperatures $\left(>25^{\circ} \mathrm{C}\right.$; Paerl and Huisman, 2008). At this time of the year, more intense stratification of the water column occurs because the warm top layer does not mix with the cold bottom layer (Rabalais et al., 2017). Thermal stratification during warm months may be the main cause of bloom formation in Australia and Brazil, although high cyanobacterial biomass can also develop during periods of mixing (Dantas et al., 2011). Stratification of water bodies is particularly favorable for those species able to produce gas vesicles, which allow the cyanobacterium to adjust its buoyancy according to its needs (Smayda et al., 1997; O'Neil et al., 2012). As the bloom develops, the formation of scums on the water surface may lead to an increase in the temperature of the surrounding water, leading to a positive feedback process that maintains cyanobacterial dominance (Paerl et al., 2011; Stroom et al., 2016).

Cell aggregation and the formation of colonies has two major consequences: 1) decreased nutrient availability and light harvesting per cell, resulting in lower growth rates, and 2) enhanced buoyancy modulation (Yang et al., 2009). Microcystis aeruginosa, a species that forms large colonies in the natural environment, tends to disassociate into single cells if grown under laboratory conditions (Bolch and Blackburn, 1996). However, the same species aggregated when grown with a high concentration of zooplankton (Yang et al., 2009). The authors speculated that colony formation may be induced by the release of info-chemicals from the grazers, suggesting that this process is a defense mechanism adopted to reduce the risk of predation through an increased volume, as many grazers are extremely size selective. 
Among the bloom-forming genera of cyanobacteria, Dolichospermum (formerly Anabaena), Microcystis, Nodularia, Planktothrix, Cylindrospermopsis, and Trichodesmium are the most commonly reported (Kaebernick et al., 2002). Cyanobacteria blooms often have deleterious effects on aquatic ecosystems (Janssen et al., 2019). For example, when a bloom senesces, bacterial respiration can deplete the water of its oxygen content, leading to mass deaths of the fish and aquatic invertebrates inhabiting the hypolimnion (Kardinaal et al., 2007; Rabalais et al., 2017). Blooms are especially associated with negative effects in terms of the aesthetic and recreational value of freshwater, through the production of foul odors and reduced water potability (Zurawell et al. 2005). The damage to drinking, agricultural, and recreational water resources has been estimated to cost the USA > \$2.2 billion annually (Dodds et al. 2008). The main concern associated with bloom formation is that cyanobacteria can produce a variety of secondary metabolites that are toxic to plants and animals at naturally occurring concentrations (cyanotoxins; Fewer et al., 2007). Animal poisoning caused by the ingestion of cyanotoxins was first reported 142 years ago, when a Nodularia spumigena bloom formed in Lake Alexandrina (South Australia) and killed numerous sheep (Francis, G., 1878). In the past three decades, the frequency and distribution of harmful cyanobacterial blooms have increased dramatically (Neilan et al. 2013).

\subsection{Cyanotoxins}

Cyanotoxins are a diverse group of organic compounds, both in terms of their chemical structure and the nature of their toxicity to humans (Omidi et al. 2018). They are produced by a wide range of cyanobacteria, but Microcystis, Planktothrix and Dolichospermum (formerly Anabaena) are the most frequently reported toxin-producing genera in freshwater environments (Gagala et al., 2012). There are three main cyanotoxin chemical structures: cyclic 
peptides (microcystins and nodularins), heterocyclic alkaloid compounds (anatoxins, anatoxina(S), cylindrospermopsins, saxitoxins, aplysiatoxins) and lipopolysaccharides (Kaebernick \& Neilan, 2001; Stewart et al., 2006). Cyanotoxins are also classified into five groups, based on their effects on target organisms: (1) neurotoxins (anatoxins, anatoxin-a(S) and saxitoxins) affect the nervous system, disrupting the regular functioning of neuromuscular activities; (2) hepatotoxins (microcystins, nodularins, and cylindrospermopsins) are actively taken up by hepatocytes (i.e., liver cells) and can potentially lead to liver failure; (3) cytotoxins (cylindrospermopsins and alkaloids) inhibit protein synthesis, causing damage to the liver, kidneys, spleen, thymus, and heart; (4) dermatoxins (aplysiatoxins, debromoaplysiatoxins, lyngbyatoxins) affect the skin, causing dermatitis; (5) irritant toxins (endotoxins) are liposaccharides associated with the outer membrane of cyanobacteria, which elicit allergic reactions and can cause gastroenteritis and inflammation (Huisman et al., 2018).

\subsubsection{Microcystins}

Microcystins (MCs) are the most well-studied cyanotoxins, due to their widespread occurrence and high toxicity (Tillet et al., 2000). They form a large and structurally diverse group of cyclic heptapeptides produced non-ribosomally via a large enzyme complex comprised of peptide synthetases, polyketide synthases and additional tailoring enzymes. Non-ribosomal peptide synthetases (NRPSs) have a modular structure, with each module responsible for the activation, thiolation, modification, and condensation of one specific amino acid substrate (Christiansen et al. 2003). There are currently > 246 known variants of MCs reported (Huisman et al., 2018), which vary in peptide sequence, modifications, and toxicity (Rineheart et al., 1994; Sangolkar et al., 2006). One of the most toxic congeners, MC-LR, has recently been classified as potentially carcinogenic by the World Health Organization (WHO; Rogers et al., 2015). 
Amino acid substitutions in the MC variants often includes non-proteinogenic amino acids (Christiansen et al. 2003). The existence of such a wide array of variants may be explained by the amino acid composition of the water column when blooms form (Moore et al., 1991). While Microcystis may produce different MC isoforms with considerable variation at the second and fourth positions and with MC-LR, MC-YR, and MC-RR as the predominant toxins, Planktothrix is often dominated by the desmethyl variant of MC-RR (dmMC-RR; Christiansen et al. 2003).

Due to differences in the number of $\mathrm{N}$ atoms in variable amino acids incorporated into $\mathrm{MC}$, the availability of this nutrient in the water column may play an important role in controlling $\mathrm{MC}$ congener abundance (Puddick et al., 2016). Microcystins contain about $14 \% \mathrm{~N}$ by mass, yet the $\mathrm{N}$ content of Microcystis cells is approximately $7 \% \mathrm{~N}$ by dry mass (Chaffin et al. 2018). This stoichiometry suggests that $\mathrm{N}$ plays a vital role in cyanotoxin production. However, culturing experiments often show mixed results, sometimes finding no difference between the growth rates of potentially toxic and nontoxic isolates, grown in monocultures under optimal or suboptimal conditions (Chaffin et al. 2018). This suggests that factors other than nutrient form and availability may play a role in MC production.

The multi-enzyme complex responsible for $\mathrm{MC}$ biosynthesis is encoded by a relatively large gene cluster called MC synthetase (Nishizawa et al., 2000; Christiansen et al., 2003; Schatz et al., 2007). Phylogenetic studies of cyanobacteria capable of producing MCs have revealed a sporadic distribution of the MC synthetase cluster, caused by a partial or total loss of genes (Rantala et al., 2004; Christiansen et al., 2003). Microcystins are produced by several entirely different cyanobacteria, including unicellular, multicellular filamentous, heterocystous and non-heterocystous genera. Many strains can produce multiple MCs simultaneously, but usually 
only one or two of these are dominant in any single strain (Christiansen et al. 2003). The presence of the toxin in distantly related groups seems to be consistent with the early origin of MC production in cyanobacteria (Rantala et al., 2004).

Microcystins are transported by anion transport proteins to hepatocytes (i.e. liver cells), where they inhibit the activity of the protein phosphatases 1 and $2 \mathrm{~A}$, resulting in excessive signaling and potentially leading to cellular disruption and tumor promotion (Neilan et al., 2013, Puddick et al., 2019). Several deaths caused by MC intoxication have been reported in birds, fish, and mammals, as well as humans (Wood et al. 2011; Elliot, 2012). In 1996 for example, 76 patients at a Brazilian hemodialysis center died of acute liver failure after being exposed to MCs in the water used for dialysis (Jochimsen et al., 1998). Concentrations as low as $50-70 \mathrm{mg} \mathrm{kg}^{-1}$ have been reported to cause mortality in humans (Neilan et al., 2013).

\subsection{Microcystis}

The Microcystis genus comprises unicellular cyanobacteria commonly encountered in eutrophic fresh waters, which frequently produce MCs and form colonies (Yoshida et al., 2008). The ability to form colonies and gas vesicles is crucial to the success of Microcystis in lake systems. These features enable fast vertical migration, offering them an advantage over other photosynthetic organisms (Kehr et al., 2006). While M. aeruginosa, M. flos-aquae, M. ichtyoblable, M. novacekii, and M. wesenbergii comprise both MC-producing and non-MCproducing strains, strains of $M$. viridis have only been shown to produce MCs to-date (Yoshida et al., 2008, Zilliges et al., 2008). Microcystins in this genus are produced continuously from the early logarithmic phase to the late stationary phase of a bloom (Lyck, S., 2004). Although MC production is generally constitutive, abiotic factors or growth can affect MC cellular content in Microcystis by a factor of 3-4 (Jacinavicius et al. 2019). Under P-limitation, non-toxic 
Microcystis strains have a light quantum efficiency that is higher than that of their toxic counterparts. This suggests that blooms where toxic and non-toxic strains coexist will tend to be dominated by toxic Microcystis cells first, while non-toxic cells take over during the senescence stage, when nutrients are scarce (Wang et al. 2015).

\subsection{Planktothrix}

Planktothrix is one of the most prolific MC producing genera in temperate lakes (Catherine et al., 2008). Within the order Oscillatoriales, the genus Planktothrix is generally characterised by free-floating solitary trichomes distinguished in nine planktonic species, although a benthic strain was isolated in a freshwater biofilm in New Zealand (Wood et al., 2010) and more recently by Pancrace et al. (2017). The significance of Planktothrix blooms for public health became evident after an incident where soldiers suffered facial rashes, asthmatic symptoms and dry sporadic cough with vomiting after exposure to Planktothrix agardhii during canoe training in Hollingworth Lake, England (Codd et al., 1999). Individual P. agardhii strains may produce up to six different non-ribosomal peptides simultaneously (Janse et al., 2005). Both MC-producing and non-producing genotypes have been found for $P$. agardhii and $P$. rubescens (Janse et al., 2005).

The types of MC isoforms produced by Planktothrix often differ from that in Microcystis, and cellular production rates of the toxin have been found to generally be higher in filamentous strains from field studies (Christiansen et al., 2003). While most mcy genes present in Planktothrix have counterparts in the mcy clusters of Microcystis, the modules mcyF and mcyl are lacking in Planktothrix and mcyT is missing in Microcystis. While in Microcystis the mcy genes are organised in two operons transcribed in opposite directions, in Planktothrix mcy genes, except mcyT, are transcribed from the same DNA strand from a single operon. 
Planktothrix agardhii is reported to produce more toxic MC variants during warm months, when recreational activities in lakes are most attractive (Tonk et al., 2005).

\subsection{Monitoring for Microcystins}

Monitoring of planktonic cyanobacteria in New Zealand waterbodies used for recreational activities generally follows the protocols and thresholds set out in the 'Interim New Zealand Guidelines for Cyanobacteria in Recreational Fresh Waters' (Ministry for the Environment and Ministry of Health, 2009). These biovolume thresholds were established using toxicity calculations based on the negative health effects of MCs, the likelihood of exposure to the toxins, and the expected MC cell quota (Puddick et al., 2019). It is difficult to predict the potential health risk posed by these toxins, because their concentration greatly varies within each bloom (Briand et al., 2012). Microcystin levels may increase dramatically in dense scums, such that estimates of $25,000 \mu \mathrm{g} \mathrm{L^{-1 }}$ have been reported in lakes where the guideline limit for safe recreational water is $20 \mu \mathrm{g} \mathrm{L}^{-1}$ (Kardinaal et al., 2007). The presence of MCs in water bodies is regularly monitored using techniques that allow toxins to be detected and quantified in both natural and controlled environments, such as drinking water treatment plants, or clinical and pathological materials (Metcalf et al., 2009). Microcystin concentrations in environmental samples can be estimated using protein phosphatase inhibition assays, enzyme-linked immunosorbent assays (ELISAs) generally targeting the Adda portion of the MC structure, chemical derivatisation with gas chromatography-mass spectrometry analysis, and highperformance liquid chromatography (HPLC) in conjunction with either UV absorption or mass

spectrometry (MS) detection (Metcalf et al., 2009; Rogers et al., 2015). Liquid chromatography-MS (LCMS) is a highly-specific analytical technique where complex mixtures 
of compounds are separated by LC (generally using a reversed-phase $\mathrm{C}_{18}$ column) and analysed according to their mass-to-charge ratio ( $\mathrm{m} / \mathrm{z}$ ) by MS (Guo et al., 2017).

All of these techniques are still in use, as they encompass a wide range of sensitivities, selectivities, and equipment costs, thus making it possible to choose analyses that meet specific requirements (Rogers et al., 2015; Guo et al., 2017). However, this wide range of measurement techniques also calls for the use of standardised procedures, to ensure that meaningful comparisons can be made between diverse datasets. Usually, the toxin biomass is concentrated by centrifugation or filtration through glass-fiber filters (GF/C), and then stored at a temperature $\leq-20{ }^{\circ} \mathrm{C}$, or is lyophilized $\left(<196{ }^{\circ} \mathrm{C}\right.$; Rogers et al., 2015). The extraction procedure usually involves the use of solvents (e.g., methanol or butanol), freeze/thaw cycles, sonication, or microwave-enhanced extraction (Rogers et al., 2015). One of the greatest difficulties encountered in co-culturing studies is that it is not possible to distinguish between toxic and non-toxic strains of the same species, on the basis of their morphology, thus excluding the use of traditional microscopy or flow cytometry for this purpose (Renaud et al., 2011). There is no apparent correlation between cell morphology and MC production (Yoshida et al., 2007), although it is sometimes possible to distinguish between cells, according to the type of photosynthetic pigments present (e.g., Kardinaal et al., 2007). However, in most cases molecular biology techniques are needed to determine the composition, and variation thereof, of strains within a bloom.

The genetic pathways for MC production have been characterised, and the genes involved in this process have been sequenced for many genera (Neilan et al., 2013). This proves particularly useful when adopting techniques such as quantitative PCR (or Q-PCR), which target specific genes within the MC synthase cluster (e.g. Kurmayer et al., 2003; Wood et al., 2011). 
An alternative technique is fluorescent in situ hybridization (FISH), which localizes MCencoding genes within a population, thus aiding a less-disruptive distinction between toxic and non-toxic strains within a bloom (Biegala et al., 2002; Zeller et al., 2016).

\subsection{Ecological Role of Microcystins}

The ecological role of MCs is still under debate and it is often difficult to compare results among a wide range of growth and toxicity assessment techniques (Kaebernick et al., 2000). However, it is conceivable that the function of the toxin may be related to factors that commonly enhance the production of peptides, such as culture age, temperature, light, nutrients, salinity, $\mathrm{pH}$, and micronutrient concentrations. All of these affect the $\mathrm{MC}$ content of $M$. aeruginosa, Anabaena flos-aquae and Planktothrix agardhii (Dittman et al., 2001). Culturing experiments demonstrated that MC-producing strains have an advantage over their non-toxic counterparts under stressful conditions, such as low carbon concentrations, elevated temperatures, oxidative stress, or bright light conditions (Omidi et al., 2018). The effects of $N$ and $P$ on the production and toxicity of MC are highly variable. While P-limited conditions increased toxicity in P. agardhii (Sivonen, K., 1990), and M. aeruginosa (Oh et al.2000), higher levels of both N and $\mathrm{P}$ are usually found to promote the proliferation of toxic Microcystis strains over non-toxic ones (Vezie et al. 2002). For instance, high levels of $N$ may promote the production of more toxic MC variants in M. aeruginosa (Oh et al. 2000).

Immuno-gold labeling techniques revealed that two-thirds of MCs were attached to the thylakoid membranes of producer cyanobacteria, leading to the hypothesis that $M C$ is involved in photosynthesis (Shi et al., 1995; Young et al., 2005). Although very low light intensities decrease MC production, so do light intensities above the optimal range (Van der Westhuizen \& Eloff, 1985), with no corresponding changes in growth rate (Kaebernick \& Neilan, 2001; 
Wiedner et al., 2003). The MC production rate generally depends on photon irradiance (Utkilen \& Gjølme, 1992; Wiedner et al., 2003). Light quality (at the red end of the visible light spectrum), as well as high light intensity, were responsible for an increase in mcyB and mcyD transcripts in $M$. aeruginosa cells, suggesting that the $M C$ synthetase gene cluster may require a certain irradiance threshold for initiation and up-regulation (Kaebernik et al., 2000). However, since numerous cellular processes are affected by light conditions, this is unlikely to be the only factor leading to these changes. For example, cell division is influenced by strong light, which may also have pronounced effects on transcription and/or toxin production (Wood et al., 2011). Under natural conditions, toxicity decreases with an increase in the depth of a bloom, suggesting there could be a negative relationship between toxin production and light penetration depth (Utkilen \& Gjølme, 1992). In contrast to most general findings concerning M. aeruginosa, Sivonen et al. (1990) reported that in a $P$. agardhii strain, a low level of irradiance (12 and $24 \mu \mathrm{mol}$ of photons $\mathrm{m}^{-2} \mathrm{~s}^{-1}$ ) resulted in higher $\mathrm{MC}$ concentrations than a higher level of irradiance ( 50 and $95 \mu \mathrm{mol} \mathrm{m} \mathrm{m}^{-2} \mathrm{~s}^{-1}$. However, the amino acid composition of MC produced by $P$. agardhii may vary substantially with light conditions, with more toxic variants being produced under higher irradiance (Tonk et al., 2005).

In addition to light, correlations between MC quota (toxin amount per cell) and a variety of other environmental factors such as water temperature, $\mathrm{pH}$, and nutrient availability (mainly $\mathrm{N}$ and $\mathrm{P}$ ) have been observed (Dai et al., 2016). Increasing temperature generally enhances toxicity, although temperatures exceeding $28^{\circ} \mathrm{C}$ lead to a reduction in $\mathrm{MC}$ concentrations (Van der Westhuizen \& Eloff, 1985). Colony size is also related to MC production, with larger colonies producing more than small ones (Jacinavicius et al., 2019). Iron deficiency triggered the production of toxins, suggesting that $\mathrm{MC}$ may contribute to the capture and incorporation 
of iron in the cytosol (Sevilla et al.,2008). Nonetheless, these findings were only correlative, and further experimental verification is required.

Microcystin production may have evolved as a defense mechanism against grazing (Rohrlack et al., 1999). However, phylogenetic analyses revealed that the major MC-producing genus Microcystis likely evolved well before the arrival of metazoan cyanobacteria predators (Rantala et al., 2004). This suggests that, although we cannot be sure that the genus originally produced MCs, these toxins plausibly had a different function when they first appeared.

Autotrophic organisms often release chemicals and toxins that negatively affect their potential competitors, a process known as allelopathy (Li and Li 2012). Tillmann (2003) and Graneli and Hansen (2006) found that allelopathy, especially toxin production, intensifies under limiting conditions, such as low nutrient levels. Moreover, many bacterial species produce signal molecules, such as acylated homoserine lactones and oligo-peptides, to synchronize cellular activities in response to environmental changes, through a process referred to as "quorum sensing" (Borges et al., 2019).

Schatz et al. (2007) suggested that these toxins may have a potential role in intercellular communication, and acclimation to changing environmental conditions. They found that the presence of toxins outside the cells further stimulated toxin biosynthesis via enhanced expression of the mcy gene cluster. Specifically, there was a 12-fold increase in the expression of the mcyB module in a fresh culture containing Microcystis cells, after these were exposed to a $24 \mathrm{~h}$ treatment with a crude extract obtained from mechanically lysed Microcystis cells. However, these effects cannot be directly linked to $M C$ because the crude extract contained other bioactive secondary metabolites known to be produced by some Microcystis strains, such as microviridins, microginin and aeruginosin, whose physiological role is also still poorly 
understood (Huang et al., 2019). While the same study by Schatz et al., (2007) revealed an increase in the expression of the mcyB module also in cultures treated with just MC-LR, this was of negligible magnitude.

For MCs to play a role as infochemicals in intercellular communication, they must first be released from the cells to the extracellular environment. During growth and under different environmental conditions, MCs are released partly to their surrounding media as extracellular molecules (Wood et al., 2012). The effects of exogenous MCs on non-toxic cyanobacteria are variable and their role is still under debate. As an example, Sedmak and Kosi (1998) reported an increase in the growth rate of a non-toxic strain of $M$. aeruginosa when exposed to MC-RR under low lighting conditions. However, exogenous MC-RR also caused growth inhibition, chlorosis, cell lysis, photosynthesis inhibition, and a change in pigment color of non-MCproducing cyanobacteria, when these were exposed to intense lighting conditions (Singh et al., 2001; Hu et al., 2004; Downing et al., 2015). The non-MC producing Synechococystis PCC6803 took up exogenous MC-LR at environmentally relevant levels, and stored it in thylakoid membranes (Phelan et al. 2014), which is where it is stored by the majority of MC-producing cyanobacteria (Wang et al. 2015). However, the addition of MC-LR led to a significant decrease in the activity of photosystem II.

Since quorum sensing is a cell-density dependent mechanism, the potential release of MCs may require a certain cell density threshold to be initiated. Strains of $M$. aeruginosa with different initial cell densities showed that the final cell density was positively correlated with the initial cell numbers (Dunn \& Manoylov, 2016), indicating that colonies proliferated in a cell density-dependent manner. In a mesocosm study, both Microcystis cell density and MC production increased by $14 \times$ over a period of $6 \mathrm{~h}$ (Wood et al., 2012), suggesting that MC 
production may also increase in a cell-density-dependent fashion. While concentrations of extracellular MC did not increase, this could be due to the time required to initiate toxin export. As MC quotas escalated in Lake Rotorua (Kaikoura, New Zealand), there was a corresponding increase in extracellular MC concentrations (Wood et al., 2011). The significant and rapid upand down-regulation of mcyE expression corresponding to variations in MC quota, extracellular MC levels and cell concentrations adds further evidence to support the hypothesis that these toxins may act as signaling compounds (Wood et al., 2011).

\subsection{The Potential for Active Export of Microcystins}

It is still not known whether MCs are exported to the extracellular environment by active transport, or whether the commonly observed increase in concentrations of extracellular MCs is a by-product of cell lysis. While little is known about the transport of organic substances through the membrane of cyanobacteria (Stebegg et al., 2019), the occurrence of protein transport through the cell membrane of cyanobacteria with surface layers in Synechocystis was reported (Agarwal et al., 2018), and some gram-negative bacteria can release outer membrane vesicles capable of long-distance transport (Bonnington et al. 2014). Some MCs have been detected in the cell wall and sheath area of $M$. aeruginosa cells, indicating the possible release of this toxin from intact cells (Shi et al., 1995). Moreover, although the release of MCs into the extracellular environment has long been attributed to the death and lysis of the blooms (Zurawell et al., 2005), there is evidence of a potential toxin export pathway. Genetic sequence analyses have shown a strong similarity between the $\mathrm{mcyH}$ module in the $\mathrm{MC}$ biosynthesis gene cluster and other ATP-binding cassette transporter genes, with homologs from plants, bacteria, nematodes and mammals involved in the transport of long-chain fatty acids structurally similar to the Adda sidechain of MCs (Pearson et al., 2004). However, inactivation 
of the putative transporter protein encoded by $m c y H$ in a mutant of $M$. aeruginosa led to complete blockage of $\mathrm{MC}$ production, preventing further functional characterisation of the $m c y H$ module. This suggests that the putative $M C$ export may be intrinsic to MC production.

A three-fold increase in the levels of MC-LR in M. pinniformis was detected during the light phase of a culturing experiment, for both light:dark and continuous light treatments, peaking at midday (Bittencourt-Oliveira et al. 2005). Levels of intracellular and extracellular MC also significantly oscillated under both continuous light and a light:dark cycle (12:12h), suggesting that the potential release of $\mathrm{MC}$ may be regulated by circadian rhythms and therefore that the toxins may play a key role in the central metabolism (Straub et al., 2011; Cordeiro-Araujo et al., 2013). Wiedner et al. (2003) found that extracellular levels of MC remained constant during the light:dark cycle, although the concentrations were 20 times higher at $40 \mu \mathrm{mol}$ of photons $\mathrm{m}^{-2} \mathrm{~s}^{-1}$ than at $10 \mu \mathrm{mol}$ of photons $\mathrm{m}^{-2} \mathrm{~s}^{-1}$. However, none of these studies was able to determine whether the cells were still alive when the toxins were being released to the extracellular medium, or whether the increase in extracellular MCs was due to increased cell lysis at higher irradiances. This is indicative of the need to couple cell viability techniques with a close monitoring of variations in the levels of extracellular MCs. The presence of an active transport mechanism to secrete the toxins would be partially supported by an increase in concentrations of extracellular MC regardless of cell lysis.

\subsection{Overview and Objectives of this Study}

The principal aim of this study is to address the hypothesis that cell lysis explains the concentration of extracellular MCs commonly observed in two major genera of MC-producing cyanobacteria: Microcystis and Planktothrix. To address this hypothesis, cell lysis was 
monitored during a culturing experiment using the nucleic acid stain SYTOX Green and was compared to the levels of extracellular MCs observed.

The SYTOX Green staining protocol was assessed and optimised for use on Microcystis and Planktothrix in Chapter 2, where the effects of different concentrations and incubation times on the fluorescence intensity of the dye were investigated and its accuracy was tested. This investigation was conducted to ensure the assay was reliable for detecting lysed cells during the culturing experiment described in Chapter 3.

In a culturing experiment conducted on Microcystis and Planktothrix (Chapter 3), the levels of cell lysis, as well as concentrations of extracellular MC, were monitored in an effort to understand whether the amount of toxins found in the medium could be explained by cell lysis. Evidence of the opposite case would provide further substantiation of a potential active export mechanism involved in the secretion of the toxins, therefore, supporting the role of MCs as signaling molecules.

In Chapter 4 the findings of these studies are discussed and future directions in this research area are provided. 


\title{
CHAPTER 2: OPTIMISATION OF SYTOX GREEN STAINING METHOD
}

\author{
WITH MICROCYSTIS AND PLANKTOTHRIX
}

\subsection{INTRODUCTION}

Toxic cyanobacteria blooms can negatively impact ecosystems, and the physiological state of the cells within a bloom can greatly alter its toxicity (Emerson et al., 2017). Monitoring for the presence and activity of cyanobacterial cells is therefore a pressing matter in environmental policy (Simis et al., 2012). Under stressful conditions or due to apoptosis, cells may sustain damage to their subcellular structures and physiological activities (Tashyreva et al. 2013). Cell lysis is a common and fundamental process in phytoplankton ecology, demanding the development of proper and fast methodologies to monitor cell viability (Peperzak et al., 2011).

Numerous colorimetric or staining assays have been developed to evaluate the cellular viability of micro-organisms. These techniques depend on one or both of two properties; the intactness of the cell membrane and the physiological state of the cell. Unlike dead cells, living, healthy and active cyanobacterial cells have intact plasma membranes and genomes, detectable metabolic activity, and significant content of pigments for effective photosynthetic performance (Zhu et al. 2013). A number of fluorescence-based assays that reflect various physiological functions are commercially available for detecting cell viability and activity, such as assessment of membrane integrity and potential, intracellular $\mathrm{pH}$, respiration intensity, intracellular enzymatic activity etc. (Tashyreva et al. 2013). The fluorescent probe fluorescein diacetate (FDA) has commonly been applied to assess cell viability of microalgae (Steinberg et 
al., 2011). The enzyme is cleaved by endogenous esterase activity following uptake into cells and results in the release of fluorescein, a compound that fluoresces bright green in metabolically active, viable cells. However, fluorescein rapidly leaks from cells, compromising the reliability of the results (Sato et al. 2004).

The loss of cell membrane integrity is one of the main features discriminating dead or severely injured cells from living cells, since it plays a key role in the operation of the whole cell and it is sensitive both to mechanical rupture and molecule driven alterations (Bischofberger et al. 2009). Assays intended for estimating membrane integrity are based on the passive exclusion of particular dyes (e.g., propidium iodide and SYTOX Green) by cells with structurally intact membranes (Tashyreva et al. 2015, Gallardo-Rodriguez et al. 2016). Ideal indicators of plasma membrane integrity concentrate only in cells with permeabilized membranes and exhibit marked fluorescence enhancement within these cells (Roth et al 1997). The efficacy of fluorescent compounds depends on their selectivity, brightness, excitation and emission maxima, and inherent biological toxicity (Roth et al. 1997). Because DNA and RNA provide large numbers of intracellular binding sites that promote marked fluorescence enhancement of many different stains, it is possible to obtain accurate information about the state of populations at a single-cell level (Roth et al., 1997). The application of fluorescent dyes makes the assessment of cell viability more accurate, rapid, and straightforward (Zhu et al. 2013). These dyes are often detected by fluorescent microscopy (Peperzak et al., 2011) but they can also be detected by solid state cytometry or flow cytometry (Berney et al. 2007). While the use of automated counting tools such as a flow cytometer significantly speeds up the process, fluorescence microscopy has the advantage of detecting low-biomass samples that might be more difficult to analyse with flow cytometry, where it may be difficult to distinguish them 
from the background (Emerson et al., 2017). For microscopy, the sample is stained and applied to a microscope slide, and the counts are performed manually or using image-processing software (Emerson et al., 2017).

Dual fluorescence assays are commonly used to assess cell viability, usually by employing differently coloured nucleic acid stains to differentiate between viable and non-viable cells (Berney et al. 2007). One example is the LIVE/DEAD BacLight viability assay kit widely employed for bacteria, which uses two nucleic acid binding probes, SYTO ${ }^{\circledR} 9$ and propidium iodide (Sato et al. 2004). SYTO 9 is a permanent intercalating green fluorescent dye capable of penetrating most plasma membranes and staining all cells containing nucleic acids, while propidium iodide is a red fluorescent dye that is normally membrane impermeable, and is thus excluded by the intact cell membranes of living cells. Non-viable cells will thus show fluoresce in the red end of the spectrum at $635 \mathrm{~nm}$, with excitation at $490 \mathrm{~nm}$ (Johnson et al. 2015). However, this overlaps with the excitation and emission wavelengths of pigments such as chlorophyll (Darzynkiewicz et al., 1994; Sato et al. 2004), making this assay generally not suitable for microalgae. Nonetheless, Zhu et al. (2013) report the successful application of SYTO 9 and propidium iodide on two cyanobacterial genera (Microcystis and Synechocystis).

SYTOX dyes are another important family of nucleic acid stains commonly used as a marker for cell lysis (Thakur et al. 2015). These dyes exhibit $>1,000$-fold fluorescence enhancement upon DNA binding, have a high DNA binding affinity, show little base selectivity, and exist in different colours spanning the whole visible spectrum, including SYTOX ${ }^{\circledR}$ Blue and SYTOX ${ }^{\circledR}$ Green. These have been applied to various species of cyanobacteria and algae (Sato et al., 2004). For instance, SYTOX Blue was used as an alternative to the non-viable cell indicator propidium iodide in the filamentous cyanobacterium Anabaena (Johnson et al., 2016). However, the dye 
also stained viable cells, possibly due to the passage of dye molecules through intercellular channels connecting cells within a filament (Mullineaux et al. 2008).

The SYTOX Green stain provides several advantages over the dyes described earlier due to its bright fluorescent signal, spectral properties, and relative non-toxicity to living cells (Tashyreva et al. 2013). Most importantly, SYTOX Green fluoresces bright green when excited with a 450$490 \mathrm{~nm}$ source (Sato et al. 2004), with optimal excitation wavelength at $504 \mathrm{~nm}$ and peak emission at $523 \mathrm{~nm}$ (Zetsche et al. 2011), which does not overlap with chlorophyll and phycobiliprotein fluorescence. This allows the simultaneous visualisation of intact and lysed cells in a simple dual fluorescence viability assay, where lysed cells fluoresce green (SYTOX Green) and intact cells fluoresce red (chlorophyll autofluorescence). Although there are reports of green autofluorescence by microalgae interfering with green-fluorescing stains, the SYTOX Green fluorescence is strong enough to outperform any green autofluorescence potentially emanating from microalgal cells (Tang et al. 2007). The dye has been successfully applied to bacteria, yeast cells, cyanobacteria, diatoms, dinoflagellates and green algae in both cultures and field samples for cell viability assessment (Veldhuis et al. 1997; Machado et al. 2012).

The manufacturer's recommended protocol for SYTOX Green is to use a concentration of 0.5 to $5 \mu \mathrm{M}$, incubating for $>5$ minutes in the dark at room temperature, however, there is much variability in the parameters used by researchers for different cyanobacterial genera (e.g., Sato et al., 2004; Bouma-Gregson et al., 2017; Tashyreva et al., 2015). The optimal concentration and incubation time of SYTOX Green may vary significantly from sample to sample depending on interspecific differences in permeability, state of the cultures, and on culture conditions prior to the staining procedure (Tashyreva et al., 2013). For instance, SYTOX Green was 
effective with two Synechocystis strains, Planktothrix agardhii and Microcoleus autumnalis, but not on Anabaena (Sato et al., 2004). Moreover, excessive dye concentrations and prolonged incubation periods resulted in heterogeneous staining of cell populations and overestimation of the proportion of lysed cells (Tashyreva et al. 2013), suggesting that different genera may require different staining procedures to ensure results reliability.

In the current study, I investigated the performance of the SYTOX Green stain for use with Microcystis aeruginosa and Planktothrix sp., to develop an optimised staining protocol. The optimal dye concentrations and incubation times were determined for each strain, the accuracy of the dual-fluorescence assay was assessed, and the half-life of the permeated cells was investigated for these two species. The optimised assay will later be applied to samples from the culturing experiment described in Chapter 3.

\subsection{METHODS}

\subsubsection{Cyanobacteria Cultures and Materials}

Microcystis aeruginosa CAWBG617 and Planktothrix sp. CAWBG59 were obtained from the Cawthron Institute Culture Collection of Microalgae (Cawthron Institute; Nelson, New Zealand) and grown in Erlenmeyer flasks in a climate chamber at $18{ }^{\circ} \mathrm{C}$ with a $12 \mathrm{~h}: 12 \mathrm{~h}$ light/dark photoperiod and a photon-flux of $90 \mu \mathrm{mol}$ photon $\mathrm{m}^{-2} \mathrm{~s}^{-1}$. SYTOX Green was supplied by the manufacturer in a $250 \mu \mathrm{L}$ tube at a concentration of $5 \mathrm{mM}$ in dimethyl sulfoxide (DMSO). The stain was diluted to $1 \mathrm{mM}$ using DMSO and, to preserve its integrity, was stored as individual stock solutions $(500 \mu \mathrm{L})$ in amber glass vials at $-20^{\circ} \mathrm{C}$. 


\subsubsection{Permeabilisation of Cyanobacteria}

Samples of Microcystis and Planktothrix $(10 \mathrm{~mL})$ were centrifuged at 4,000 $\times \mathrm{g}$ for $20 \mathrm{~min}$ in $15 \mathrm{~mL}$ falcon tubes. The cyanobacterial biomass was resuspended in $70 \%$ ethanol $(5 \mathrm{~mL})$ and allowed to stand at ambient temperature for $10 \mathrm{~min}$. The cyanobacteria were subsequently pelleted by centrifugation at 4,000 $\times$ g for 10 min, washed twice with sterile MLA (Bolch \& Blackburn, 1996), resuspend in MLA (5 mL), and analysed within several hours after the permeabilisation procedure.

\subsubsection{Optimisation of SYTOX Green Dye Concentration}

The SYTOX Green stock solution (1mM) was further diluted in 100\% DMSO to obtain 0.1, 0.2, $0.4,1,2,4$ and $10 \mu \mathrm{M}$ solutions of the dye. Subsamples of permeabilised cells ( $20 \mu \mathrm{L}$; see Section 2.2.2) were mixed with an equivalent volume of SYTOX Green and incubated in the dark at ambient temperature for $30 \mathrm{~min}$. This yielded final SYTOX Green concentrations of 0.05-5 $\mu \mathrm{M}$. Samples were microscopically analysed using the procedure described in Section

\subsection{6.}

\subsubsection{Optimisation of SYTOX Green Incubation time}

Ethanol-permeated cyanobacteria samples (20 $\mu \mathrm{L}$; see Section 2.2.2) were mixed with an equivalent volume of SYTOX Green $(2 \mu \mathrm{M}$; final concentration of $1 \mu \mathrm{M})$ and incubated in the dark at ambient temperature for 5, 10, 20, 30, 40 or 50 min. Samples were microscopically analysed using the procedure described in Section 2.2.6. 


\subsubsection{Testing the Accuracy of the SYTOX Green Dual-Fluorescence Cell Viability}

\section{Assay}

Samples with different fractions of lysed and intact cells were prepared to assess the accuracy of the SYTOX Green stain. For both Microcystis and Planktothrix, a subsample $(15 \mathrm{~mL})$ of each culture was transferred into a falcon tube and left untreated (intact cells), and another subsample $(15 \mathrm{~mL})$ was permeabilised according to the procedure described in Section 2.2.2 (lysed cells). From these, subsamples were mixed to obtain samples containing 0\%, 20\%, 40\%, $60 \%, 80 \%, 100 \%$ lysed cell samples $(20 \mu \mathrm{L})$. Samples were mixed with an equivalent volume of SYTOX Green ( $2 \mu \mathrm{M}$; final concentration of $1 \mu \mathrm{M})$ and incubated in the dark at ambient temperature for $30 \mathrm{~min}$, then microscopically analysed using the procedure described in Section 2.2.6.

\subsubsection{Fluorescence Microscopy Analysis}

An aliquot of the stained sample $(10 \mu \mathrm{L})$ was mounted under a coverslip on a microscope slide and sealed with nail polish. The sample was examined using an epifluorescence microscope (Olympus BX51; Tokyo, Japan) equipped with FITC (green channel) and Texas Red (red channel) fluorescence filters. The FITC filter (excitation $465-500 \mathrm{~nm}$; emission 510-545 nm) was used to detect the fluorescence of the SYTOX Green stain, and the Texas Red filter (excitation 530$575 \mathrm{~nm}$; emission 590-670 nm) was used to detect fluorescence emitted by the photosynthetic pigments present in the cells (i.e., chlorophyll- $\alpha$ and phycocyanin). The samples were analysed under 400x magnification for Planktothrix and 200x magnification for Microcystis. For each sample, ten fields of view (FOV) were observed, each composed of two fluorescence images per FOV acquired from the red and green channels using a digital camera attached to the 
microscope (Olympus DP73; Tokyo, Japan). The two images were combined using CellSens software and subsequently processed on ImageJ where each photo was converted to an 8-bit black and white image, and the threshold values were adjusted for both the red and the green channels. The Microcystis cells were counted using the "analyse particles" function. Heterotrophic bacteria $(<1 \mu \mathrm{m})$ were found in the non-axenic Microcystis cultures and were only detected under the green channel. In order to avoid this background interference, particles smaller than $2 \times 2$ pixels were excluded from the analysis. The filamentous Planktothrix strain was analysed by selecting each filament and calculating their area.

Percentage of lysed cell was calculated as follows:

$$
l=\left(\frac{a}{A}\right) \cdot 100 \%
$$

$I=$ percentage of lysed cells in the sample

$a=$ number of lysed cells counted

$A=$ total number of cells counted

\subsubsection{Half-life Evaluation of Permeabilised Cyanobacteria}

The degradation rate of lysed cells after ethanol treatment was determined according to the time elapsed before the SYTOX Green stain would no longer yield a detectable fluorescent signal under the microscope. Cultures of Microcystis aeruginosa and Planktothrix sp. (grown as 
described in Section 2.2.1) were permeabilised as described in Section 2.2.2. The cyanobacterial suspension was pelleted by centrifugation at 4,000 $\times \mathrm{g}$ for $10 \mathrm{~min}$, washed twice with sterile MLA (Bolch \& Blackburn, 1996), resuspended in sterile MLA (50 mL), and incubated at the culturing conditions described in Section 2.2.1. The initial sampling was conducted immediately after the ethanol treatment, and additional samples were taken each day for 6 days, until the SYTOX Green fluorescent signal was no longer detected microscopically.

Each day ethanol-permeated cyanobacteria samples $(20 \mu \mathrm{L})$ from each culture were incubated in the dark at ambient temperature with an equivalent volume of SYTOX Green ( $2 \mu \mathrm{M}$; final concentration of $1 \mu \mathrm{M}$ ) and microscopically analysed as described in Section 2.2.6.

\subsubsection{Image Analysis}

Analysis of concentration, incubation and half-life images was conducted in $\mathrm{R}$ using the EBImage package (Pau et al., 2010). Images were processed independently. Each image was composed of a red and a green channel, but only the green channel was analysed, as the ethanol permeabilisation process removed chlorophyll pigments and red autofluorescence was not detected. The intensity was measured as the log-transformed density of pixels that are identified as being cells. The SYTOX Green signal strength was measured by pixel density for Planktothrix, and by the number of objects detected for Microcystis. The 'makeBrush' function was used to detect the pixel density in each image, by dividing the image into two domains; pixels that are in cells, and pixels that are part of the background (of value 0). Labelled objects were pixel sets with the same unique integer value, and with the 'bwlabel' function all pixels for each connected set of foreground (non-zero) were set to a unique increasing integer. The minimum pixel value set to distinguish both Microcystis cells and Planktothrix filaments from the background was 0.05 , in order to exclude heterotrophic bacterial contamination from 
the analysis. If no cells were detected, no intensities were returned. The 'computeFeatures.basic' function was used to compute morphological features from the image and distinguish individual cell objects for Microcystis. The "agricolae" package (de Mediburu Felibe, 2019) was used to detect significant differences between groups. The "stringr" package (Wickham Hadley, 2019) was used to prepare the data for string-handling functions, which allowed all function and argument names to be consistent.

\subsubsection{Statistical Analysis}

All statistical analyses of the data were conducted in R software (R core team, 2018). Data was log-transformed and tested by one-way analysis of variance (ANOVA; PASW Statistics 18, SPSS Inc., Chicago, IL, USA) at a confidence level of 95\%. Whenever the null hypothesis of the ANOVA was rejected, differences between groups were investigated with post hoc Tukey tests.

For the accuracy assessment, a linear regression model was used to assess the relationship between the known percentage of lysed cells and the detected percentage of lysed cells. 


\subsection{RESULTS}

\subsubsection{SYTOX Green concentration}

There was no visible fluorescence of Microcystis cells using SYTOX Green at $0.05 \mu \mathrm{M}$, while the fluorescence intensity was visually similar between 0.5 and $5 \mu \mathrm{M}$ (final concentration; Fig. 2.1).

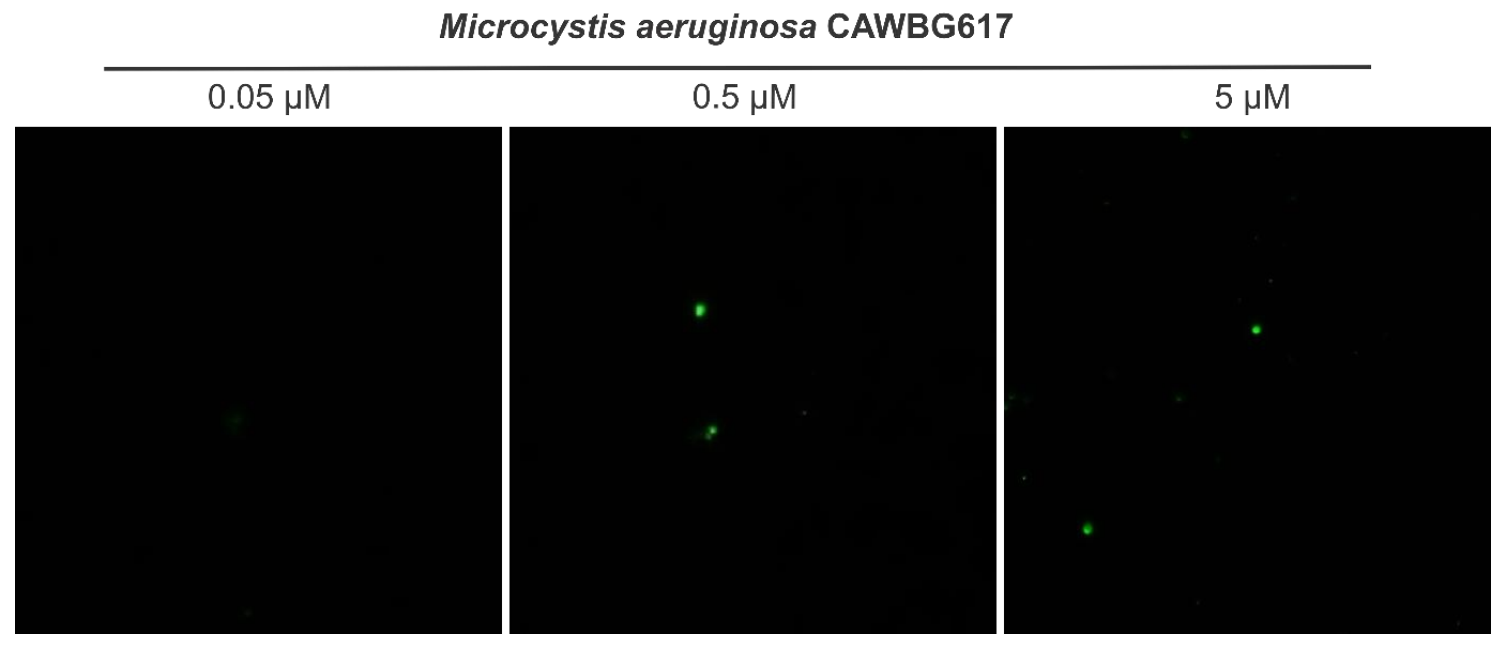

Figure 2.1 Images of lysed Microcystis cells detected under an epifluorescence microscope with a FITC filter at final concentrations of $0.05,0.5$ and $5 \mu \mathrm{M}$ SYTOX Green stain.

The difference in fluorescence intensity of SYTOX Green between concentrations was statistically significant (one-way-ANOVA, $p=0.02$ ). However, the Tukey's post hoc analysis revealed no significant differences between concentrations (Fig 2.2, $p>0.05$ ). 


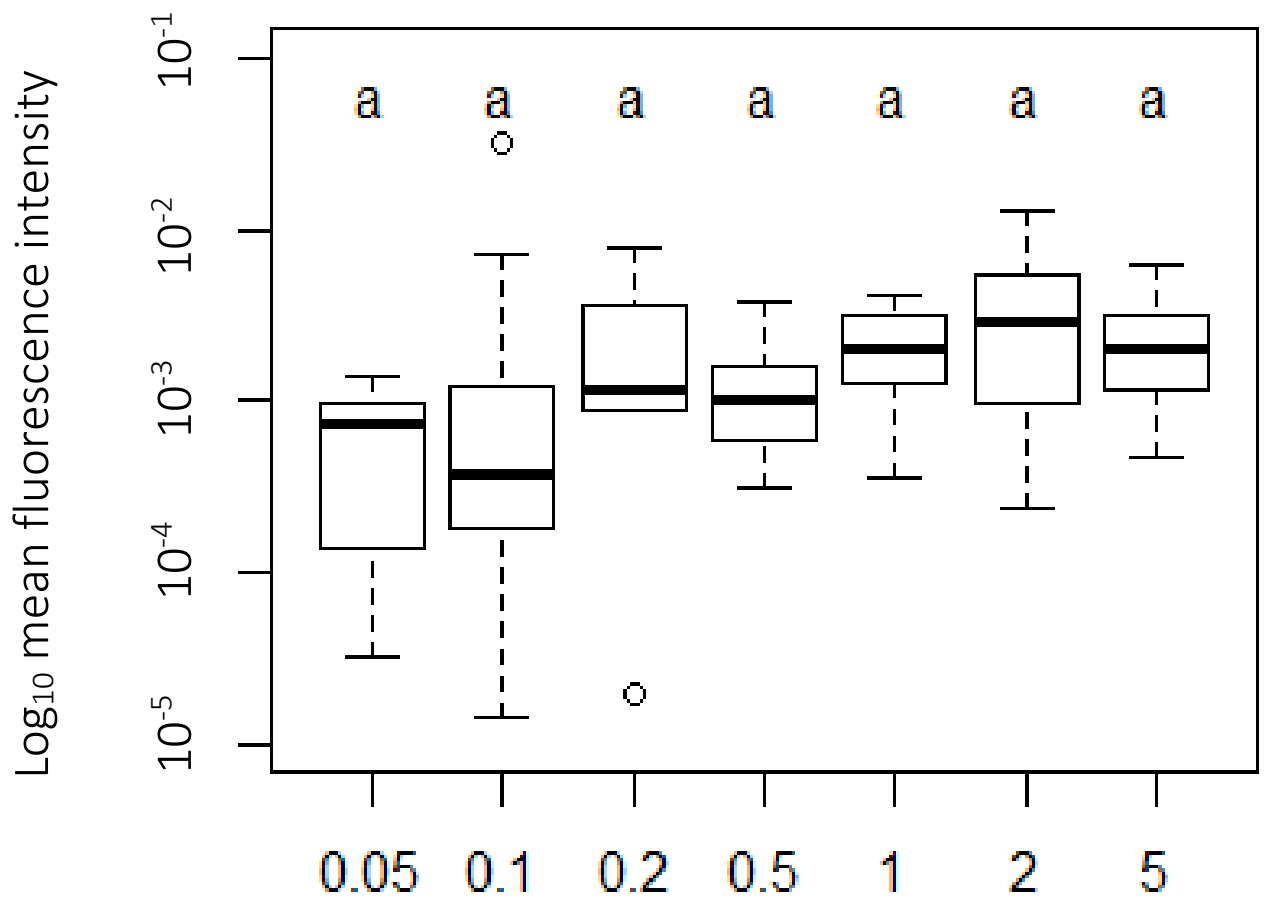

Dye concentration

Figure 2.2 Fluorescence intensity of chemically lysed samples of Microcystis at final SYTOX Green stain concentrations of $0.05,0.1,0.2,0.5,1,2$, and $5 \mu \mathrm{M}$ (note the log-scale on the $y$-axis).

No fluorescence signal was detected in the Planktothrix images at the $0.05 \mu \mathrm{M}$ concentration. Compared to Microcystis, staining with a SYTOX Green concentration of $5 \mu \mathrm{M}$ resulted in a much brighter fluorescence intensity, visibly different from the at $0.5 \mu \mathrm{M}$ images (Fig. 2.3). 
Planktothrix sp. CAWBG59

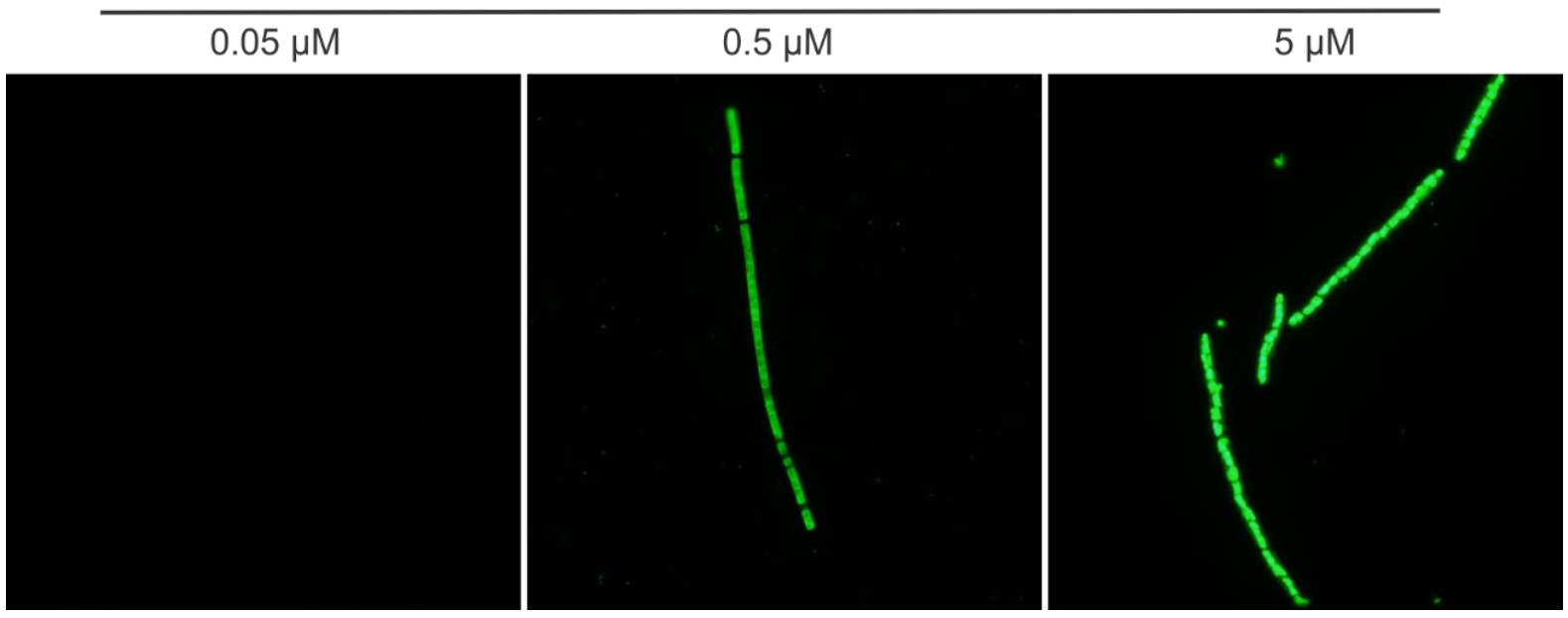

Figure 2.3 Images of lysed Planktothrix cells detected under an epifluorescence microscope with a FITC filter at concentrations of $0.05,0.5$ and $5 \mu \mathrm{M}$ SYTOX Green stain.

Varying concentrations of SYTOX Green stain resulted in four significantly different groups of fluorescence intensities for the Planktothrix strain (Fig. 2.4; one-way ANOVA, $p<0.001$ ). The intensity detected at $0.05 \mu \mathrm{M}$ was significantly lower compared to all higher concentrations (post hoc Tukey test, $\mathrm{p}<0.01$ ) except for $0.1 \mu \mathrm{M}$. Samples stained with SYTOX Green at a $5 \mu \mathrm{M}$ concentration yielded a fluorescence intensity significantly higher than all of the other concentrations $(p<0.001)$. The fluorescence intensity detected at $1 \mu \mathrm{M}$ was slightly higher than that at $0.5 \mu \mathrm{M}(\mathrm{p}=0.04)$ and was not different from that detected at $2 \mu \mathrm{M}$. 


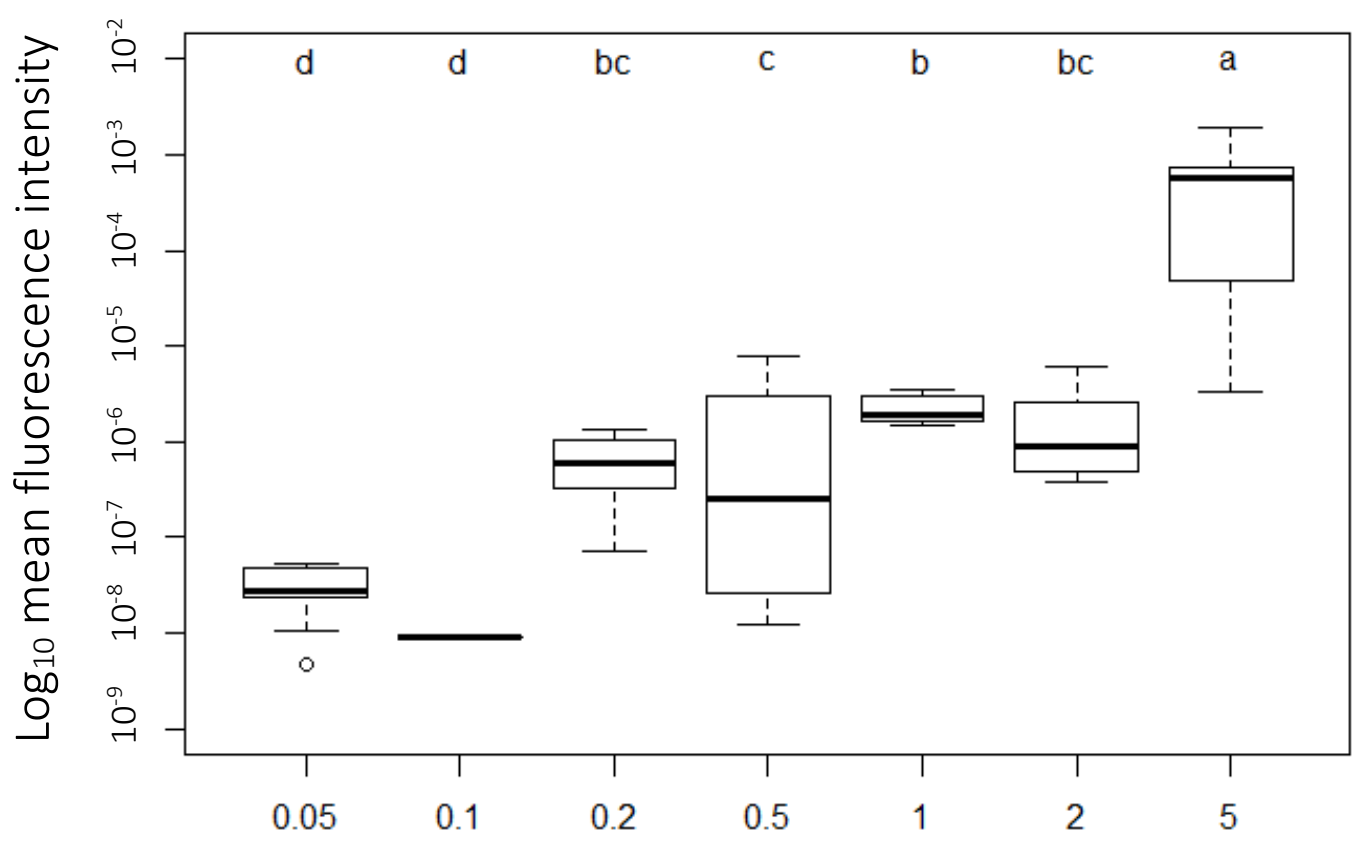

Dye concentration

Figure 2.4 Fluorescence intensity of chemically lysed samples of Planktothrix at final SYTOX Green stain concentrations of $0.05,0.1,0.2,0.5,1,2$, and $5 \mu \mathrm{M}$ (note the log-scale on the $y$-axis).

A final concentration of $1 \mu \mathrm{M}$ was chosen as the optimal staining concentration for using the SYTOX Green stain with both Microcystis and Planktothrix.

\subsubsection{SYTOX Green Incubation Time}

Longer incubation times did not visibly increase the fluorescence intensity of Microcystis cells under the microscope. Although one-way ANOVA initially revealed a significant difference in the fluorescence intensity of Microcystis lysed cells stained with SYTOX Green stain ( $1 \mu \mathrm{M}$ final concentration) after $5,10,20,30,40$, and 50 minutes $(p=0.04)$, the post hoc Tukey's analysis revealed no significant differences between time groups (Fig. 2.5-A). A significant increase in the fluorescence intensity of stained Planktothrix cells (Fig. 2.5-B) was detected between 5 and 
10 minutes (post hoc Tukey test, $p=0.01$ ) and between 5 and 40 minutes (post hoc Tukey test, $p=0.001)$, which matched observations under the microscope. Based on these results, an incubation time of 30 minutes was chosen to perform further tests with the dye for both strains. 

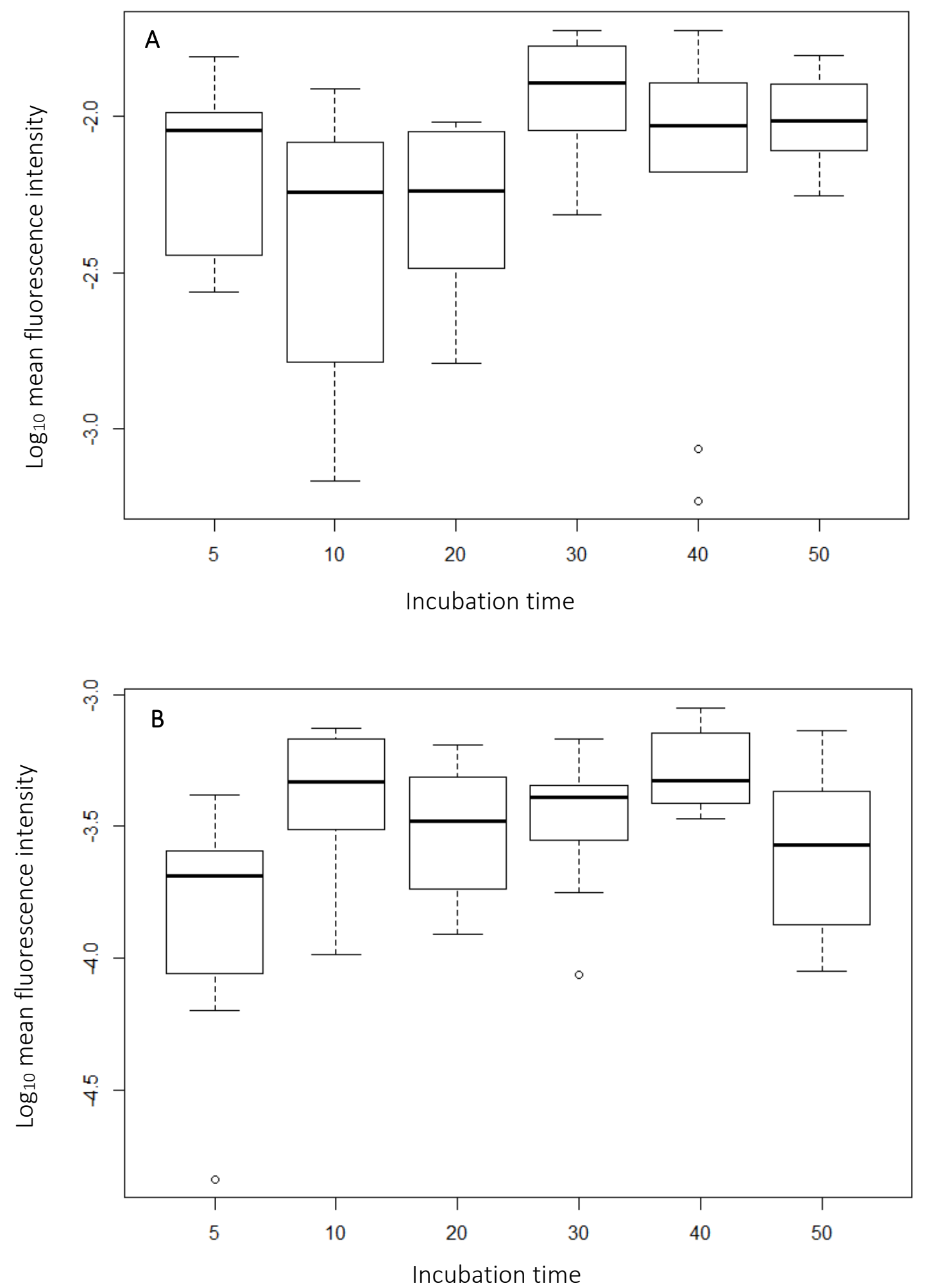

Figure 2.5 Mean fluorescence intensity of Microcystis (A) and Planktothrix (B) lysed cells after incubation in SYTOX Green stain for 5, 10, 20, 30, 40, and 50 minutes. 


\subsubsection{Accuracy of the SYTOX Green intact/lysed assay.}

To test the reliability of the optimised SYTOX Green cell viability assay, different proportions of lysed and intact cells were mixed together and analysed under the fluorescence microscope. For both Microcystis and Planktothrix there was a strong linear relationship between the percentage of lysed cells measured and the known percentage of lysed cells in the intact/lysed cell mixtures (Fig 2.6-A and B). Both relationships were significant $(p<0.001$ for Microcystis and Planktothrix), and the percentage of variance explained by the regression relationships were $97 \%$ for Microcystis $\left(R^{2}=0.97\right)$ and $98 \%$ for Planktothrix $\left(R^{2}=0.98\right)$. 

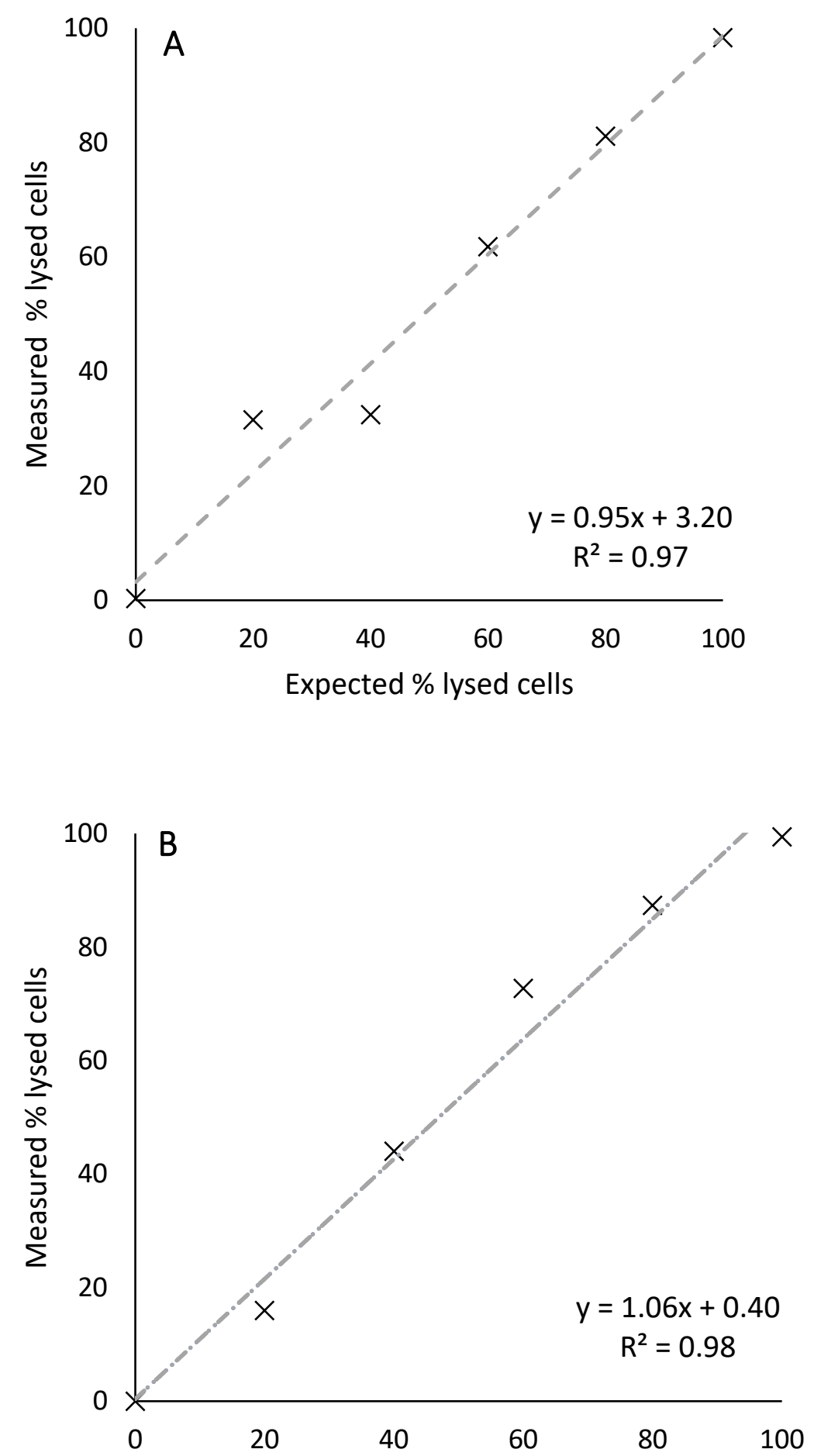

Expected \% lysed cells

Figure 2.6 Regression analysis of fluorescently detected \% lysed cells vs known \% lysis for Microcystis (A) and Planktothrix (B). 


\subsubsection{Half-life Evaluation of Permeabilised Cyanobacteria}

The half-life of Microcystis and Planktothrix cells lysed with ethanol was determined using the SYTOX Green viability assay. There was a strong and significant negative correlation between the age of ethanol-treated Microcystis cells and the percentage of cells detected over time (Fig. 2.7-A; linear regression, $R^{2}=0.96, p<0.001$ ). There was also a strong and significant negative correlation between the age of ethanol-treated Planktothrix cells and the percentage of fluorescence intensity detected (Fig. 2.7-B; linear regression, $R^{2}=0.70, p<0.001$ ). It took 1.5 days for SYTOX Green fluorescence intensity to decline by $50 \%$ in Microcystis cells $(50 \% \div$ $33 \%$ per day decrease in fluorescence intensity), while it took 2.4 days in Planktothrix $(50 \% \div$ $21 \%$ per day decrease in fluorescence intensity). 

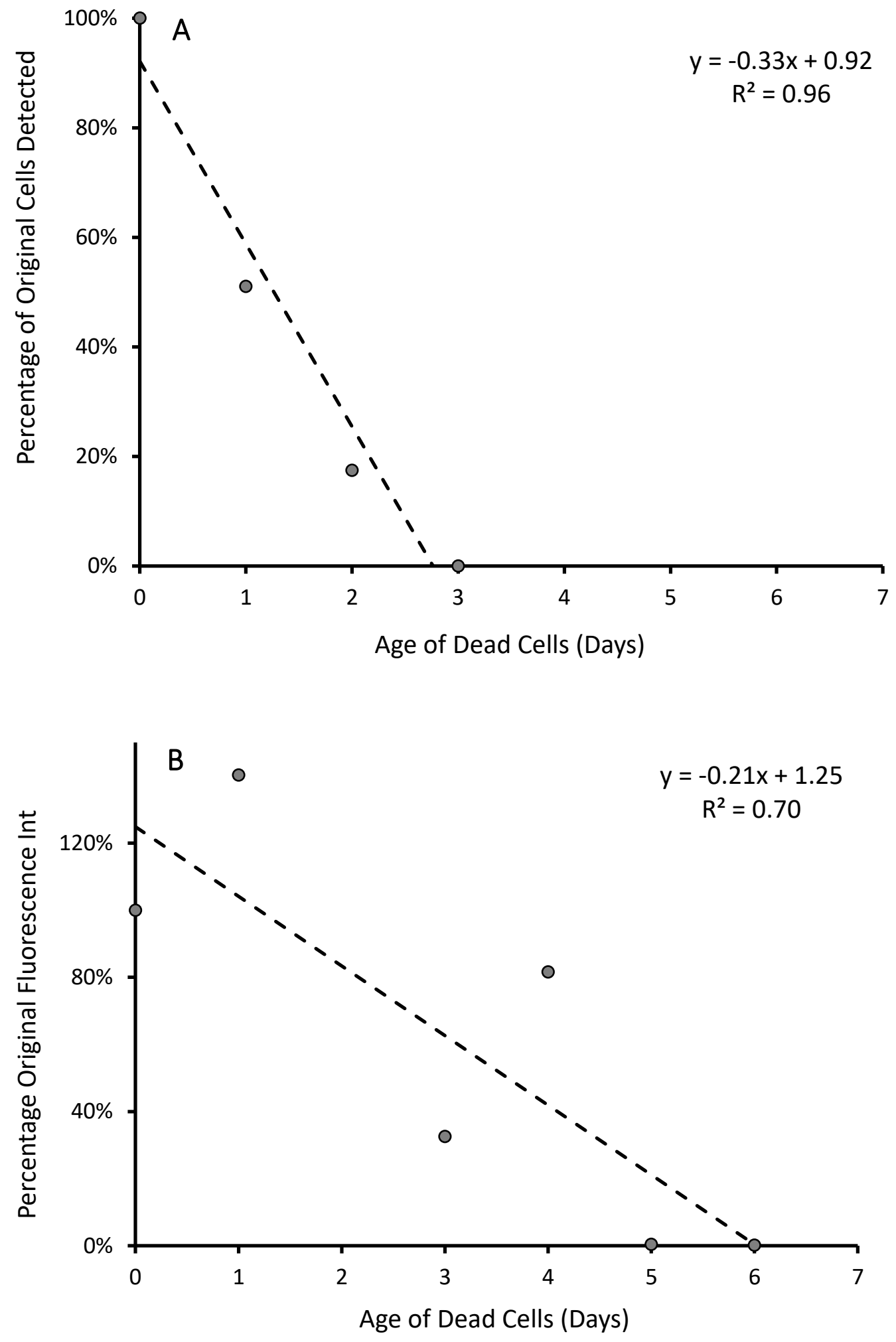

Figure 2.7 Age of Dead cells against percentage of original Microcystis cell objects detected (A) and age of dead cells against percentage of original fluorescence intensity detected in Planktothrix (B) 


\subsection{DISCUSSION}

The use of fluorochromes for physiological assessment of bacteria provides accurate information about the state of individual cells in populations (Tashyreva et al., 2013). When the viability of the plasma membrane is compromised, compounds normally excluded from the cytoplasm because of size or charge are able to penetrate cells. During the present study, the performance of the nucleic acid stain SYTOX Green was investigated as a marker for cyanobacterial cell lysis. Because excessive dye concentrations and prolonged incubation periods have previously been reported to result in heterogeneous staining of Microcoleus autumnalis cell populations (Tashyreva et al. 2013), a preliminary assessment of the performance of SYTOX Green on different cell types was conducted to improve the accuracy of the staining method.

For both Microcystis and Planktothrix samples, the minimum staining concentration needed to microscopically detect SYTOX Green fluorescence was $0.5 \mu \mathrm{M}$, although statistical analysis revealed no significant difference in fluorescence intensity between concentrations for Microcystis. This concentration is slightly higher than that needed for Microcoleus autumnalis (0.2-0.3 $\mu \mathrm{M}$; Tashyreva et al., 2013). In this study, a SYTOX Green concentration between 0.5 and $2 \mu \mathrm{M}$ resulted in the even staining of nucleoids for both strains, with a bright green fluorescence intensity that matched in intensity the red fluorescence from the photosynthetic pigments. For Planktothrix, a concentration of $5 \mu \mathrm{M}$ SYTOX Green yielded a much higher fluorescence intensity and resulted in higher background signal compared to the lower concentrations. Since the presence of nucleic acids from heterotrophic bacteria in the mucilage surrounding the filaments offers the dye more binding sites, concentrations higher than $2 \mu \mathrm{M}$ should be avoided to reduce background noise in the images. Although a bigger 
sample size may have improved the statistical significance for the differences between concentrations, a final SYTOX Green concentration of $1 \mu \mathrm{M}$ was chosen for subsequent analyses, as it yielded robust fluorescent signals for both strains used in this study.

A minimum incubation time of 5 min, as suggested by the manufacturer, yielded sufficient fluorescence signal to detect ethanol-treated Microcystis and Planktothrix cells, and no statistical differences in fluorescence intensity between different incubation times were found for Microcystis. When observed under the microscope, cells incubated for 50 min did not yield a brighter fluorescent signal compared to shorter incubation times for either strain, suggesting that if needed, cell viability samples may be analysed up to 50 min after staining without altering the reliability of the results. An incubation time of 30 min was chosen to perform sampling in Chapter 3 to maintain a safe incubation time frame, because if Microcoleus autumnalis cell populations were left for longer than 60 min in SYTOX Green, the mean percentage of stained cells increased (Tashyreva et al., 2013).

When testing the accuracy of SYTOX Green for determining the proportion of lysed to intact cells, a strong and significant positive relationship was observed for both cyanobacterial genera studied (Microcystis and Planktothrix), and the slopes were close to 1, reinforcing the accuracy of the assay. This suggests that the aforementioned heterotrophic bacterial contamination did not significantly alter the proportion of lysed cells detected in the green channel. These results supported the applicability of the dual-fluorescence assay on Microcystis cells and Planktothrix filaments in the culturing experiment described in Chapter 3, using the SYTOX Green stain as a marker for lysed cells, and cell autofluorescence as a marker for intact cells. The staining method described in this study was specifically tested on laboratory samples. Important differences in the optimal staining procedure may be encountered in natural populations, 
suggesting that further assessment of the SYTOX Green stain performance may be needed for environmental samples. For instance, $M$. autumnalis samples in the field required minimum dye concentrations 20-times higher than the laboratory samples to evenly label all cells (Tashyreva et al., 2013).

As DNA degradation occurs following the loss of cell membrane integrity, the number of dead cells determined by SYTOX Green staining may gradually decrease with time. However, a delay in the degradation of the cells may occur after membrane integrity is lost, depending on environmental conditions and species (Lebaron et al., 1998). In a culturing experiment, if the dye binds to nucleic acids of lysed cells from a previous sampling time, cell lysis counts may be overestimated. This indicates that values for the concentration of lysed cells detected using SYTOX Green may need to be adjusted according to the half-life of the lysed Microcystis and Planktothrix cells. In this study, there was a strong negative relationship between the fluorescence intensity of SYTOX Green stain and the days elapsed since cultures were ethanoltreated, as also noted by Lebaron et al. (1998). The stain had 50\% reduced efficacy after 1.5 days for Microcystis and after 2.4 days for Planktothrix. This suggests that studies with frequent sampling intervals may need to account for this SYTOX Green artifact to improve the accuracy of lysed cell counts. To the best of my knowledge, the half-life of the SYTOX Green stain has not been previously taken into account when using this dye for cyanobacterial cell viability assessment.

\subsection{CONCLUSIONS}

The efficacy and accuracy of SYTOX Green stain to measure membrane integrity in Microcystis and Planktothrix cultures was assessed. Staining with final concentrations between 0.5 and $2 \mu \mathrm{M}$ yielded sufficient fluorescence intensity to detect permeated cells, and analysing the 
samples between 5-50 minutes after staining provided reliable results. For both Microcystis and Planktothrix, the dye accurately measured lysed cells. The half-life of lysed cells was 1.5 days for Microcystis and 2.4 days for Planktothrix. This suggests that when sampling at frequent intervals, accounting for this SYTOX Green artefact would improve the accuracy of the lysed cell counts. Overall, the nucleic acid stain SYTOX Green provided an effective tool for detecting cell lysis in Microcystis and Planktothrix samples using fluorescence microscopy, supporting its use in the culturing experiment described in Chapter 3. 


\section{CHAPTER 3: INVESTIGATING THE POTENTIAL ACTIVE EXPORT OF}

\section{MICROCYSTINS IN CYANOBACTERIA}

\subsection{INTRODUCTION}

Cyanobacteria are photosynthetic prokaryotic organisms that originated 3.5 billion years ago (Omidi et al., 2017). Under favourable conditions, some cyanobacteria may proliferate to form extensive blooms, and toxin-producing species are often responsible for the poisoning of birds, fish, and mammals (including humans; Salmaso et al., 2015, Kubickova et al., 2019). The most commonly reported cyanotoxins are microcystins (MCs), which pose health risks especially to consumers that may use MC-contaminated waters as a habitat and for drinking water (Paerl et al., 2011; Buratti et al., 2017). Many morphologically different cyanobacteria can produce MCs, including; unicellular, filamentous, heterocystous and non-heterocystous genera. Microcystis, Planktothrix, Oscillatoria and Dolichospermum are among the most notable MC-producers (Huisman et al., 2018). To-date, only three cyanobacteria genera have been confirmed to be MC producers in New Zealand: Microcystis, Planktothrix and Nostoc (Puddick et al., 2019). These toxins are generally quantified in water samples and cyanobacteria extracts using liquid chromatography-mass spectrometry (LC-MS) and Adda-specific enzyme-linked immunosorbent assays (ELISA).

The various hypotheses concerning the physiological basis for $\mathrm{MC}$ production include; defence against grazers (Lürling, 2003), gene regulation (Dittmann et al., 2001); allelopathic interactions (Sukenik et al., 2002), intra-specific regulation (Schatz et al., 2007), and 
siderophoric scavenging of metals such as iron (Martin-Luna et al., 2006; Saito et al., 2008; refer to Section 1.6 for more information). Although extracellular concentrations of $M C$ have long been attributed to cell lysis (Rapala et al., 1997, Zurawell et al., 2005), most of these ecological functions, and those investigated for secondary metabolites in other bacteria and fungi, require the export of the compound from cells, under certain environmental conditions or growth stages (Dittman et al., 2001). The genetic sequence of the $\mathrm{mcyH}$ gene (part of the $M C$ synthetase operon) is similar to that of the ATP-binding cassette (ABC) genes involved in the transport of long-chain fatty acids, structurally similar to the Adda sidechain of MC. Whilst no cyanotoxin transport system has been demonstrated in cyanobacteria, MCs have been detected in the cell wall and sheath area of intact $M$. aeruginosa cells, suggesting the possible release of this toxin from intact cells (Shi et al., 1995).

Autotrophic organisms often release chemicals and toxins that negatively affect their potential competitors, generally in response to environmental changes ( $\mathrm{Li}$ and $\mathrm{Li}, 2012$ ). The role of MC as a signalling molecule, in a process known as 'quorum sensing', has received increasing attention (Borges et al., 2019). For MC to play such a role, they must first be released from the cells to the extracellular environment. Fluctuations observed in the concentrations of intraand extra-cellular MC support the hypothesis of an active release of toxins to the extracellular environment (Cordeiro-Araújo et al., 2013). The presence of toxins outside of the cell may serve as an indication of cell lysis within cyanobacteria populations, a function characteristic of intercellular signalling molecules (Schatz et al., 2007). It has also been observed that during growth, MCs are excreted partly to the surrounding media under a range of different environmental conditions (Wood et al., 2012). The significant and rapid up- and downregulation of $m c y E$ gene expression corresponding to variations in $M C$ quota, extracellular $M C$ 
levels, and cell concentrations in Lake Rotorua (New Zealand) adds further evidence to support the hypothesis that MCs may act as signalling compounds (Wood et al., 2011).

Little is known about the transport of organic substances through the cyanobacterial membrane (Stebegg et al., 2019). However, there is evidence of protein transport through the cell membrane in cyanobacteria, e.g. Synechocystis (Agarwal et al., 2018). Moreover, all gramnegative bacteria release outer membrane vesicles, which are capable of long-distance transport (Bonnington and Kuehn, 2014). Microcystin production may be regulated via circadian photosynthetic rhythms and plausibly participates in cyanobacterial central metabolism (Straub et al., 2011). For example, a three-fold increase in the levels of MC-LR in M. pinniformis was observed during the illuminated phase of light:dark treatment, and under continuous lighting in a culturing experiment, reaching a peak during the middle of the day (Bittencourt-Oliveira et al., 2005). Moreover, the levels of both intra- and extra-cellular MC oscillated significantly under both continuous light, and during a light:dark cycle (12:12h), in a different culturing experiment using $M$. aeruginosa, thus suggesting that circadian rhythms may also regulate the release of $\mathrm{MC}$ to the extracellular environment (Cordeiro-Araujo et al., 2013). However, this study (like others) lacked a means to distinguish between extracellular MCs that have been released via cell lysis, and those released via active export.

Whilst several studies have attempted to understand whether $M C$ export in cyanobacteria occurs actively or passively through cell lysis, to the best of my knowledge, the role of cell lysis as a major contributor to the observed extracellular $M C$ has not been demonstrated. During the present study, I investigated the hypothesis that cell lysis explains the concentration of extracellular MC observed in cyanobacterial cultures. A culturing experiment was conducted using two major MC-producing species, $M$. aeruginosa and Planktothrix sp., where cell lysis 
was monitored in the cultures using the SYTOX Green dual-fluorescence cell viability assay and levels of intracellular and extracellular toxins were determined by LC-MS.

\subsection{METHODS}

\subsubsection{Culture Preparation}

Autoclaved glass Erlenmeyer flasks containing sterile MLA medium $(400 \mathrm{~mL}$, Bolch \& Blackburn, 1996) were inoculated with M. aeruginosa CAWBG617 (single-celled) or Planktothrix sp. CAWBG59 (filamentous). The cultures were obtained from the Cawthron Institute Culture Collection of Microalgae (Cawthron Institute; Nelson, New Zealand). These strains were chosen as common MC-producing cyanobacteria representing two morphology types (unicellular and filamentous) with different patterns of toxin production.

Before the beginning of the toxin export experiment, the MLA medium was exchanged twice to remove toxins that had already entered the extracellular environment, whilst at the same time encouraging healthy cell growth. For Planktothrix CAWBG59, the culture was passed through plankton netting (20- $\mu \mathrm{m}$ mesh size) and the residue was diluted with a fresh sterile MLA medium $(400 \mathrm{~mL})$ in a new autoclaved Erlenmeyer flask. Since the single-celled Microcystis CAWBG617 was not retained by the plankton netting, the culture was centrifuged $\left(3,200 \times \mathrm{g}, 15 \mathrm{~min}, 18{ }^{\circ} \mathrm{C}\right)$ prior to re-suspending the cell pellet in fresh sterile MLA medium $(400 \mathrm{~mL})$ and transferring to a new flask. Three replicate cultures per strain were grown in a climate chamber at $18{ }^{\circ} \mathrm{C}$ with a $12 \mathrm{~h}: 12 \mathrm{~h}$ light:dark photoperiod and a photon-flux of $90 \mu \mathrm{mol}$ photon $\mathrm{m}^{-2} \mathrm{~s}^{-1}$. 


\subsubsection{Experimental Design and Sampling}

Each culture was grown for 57 days, with sampling occurring on days $0,3,6,9,13,16,23,37$, $44,51,57$. On each sampling day, a sample for cell enumeration $(7.5 \mathrm{~mL})$ was preserved with Lugol's iodine $(20 \mu \mathrm{L})$ and stored at ambient temperature in the dark and a sample for $\mathrm{MC}$ analysis ( $5 \mathrm{~mL}$ ) was loaded onto a glass fibre filter (Whatman GF/C, $25 \mathrm{~mm}$ diameter) using a syringe. The first $0.8 \mathrm{~mL}$ of filtrate was collected in a glass autosampler vial (extracellular $\mathrm{MC}$ sample). The GF/C filter was placed in a microcentrifuge tube (cellular MC sample) and both MC samples were stored in the freezer $\left(-20^{\circ} \mathrm{C}\right)$ until their extraction and analysis. A sample for the dual fluorescence intact/lysed assay ( $1 \mathrm{~mL}$ for Planktothrix and $20 \mu \mathrm{L}$ for Microcystis) was also collected on each sampling day and analysed immediately.

\subsubsection{Dual Fluorescence Intact/Lysed Assay}

The intact/lysed assay samples were assessed with the dual-fluorescence technique described in Chapter 2, using cyanobacterial autofluorescence from photosynthetic pigments and the nucleic acid stain SYTOX ${ }^{\circledR}$ Green. Aliquots of Planktothrix $(1 \mathrm{~mL})$ were centrifuged at $14,100 \times$ $g\left(18{ }^{\circ} \mathrm{C}\right)$ for $30 \mathrm{~min}$ in microcentrifuge tubes, $980 \mu \mathrm{L}$ of supernatant was removed, and the pellet $(20 \mu \mathrm{L})$ was resuspended and transferred to a new microcentrifuge tube. Microcystis was able to be assessed without pre-concentration by centrifugation. The cell samples were mixed with an equivalent volume of $2 \mu \mathrm{M}$ SYTOX Green (20 $\mu \mathrm{L}$; final dye concentration of 1 $\mu \mathrm{M})$ and incubated in the dark at room temperature for $30 \mathrm{~min}$. An aliquot of the stained sample $(10 \mu \mathrm{L})$ was mounted onto a microscope slide, sealed with nail polish and examined under an epifluorescent microscope (Olympus BX51, Tokyo, Japan) equipped with FITC and Texas Red fluorescence filters. 
The FITC filter (excitation 465-500 nm; emission 510-545 nm, green channel) was used to detect the SYTOX Green fluorescence and the Texas Red filter (excitation 530-575 nm; emission 590-670 nm, red channel) was used to detect the autofluorescence emitted by the photosynthetic pigments present in the cells (i.e., chlorophyll- $\alpha$ and phycocyanin). The samples were analysed under 400x magnification for Planktothrix and 200x magnification for Microcystis. For each sample, ten fields of view (FOV) were observed, with each of these comprising two fluorescence images per FOV, acquired in the red and green channels, using a digital camera attached to the microscope (Olympus DP73, Tokyo, Japan).

The images were combined using CellSens software and subsequently processed with ImageJ, where each photo was converted to an 8-bit black and white image, and the threshold values were adjusted for both the red and the green channels. The Microcystis cells were counted using the "analyse particles" function. Heterotrophic bacteria $(<1 \mu \mathrm{m})$ were found in the nonaxenic Microcystis cultures and were detected in the green channel only. In order to avoid this background interference, particles smaller than $2 \times 2$ pixels were excluded from the analysis. The filamentous Planktothrix strain was analysed by selecting each of the filaments and then calculating their surface area.

The percentage of lysed cells was calculated as follows:

$$
l=\left(\frac{a}{A}\right) \cdot 100 \%
$$

where:

$I=$ percentage of lysed cells in the sample

$a=$ number of lysed cells counted

$A=$ total number of cells counted 


\subsubsection{Cell Enumeration}

An aliquot of each cell count sample $(0.5-2 \mathrm{~mL})$ was settled in 12-well plates (Corning Constar) with milli-Q water, so that each well contained a total volume of $4 \mathrm{~mL}$. The volume to be settled and the dilution factor were adjusted in order to have between 20 and 60 cells per FOV for the Microcystis, and between 5 and 20 filaments per FOV for the Planktothrix. Cell enumeration was performed with an inverted microscope (Olympus CKX41) using 10 FOVs per sample. Microcystis samples were assessed at 800x magnification and cell counts were obtained using a manual differential counter. Cell concentrations for Microcystis samples were determined as follows:

$$
N=\frac{S / b \cdot n \cdot f}{V}
$$

where:

$N=$ cell concentration in the culture (cells $\mathrm{mL}^{-1}$ )

$n=$ average of number of cells counted in 10 FOVs

$S=$ total surface area of the bottom of the settling chamber $\left(\mathrm{mm}^{2}\right)$

$b=$ FOV area $\left(\mathrm{mm}^{2}\right)$

$f=$ dilution factor

$V=$ volume of sample settled $(\mathrm{mL})$

The Planktothrix cell count samples were mechanically ground prior to microscopic observations, using a mortar and pestle to disperse amalgamations into individual filaments. Cell enumeration was carried out by measuring the length of all filaments in ten FOVs, using 
the polyline tool on CellSens with an inverted microscope (Olympus CKX41) at 400x magnification. The total length of filaments in ten FOVs was divided by ten to yield an average filament length per FOV. The number of cells per FOV was calculated by dividing the average filament length per FOV by the average cell length. The proportion of the well surface observed in one FOV, any sample dilutions and the volume settled were then used to determine the cell concentration using the formula below. To determine the average Planktothrix CAWBG59 cell length, a light microscope (Olympus BX51) attached to a digital microscope camera (Olympus DP70) was used to measure the length of 50 Planktothrix cells (randomly chosen from at least 10 different filaments) at 1,000× magnification.

Cell concentrations for Planktothrix were calculated as follows:

$$
N=\frac{\frac{S}{b} \cdot \frac{P}{p} \cdot f}{V}
$$

where:

$N=$ cell concentration in the culture (cells $\mathrm{mL}^{-1}$ )

$P=$ total length of Planktothrix filaments per FOV $(\mu \mathrm{m})$

$p=$ average Planktothrix cell length $(\mu \mathrm{m})$

$S=$ total surface area of the bottom of the settling chamber $\left(\mathrm{mm}^{2}\right)$

$b=$ FOV area $\left(\mathrm{mm}^{2}\right)$

$f=$ dilution factor

$V=$ volume of settled sample $(\mathrm{mL})$ 
The concentration of lysed cells was calculated as follows:

$$
L=N \cdot\left(\frac{l}{100}\right)
$$

where:

$L=$ Concentration of lysed cells (lysed cells $\mathrm{mL}^{-1}$ )

$N=$ Cell concentration (cells $\mathrm{mL}^{-1}$ )

$I=$ Percentage of lysed cells in the sample

\subsubsection{Microcystin Analysis}

The cellular MC samples were extracted by adding $80 \%$ methanol $+0.1 \%$ formic acid $(v / v ; 1$ $\mathrm{mL}$ ) to each microcentrifuge tube containing the GF/C filter loaded with a sample. The tubes were sonicated in a bath sonicator (60 min, $53 \mathrm{KHz}, 100 \%$ power) filled with water and ice. The toxin extracts were clarified by centrifugation $\left(12,000 \times g ; 5 \mathrm{~min}, 18{ }^{\circ} \mathrm{C}\right)$ and the extract supernatant $(0.8 \mathrm{~mL})$ was transferred into a glass autosampler vial and stored in the freezer ($20{ }^{\circ} \mathrm{C}$ ) until analysis. The extracellular samples did not require any further preparation. Microcystin concentrations were determined by liquid chromatography-tandem mass spectrometry (LC-MS/MS). The compounds were separated in an Acquity I-Class ultraperformance liquid chromatography system (Waters Co.), using a $\mathrm{C}_{18}$ column (Waters Acquity $\mathrm{BEH}-\mathrm{C}_{18}, 1.7-\mu \mathrm{m}, 50 \times 2.1 \mathrm{~mm}$ ) maintained at $40^{\circ} \mathrm{C}$ in a column oven. The sample components were eluted using a flow rate of $0.4 \mathrm{~mL} \mathrm{~min}^{-1}$ and a gradient of $10 \%$ acetonitrile (mobile phase A) to $90 \%$ acetonitrile (mobile phase B), each containing $100 \mathrm{mM}$ formic acid and $4 \mathrm{mM}$ ammonia as described in Table 3.1. 
Table 3.1 Liquid chromatography gradient for microcystin quantitation by LC-MS.

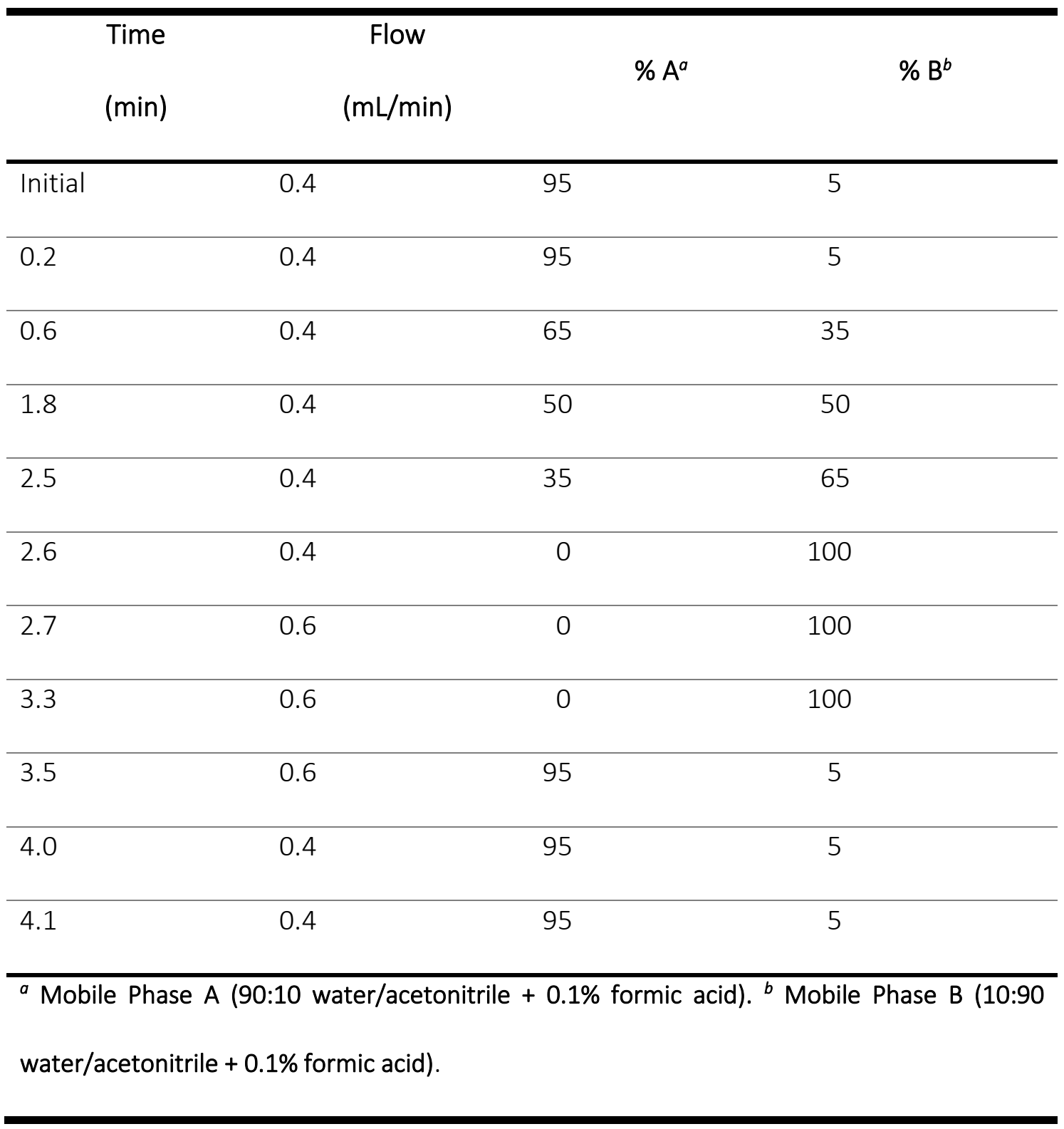

The sample components were analysed on a Xevo-TQS mass spectrometer (Waters Co.) operated in positive-ion electrospray ionization mode (source temperature $150{ }^{\circ} \mathrm{C}$; capillary voltage $1.5 \mathrm{kV}$; $\mathrm{N}$ desolvation gas $1,000 \mathrm{~L} \mathrm{~h}^{-1}$ at $500{ }^{\circ} \mathrm{C}$; cone gas $150 \mathrm{~L} \mathrm{~h}^{-1}$ ). Multiple reaction monitoring (MRM) channels that assessed the $\mathrm{m} / \mathrm{z} 135$ fragment ion from the protonated molecular cations were used to quantify each toxin $\left([\mathrm{M}+2 \mathrm{H}]^{2+}\right.$ for $\mathrm{MC}-\mathrm{RR}$ and associated 
variants; $[\mathrm{M}+\mathrm{H}]^{+}$for the other MCs). The MRM conditions for each $M C$ congener that was assessed are summarised in Table 2.

Table 3.2. Multiple reaction monitoring conditions for liquid chromatography.

\begin{tabular}{|c|c|c|c|c|}
\hline Microcystin (MC) & $\begin{array}{l}\text { Parent ion } \\
\qquad(\mathrm{m} / \mathrm{z})\end{array}$ & $\begin{array}{l}\text { Daughter ion } \\
\qquad(\mathrm{m} / \mathrm{z})\end{array}$ & $\begin{array}{c}\text { Cone Voltage } \\
\text { (V) }\end{array}$ & $\begin{array}{c}\text { Collision Energy } \\
\text { (eV) }\end{array}$ \\
\hline didesmethylMC-RR & 505.70 & 135.1 & 40 & 27 \\
\hline desmethylMC-RR & 512.70 & 135.1 & 40 & 27 \\
\hline MC-RR & 519.70 & 135.1 & 40 & 27 \\
\hline MC-AR / MC-RA & 953.60 & 135.1 & 40 & 65 \\
\hline $\begin{array}{l}\text { didesmethylMC-LR/MC- } \\
\text { RAba }\end{array}$ & 967.70 & 135.1 & 40 & 65 \\
\hline desmethylMC-LR & 981.65 & 135.1 & 40 & 65 \\
\hline MC-LR & 995.70 & 135.1 & 40 & 65 \\
\hline MC-FR & 1029.70 & 135.1 & 40 & 65 \\
\hline MC-YR & 1045.70 & 135.1 & 40 & 70 \\
\hline MC-WR & 1068.75 & 135.1 & 40 & 65 \\
\hline
\end{tabular}


Primary standards of MC-RR, MC-YR and MC-LR (DHI Lab Products) were used to produce external calibration curves (2-100 $\left.\mathrm{ng} \mathrm{mL}^{-1}\right)$ and to quantify the $\mathrm{MC}$ congeners observed in the samples. The MC-YR and MC-RR congeners were calibrated using the MC-YR and MC-RR calibration curves, respectively. The MC-LR calibration curve was used to quantify the other congeners. To ensure that $\mathrm{MC}$ concentrations were within the linear response of the method, samples lying outside the standard curve $\left(>100 \mathrm{ng} \mathrm{mL}^{-1}\right.$ ) were diluted (either $1 / 20$ or $1 / 50$ ) in $50 \% \mathrm{MeOH}$ and re-analysed.

The MC quota is the amount of $M C$ in each individual cell. This was calculated for both strains by dividing the cellular MC concentration by the concentration of cells in the sample:

$$
M C_{q}=\frac{C M}{C}
$$

where:

$M C_{q}=M C$ cell quota $\left(\mathrm{ng}\right.$ cell $\left.{ }^{-1}\right)$

$C M=$ Cellular $M C$ concentration ( $\mathrm{ng} \mathrm{mL}^{-1}$ )

$C=$ Cell concentration (cells $\mathrm{mL}^{-1}$ )

At times, the MC quota was converted to $\mathrm{pg}^{\mathrm{N}}$ cell ${ }^{-1}$ by multiplying by 1,000 . 


\subsubsection{Prediction of Extracellular MC Concentration Using Lysed Cell Concentration}

The lysed cells' contribution of MCs to the extracellular environment was calculated as follows:

$$
M C_{l}=M C_{q} \times L
$$

where:

$M C_{l}=$ concentration of extracellular $M C$ from lysed cells $\left(\mathrm{ng} \mathrm{mL} \mathrm{L}^{-1}\right)$

$M C_{q}=M C$ quota $($ ng cell-1)

$L \quad=$ Concentration of lysed cells in the culture (lysed cells $\mathrm{mL}^{-1}$ )

An adjustment was made for the concentration of lysed cells, using the half-lives of lysed cells determined for Microcystis and Planktothrix described in Chapter 2. The number of lysed cells that remained detected in the cultures was calculated as follows:

$$
E=L \times\left(0.5^{\frac{T L}{H L}}\right)
$$

where:

$E=$ Excess number of lysed cells detected

$L=$ Concentration of lysed cells in the culture (lysed cells $\mathrm{mL}^{-1}$ )

$T L=$ Time lapse between sampling days

$H L=$ SYTOX Green stain half-life (1.5 days for Microcystis CAWBG617 and 2.4 days for Planktothrix CAWBG59; see Section 2.2.7) 
The surplus number of lysed cells was then subtracted from the original lysed cell concentration, to obtain a more accurate estimation of the concentration of lysed cells in the sample.

\subsubsection{Statistical Analyses}

All statistical analyses of the data were performed with R software (R core team, 2018). The influence of sampling time on the proportion of lysed cells, cell concentrations, and extracellular MC concentration were tested by one-way analysis of variance (ANOVA; PASW Statistics 18, SPSS Inc., Chicago, IL, USA), at a confidence level of 95\%. Whenever the null hypothesis of the ANOVA was rejected, differences between groups were investigated with post hoc Tukey tests. Most of the data did not pass the normality and variance homogeneity Levene test and, therefore, was log-transformed prior to statistical analysis. A linear regression model was used to assess the relationship between the predicted extracellular MC contributed by the lysed cells and the observed extracellular MC concentration. The data in all graphs are represented as mean values \pm standard error. 


\subsection{RESULTS}

Cultures of Microcystis aeruginosa and Planktothrix sp. were monitored over 57 days. During this time, samples for cell enumeration, toxin concentration and an intact/lysed cell assay were collected and analysed. The SYTOX Green nucleic acid stain successfully stained the lysed cells from both cultures, emitting a bright green fluorescence that could easily be differentiated from the red fluorescence of chlorophyll-rich, healthy cells (Fig. 3.1).
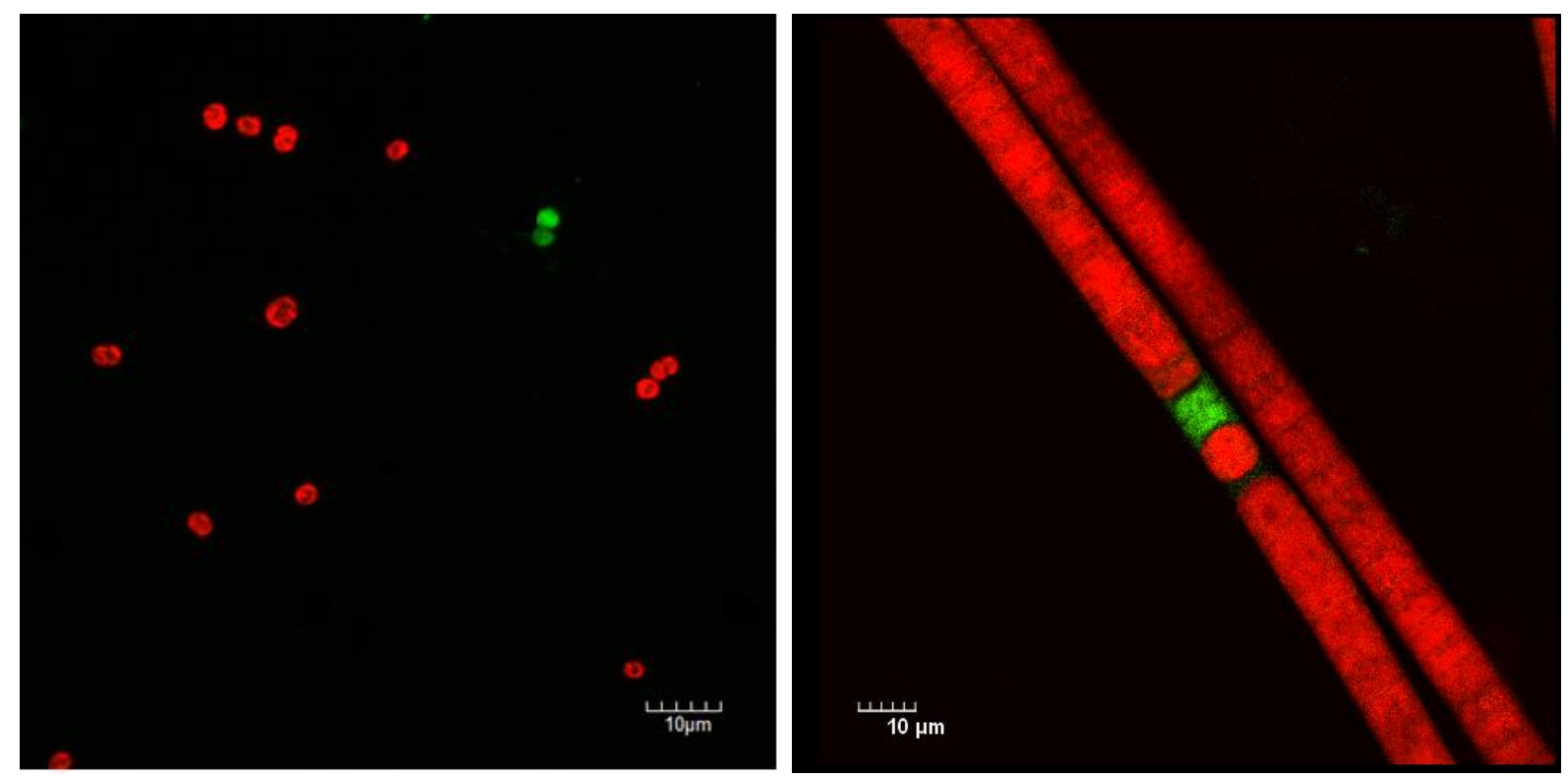

Figure 3.1 Confocal microscopy images of Microcystis (left) and Planktothrix (right) samples stained using SYTOX Green stain. Red fluorescence indicates cells with intact cell membranes; green fluorescence shows SYTOX Green permeated cells; Scale bar $=10 \mu \mathrm{m}$.

\subsubsection{Microcystis Culturing Experiment}

Culture density and MC quota increased throughout the experiment (one-way ANOVA, $p<0.001)$. The Microcystis culture concentrations increased by over 3 times from $7 \times 10^{6}$ cells $\mathrm{mL}^{-1}$ to $25 \times 10^{6}$ cells $\mathrm{mL}^{-1}$ (Fig. 3.2). During this time, the MC quota increased by 2.3 -times, 
from $0.03 \mathrm{pg} \mathrm{cell}^{-1}$ at the start of the experiment to $0.07 \mathrm{pg} \mathrm{cell}^{-1}$ on the final sampling day ( $\mathrm{p}$ $=0.008$ ). The MC quota peaked at $0.11 \mathrm{pg} \mathrm{cell}^{-1}$ on day 51 (Fig. 3.2).

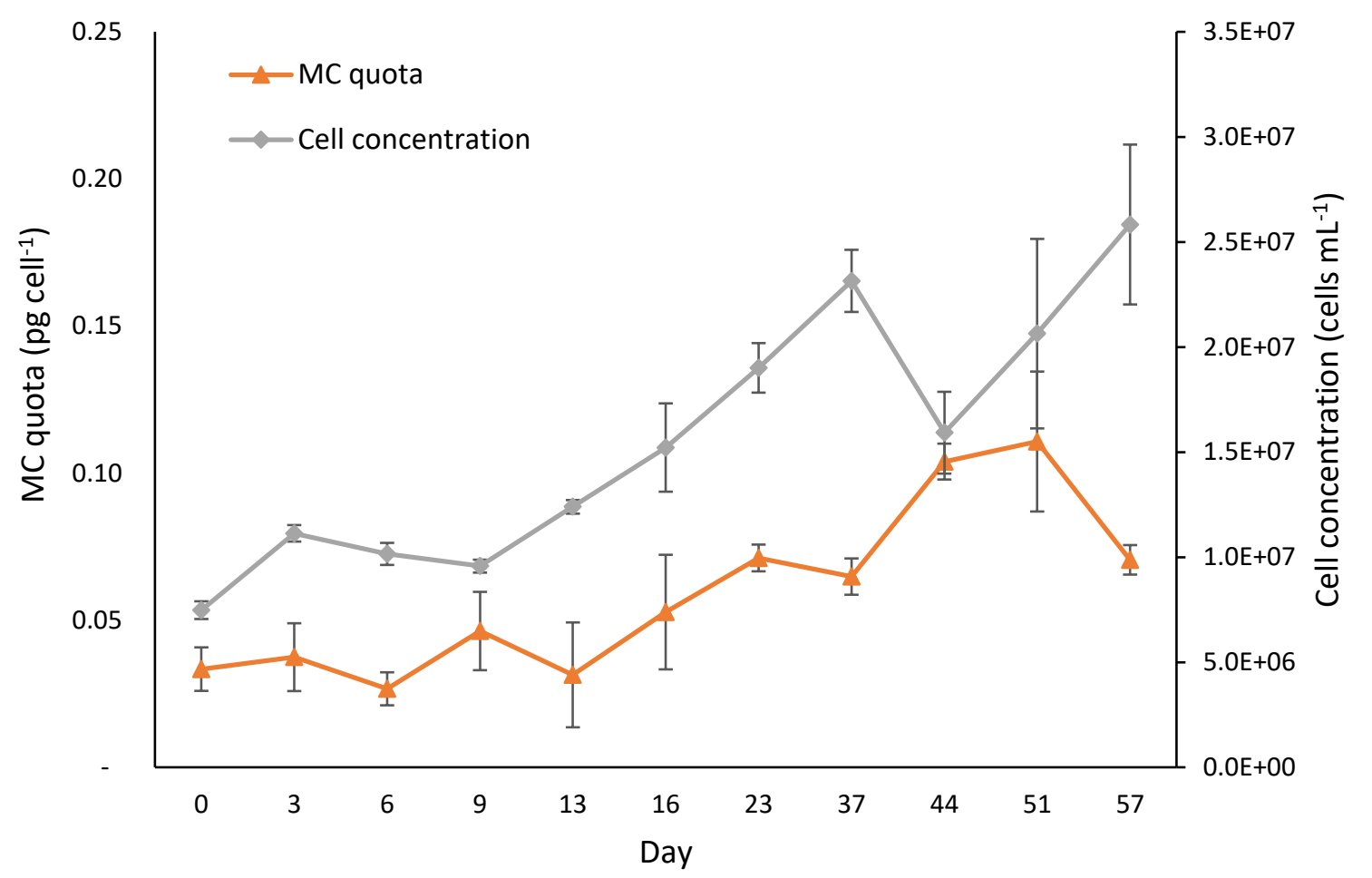

Figure 3.2 Time series of cell concentration and microcystin (MC) quota in the Microcystis culture over the 57 day sampling period. Data correspond to mean \pm one standard error, $\mathrm{n}=3$.

There was a significant increase in the proportion of lysed cells occurred during the experiment (one-way ANOVA, $p=0.002$ ). The percentage of lysed cells increased from $4 \%$ on the first day to $17 \%$ on the final day (Fig. 3.3). A post hoc Tukey test revealed that the proportion of lysed cells were significantly different between days 6 and $51(p=0.03)$, and days 13 and 51 $(p=0.03)$. The concentration of extracellular MCs also increased significantly during the experiment $(p<0.001)$, reaching a concentration of $196 \mathrm{ng} \mathrm{mL}-1$ on the final sampling day 
(Fig. 3.3-A). The first significant increase in extracellular $M C$ since the beginning of the experiment (day 0) occurred on day $9(p<0.001)$. The next significant increase occurred between days 9 and $23(p=0.015)$, then between days 23 and $37(p=0.004)$, and the last significant increase occurred between days 37 and $51(p=0.002)$. At many of the sampling points there was a very low variability in extracellular $M C$ between cultures (i.e., days 0, 3, 9, $13,16,23)$. There was a strong and significant correlation between the concentration of lysed cells in the Microcystis cultures and the concentration of extracellular $M C\left(R^{2}=0.52, p<0.001\right.$; Fig. 3.3-B). 


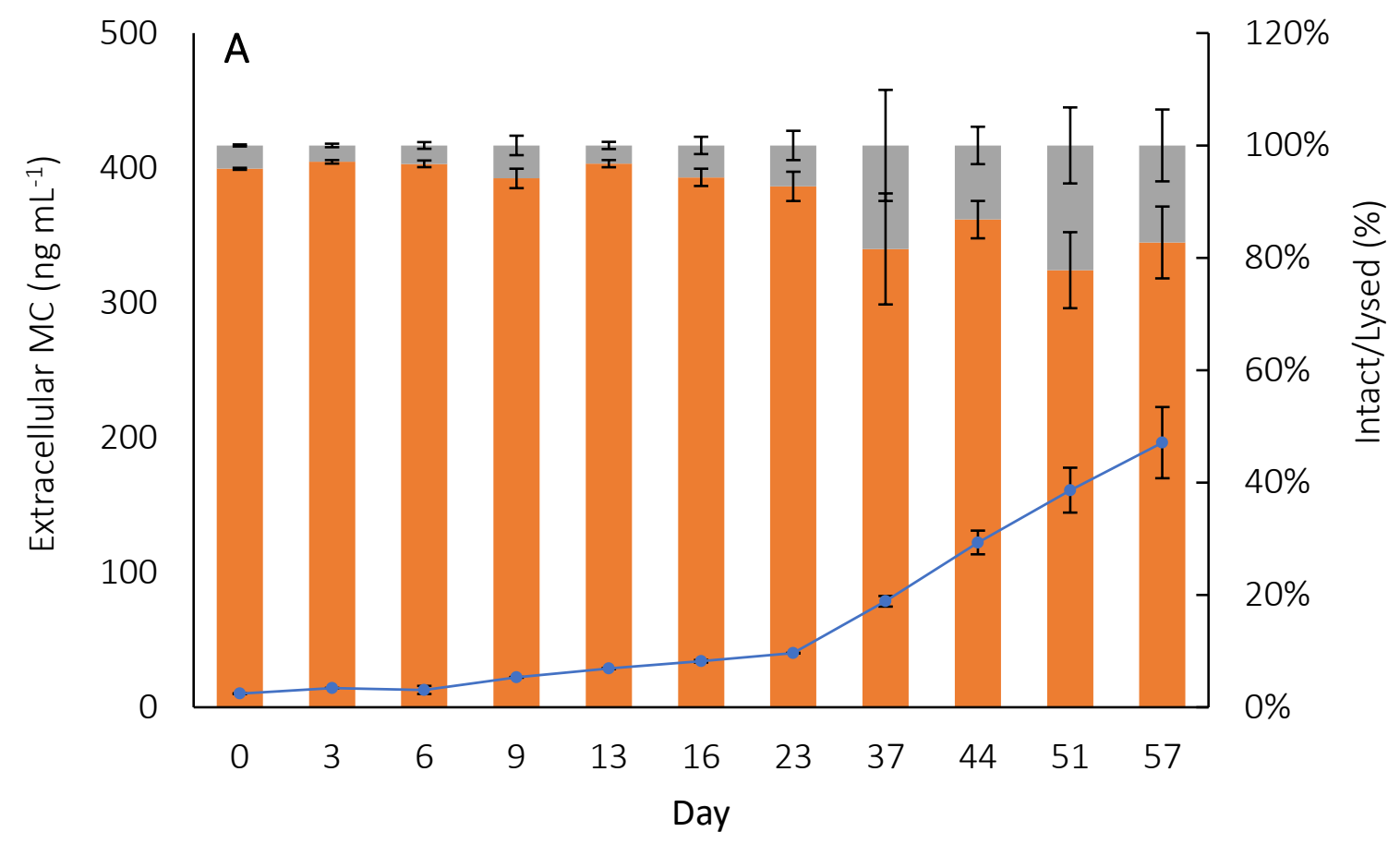

\% Intact $\quad \%$ Lysed $\rightarrow$ Extracellular MC

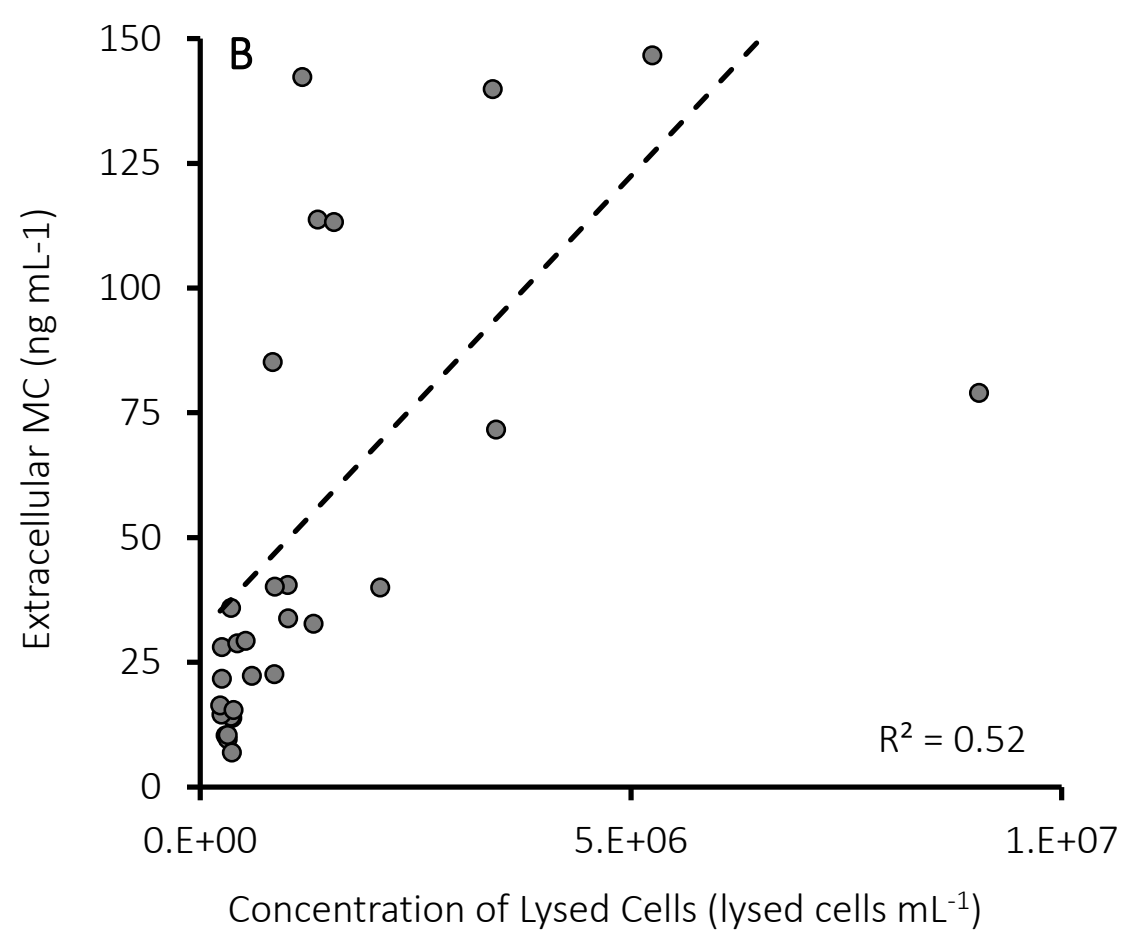

Figure 3.3 Time series of the concentration of extracellular microcystins (MCs) and the proportion of lysed and intact cells in the Microcystis cultures (A) and concentration of extracellular MC as a function of the concentration of lysed Microcystis cells (B). 
To further investigate the significant relationship between cell lysis and extracellular MC, a model was developed to predict the concentration of extracellular $M C$ in the culture medium from the Microcystis cell lysis data (see Section 3.2.6 for more details). When the predicted extracellular MC was compared to the extracellular MC measured in the cultures, a strong and significant relationship was observed $\left(R^{2}=0.55, p<0.001\right.$, Fig. 3.4-A). However, the gradient of the linear regression showed that the concentration of extracellular MC was overestimated by a factor of 2.6. When the model was adjusted to compensate for excess signals from lysed cells that had not degraded between sampling points (using the half-life for Microcystis cells determined in Section 2.2.7), the strength and accuracy of the model was not substantially improved $\left(R^{2}=0.50, p<0.001 ;\right.$ gradient $=2.48$ vs. 2.59; Fig. 3.4-B $)$. 

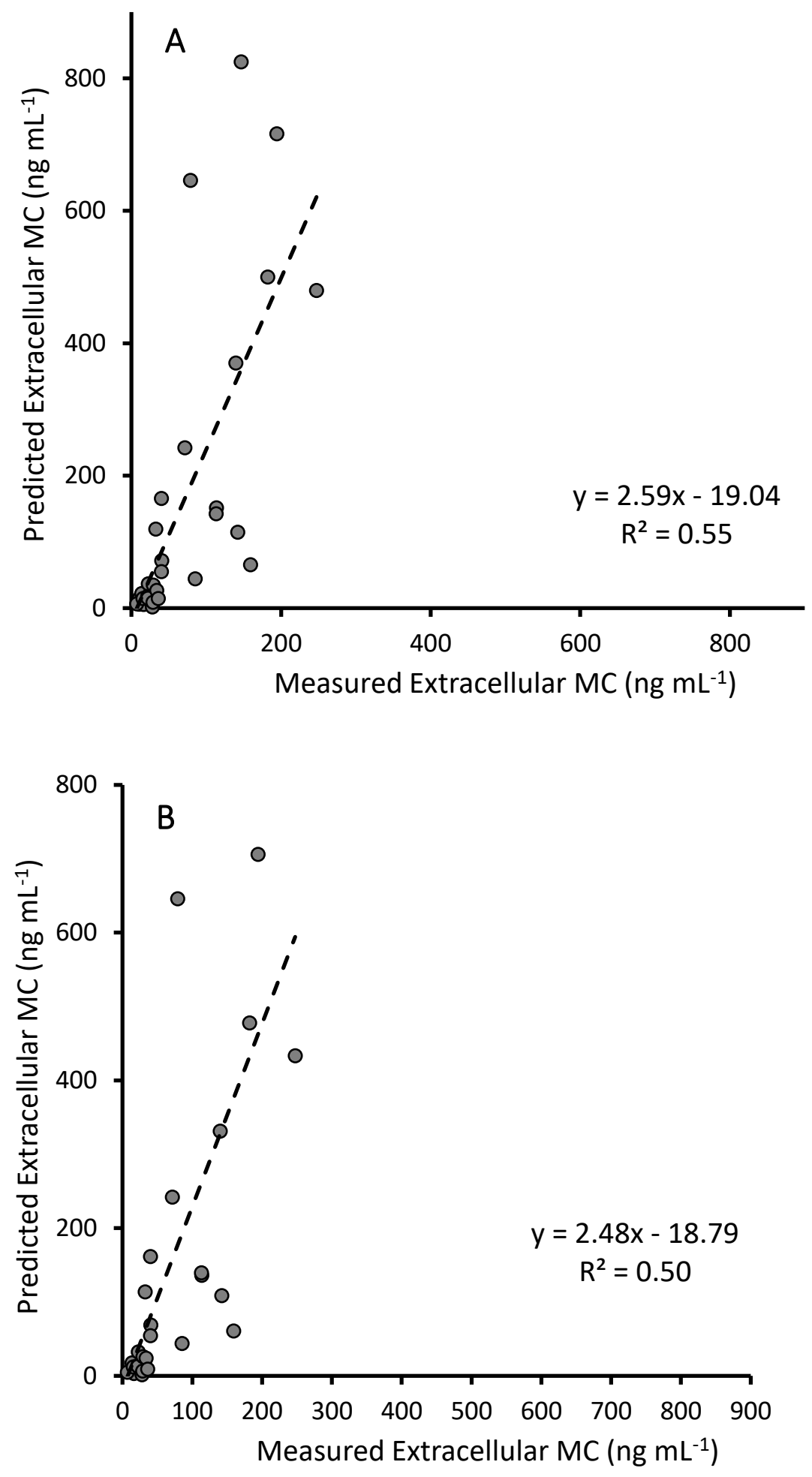

Figure 3.4 Predictive model for the contribution to extracellular microcystins (MCs) from lysed Microcystis cells: without adjustment for excess lysed cells (A); with adjustment for excess lysed cells (B). 


\subsubsection{Planktothrix Culturing Experiment}

Planktothrix cultures also significantly increased in density (one-way ANOVA, $p<0.001$ ) and MC quota (one-way ANOVA, p < 0.001) throughout the experiment (Fig. 3.5). The cultures grew from $1 \times 10^{3}$ cells $\mathrm{mL}^{-1}$ to $28 \times 10^{3}$ cells $\mathrm{mL}^{-1}$ on the final sampling day, and $\mathrm{MC}$ quotas increased by 6 -times, from $0.02 \mathrm{pg} \mathrm{cell}^{-1}$ on day 0 , to $0.12 \mathrm{pg} \mathrm{cell}^{-1}$ on the last sampling day, peaking at $0.17 \mathrm{pg} \mathrm{cell}^{-1}$ on day 51 (Fig. 3.5). There was a 7.8-fold increase in MC quota between day 13 and day 23 (from $0.001 \mathrm{pg}$ cell $^{-1}$ to $0.088 \mathrm{pg} \mathrm{cell}^{-1} ; \mathrm{p}=0.025$ ), and a 2.5 -fold increase between day 44 and 51 (from 0.07 pg cell $^{-1}$ to 0.17 pg cell $^{-1} ; p=0.021$ ).

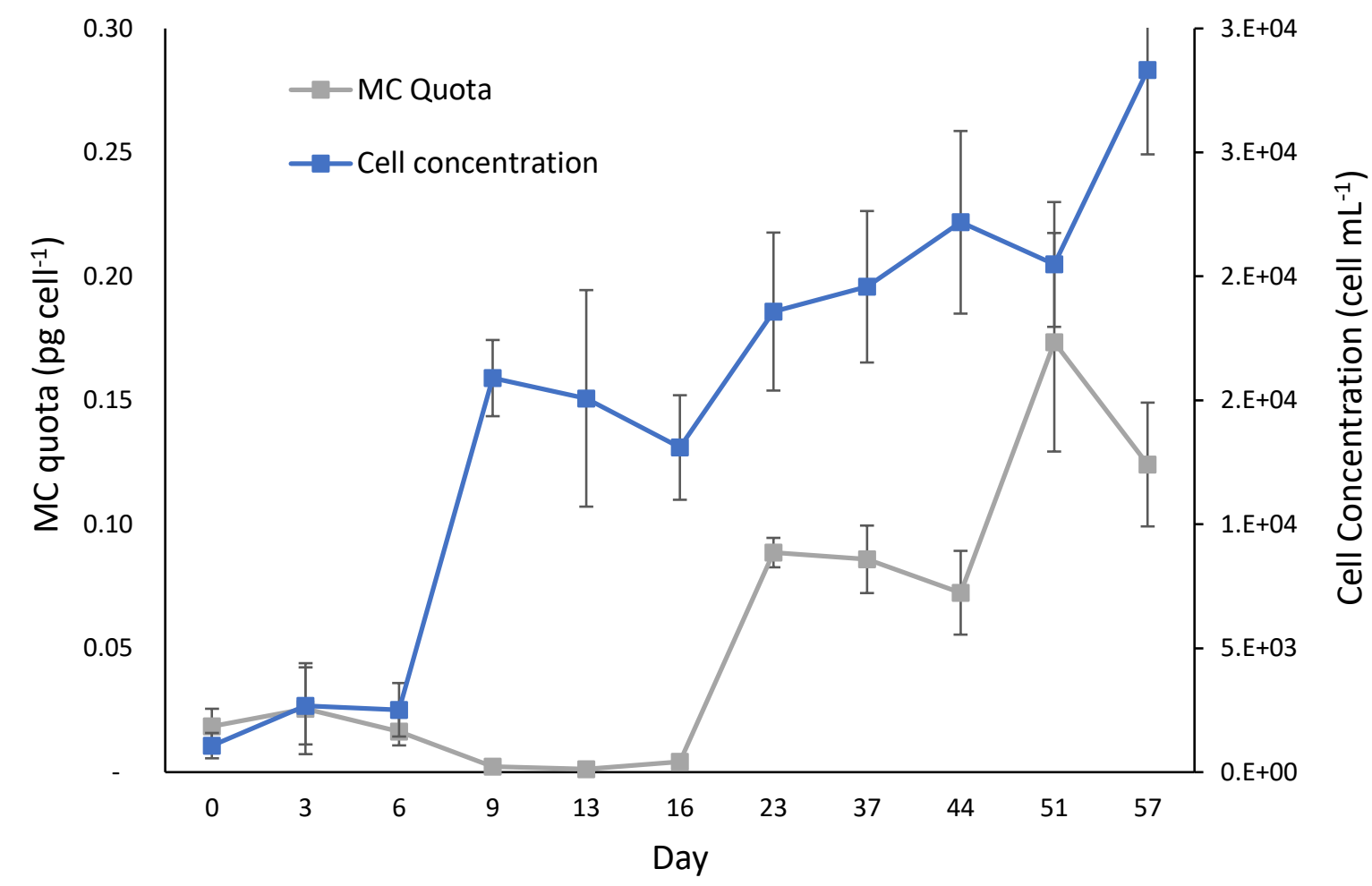

Figure 3.5 Time series of cell concentration and microcystin (MC) quota in the Planktothrix cultures over the sampling period. The datapoints correspond to the mean \pm one standard error, $n=3$.

There was a significant increase in the proportion of lysed cells in the Planktothrix cultures during the experiment (Fig. 3.6-A; one-way ANOVA, $p<0.001$ ). While almost no cell lysis was 
detected at the beginning of the experiment, by the final sampling day (day 57), an average of $37 \%$ of the Planktothrix cells had been lysed. Although a post hoc Tukey test revealed a significant drop in the proportion of intact cells between days 13 and 16 ( $p=0.002$ ), this proportion remained relatively constant until another statistically significant increase in cell lysis occurred between day 44 and day $57(p<0.001)$. During the experiment, there was a significant increase in the extracellular MC concentrations (one-way ANOVA, $p<0.001$ ), which rose from $2.2 \mathrm{ng} \mathrm{mL}^{-1}$ on day 0 to $103.3 \mathrm{ng} \mathrm{mL}^{-1}$ on day 57 (Fig. 3.6-A). The highest extracellular MC concentration of $113 \mathrm{ng} \mathrm{mL}^{-1}$ was detected on day 44, but the concentration did not drop significantly thereafter (post hoc Tukey test, $p=0.999$ ). As with the Microcystis cultures, at many of the sampling points the variations in extracellular MC between cultures (i.e., on days $0,3,6,9,16,23,37)$ were very low. There was a weak but significant relationship between the concentration of lysed Planktothrix cells and the extracellular MC concentration, with only $10 \%$ of the variance explained by the linear regression $\left(R^{2}=0.10, p=0.006\right.$; Fig. 3.6-B). The cell lysis model previously described for the Microcystis culturing experiment was also applied to the Planktothrix data. Its predictive accuracy for the Planktothrix data was weak and had a low slope value $\left(R^{2}=0.15\right)$, but it resulted in a statistically significant (linear regression, $p<0.001$; Fig. 3.7-A). As for the case of the Microcystis data, adjusting for excess lysed cells did not improve the model's strength (linear regression, $R^{2}=0.14, p<0.001 ;$ Fig. 3.7-B). 

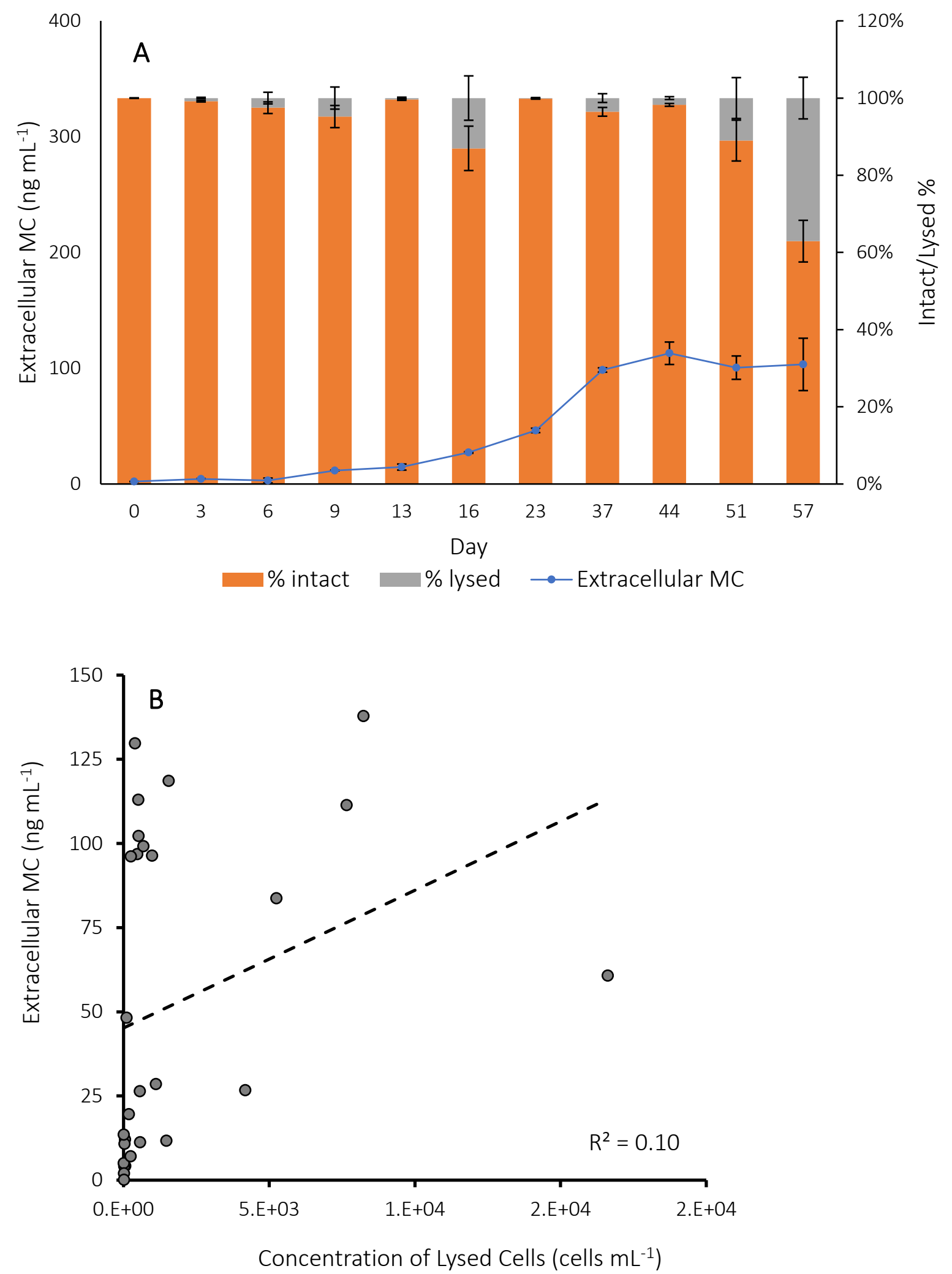

Figure 3.6 Time series of the concentration of extracellular microcystins (MC) and the proportion of lysed and intact cells in Planktothrix cultures (A), and concentration of extracellular MC as a function of the concentration of lysed Planktothrix cells (B). 

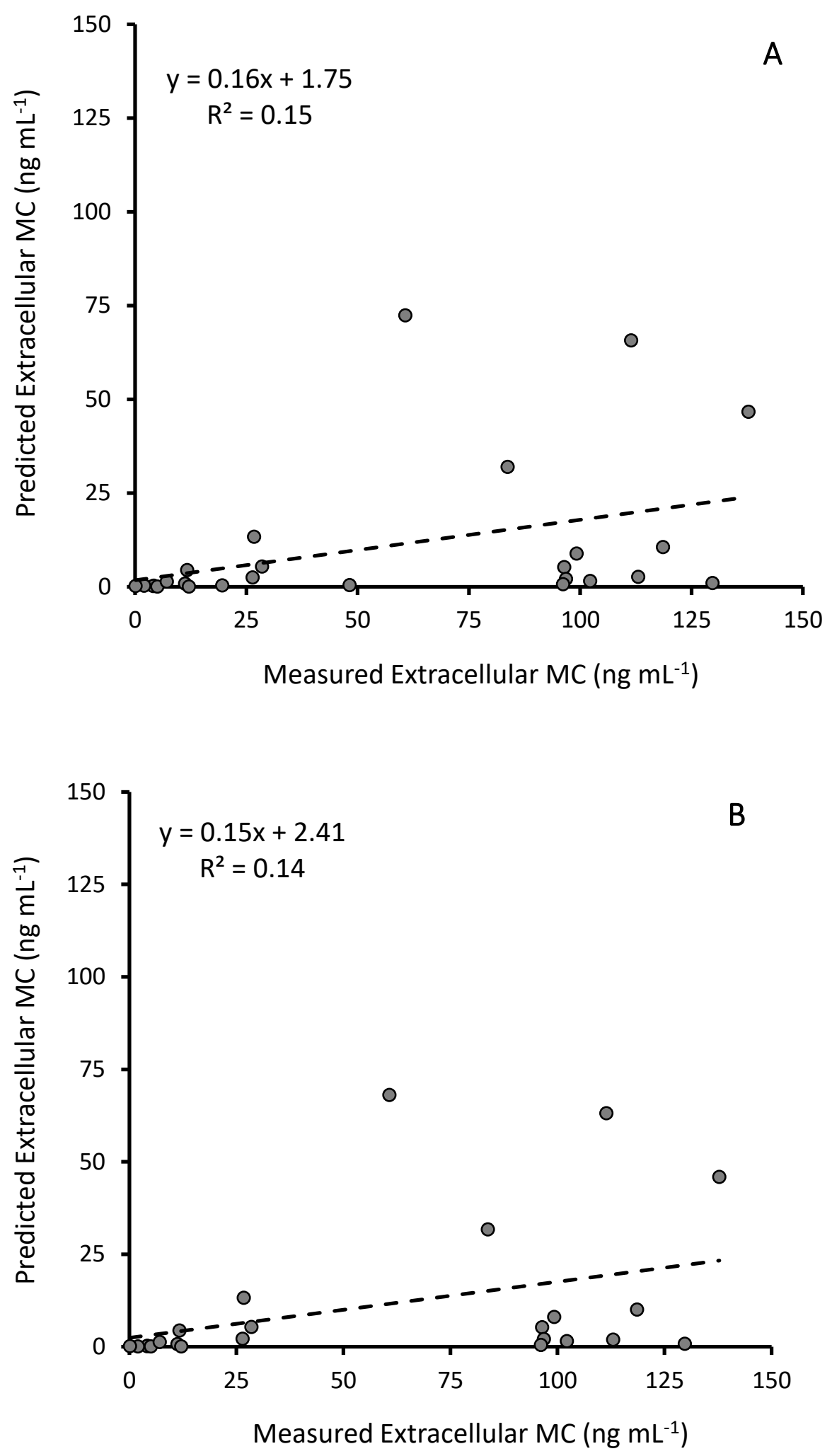

Figure 3.7 Predicted contribution of lysed cell MC to the extracellular environment, without adjustment for excess lysed cells (A), and with adjustment (B) for the Planktothrix cultures. 


\subsection{DISCUSSION}

Microcystis and Planktothrix are common genera of bloom-forming freshwater cyanobacteria that are frequently associated with the production of the cyanotoxin MC. Although the physiological role of $\mathrm{MC}$ is still debated, there is growing evidence of its role as a signalling molecule (Huang et al., 2019). However, in order to perform such functions, it is implied that the toxin must be released into the extracellular environment. Whilst cell lysis provides a simple mechanism for this, this export strategy is lacking in control, when compared to active export. The presence of an $A B C$ transporter protein in the mcy gene cluster (Pearson et al., 2004), as well as abnormal oscillations in extracellular toxins reported in previous studies (Wiedner et al., 2003; Cordeiro-Araujo et al., 2013), have provided some support for the theory proposing that $\mathrm{MC}$ are actively exported by cyanobacteria.

In a previous culturing experiment, the levels of extracellular aeruginosin, another secondary metabolite produced by Microcystis, remained constant while the intracellular aeruginosin quota fluctuated, suggesting that aeruginosins were likely not being actively exported out of the cell (Rogers, S., 2015). On the other hand, the same experiment showed a disproportional increase in extracellular MC, when compared to the extracellular aeruginosins observed on the same days, suggesting the potential for the active export of the former peptide. In further support of this hypothesis, the increase in extracellular MC also coincided with an increase in intracellular MC. While an attempt was made to monitor cell lysis during Rogers' experiment, the cell viability assay used for these measurements had a poor sensitivity and could not be used to assess cell viability. The dual-fluorescence assay developed in the present study could readily distinguish between intact and lysed cells, allowing the monitoring of cell lysis throughout the experiment. 
During the present experiment, increases in extracellular MC were coupled with increased cell Iysis for both species. There was a strong positive relationship between the concentration of lysed Microcystis cells and the concentration of extracellular MC, supporting the hypothesis that the concentration of extracellular MC observed in the cultures is explained by cell lysis. There was also a strong relationship between the measured extracellular MC concentrations and those predicted by the model for this strain. However, this model overestimated the concentration by a factor of 2.6 with respect to that measured by LC-MS/MS, possibly because protein-bound or degraded MCs were not detected by the analysis.

There was a weak but significant relationship between the observed quantities of cell lysis and the concentration of extracellular MC for Planktothrix. When the concentration of extracellular MC was predicted using the model with the Planktothrix data, the slope value obtained was low and there was a weak relationship between the measured extracellular MC concentration and the predicted concentration of lysed cells, and these results are considered unreliable.

Performing cell enumerations on the New Zealand strain of Planktothrix was problematic, in comparison to Microcystis. The cultures were viscous, with cells being visibly lost on pipette tips, grinder, and mortar during the sampling procedure and during the preparation of the 12well plates for cell counts. As noted in Chapter 2, the organic sheath secreted by Planktothrix may have prevented the SYTOX Green stain from evenly permeating the lysed cells. Various difficulties have been encountered in the past with the application of dyes belonging to the SYTOX family to other filamentous cyanobacterial strains (Johnson et al., 2016, Sato et al., 2004), attributed to the presence of pores connecting the cells within a filament. Together, these factors may explain the different responses observed between the two types of cyanobacteria. 
The levels of extracellular MC in Microcystis and Planktothrix were generally $3-10 \%$ of the cellular MC values. The extracellular MC concentration increased significantly during the experiment for both strains $(p<0.001)$. Whereas the MC concentrations continued to increase throughout the experiment with Microcystis, extracellular MC in Planktothrix peaked on day 44 and plateaued thereafter. The extracellular concentration of $\mathrm{MC}$ detected on days 37 for Microcystis was 6.5 times higher than that reported in a study of another Microcystis strain, at the same growth stage and grown under similar culturing conditions (Wei et al., 2016). In general, the external fraction of $\mathrm{MC}$ may contribute between as little as $5 \%$ and as much as $40 \%$ to the cellular fraction in axenic cultures (Orr and Jones, 1998; Rapala et al., 1997; Wiedner et al., 2003; Lyck et al., 2004; Jähnichen et al., 2011). It is also possible that the MC concentrations detected in the present study were underestimated, due to their degradation by heterotrophic bacteria or photobleaching (Kaebernick et al., 2000), or to the binding of MCs to proteins and peptides of other decaying cells (Wei et al., 2016). Further analysis of the kinetics of these reactions and processes should allow the model to be refined, leading to an improvement in its accuracy.

In the present study, the MC quotas increased despite the use of a constant light intensity throughout the experiment, following a pattern similar to that observed with extracellular MC concentrations. Lyck, S. (2004) found that MC quotas were the same at all stages of cell growth, whereas Long et al. (2001) observed a minimum of production at the lowest growth rate, and the highest production at maximum growth rate. However, high MC quota is not necessarily the consequence of a high rate of toxin synthesis, nor is a low MC quota necessarily the result of a low rate of $\mathrm{MC}$ synthesis. The lowest reported global MC quota for Microcystis strains is $0.006 \mathrm{pg}$ cell $^{-1}$ and the highest is $5.9 \mathrm{pg} \mathrm{cell}^{-1}$, however, the New Zealand MC quotas are 
generally higher than in other parts of the world (Puddick et al., 2019). In the present study, MC quotas doubled for Microcystis (0.03 $\mathrm{pg} \mathrm{cell}^{-1}$ to $0.07 \mathrm{pg}$ cell $\left.^{-1}\right)$, reaching levels comparable with the lowest median value observed in New Zealand (Puddick et al., 2019), whereas they increased by a factor of 8.5 in the case of Planktothrix (0.02 pg cell-1 to $\left.0.17 \mathrm{pg} \mathrm{cell}^{-1}\right)$.

An increase in the transcription of two $M C$ biosynthesis genes $(m c y B, m c y D)$, which was not coupled with an increase in intracellular levels of MC (Kaebernick et al., 2000), nor with a rapid increase in extracellular MC (Liu et al., 2017), was also observed in M. aeruginosa cultures under high illumination intensities. This suggests that the toxins may be constitutively produced under low and medium light intensities, but could be released to the extracellular environment only when a certain higher threshold of light intensity is reached, showing that the putative $\mathrm{MC}$ export may be enhanced by the higher rates of cell lysis induced by higher levels of irradiance. Monitoring the same variables investigated in the present study under high irradiances may lead to an improved understanding as to whether the increase in extracellular MCs observed under such conditions may be the result of increased cell lysis, and whether this occurs after a certain light intensity threshold is passed.

A possible SYTOX Green artefact comes from the lysed cells that may remain detectable by the dye after several days. This was addressed in Chapter 2, where the half-lives of decaying cells were determined for Microcystis and Planktothrix. However, even after adjusting the model for this, the relationship between measured and predicted extracellular MC did not significantly improve, and this was probably caused by the interval between sampling days, which allowed most of the damaged cells to degrade. However, this adjustment to the model could prove to be advantageous in experiments where the sampling is carried out more frequently. 
Overall, the findings of the present study indicate that cell lysis is potentially a major contributor of $\mathrm{MC}$ to the extracellular environment. However, investigations encompassing a wider range of $\mathrm{MC}$ producers, and further refinements of the methods should be undertaken to elucidate the mechanism behind the release of these toxins from cells. An improved understanding of this process would have important implications for the assessment of toxin concentrations in the water column, thus providing a useful tool for the prediction of $\mathrm{MC}$ bioaccumulation and its ecological impact on aquatic organisms (White et al., 2005). Progress in this area should contribute to the development of management strategies, which could be used to mitigate the toxicity of producing genera and allow the periods of greatest health risk during bloom events to be anticipated.

\subsection{Conclusions}

In order to test the hypothesis that the concentration of extracellular MC could be explained by cell lysis, a cell viability assay was coupled with analytical measurements of MC concentrations in two genera of bloom-forming cyanobacteria (Microcystis and Planktothrix). There was a strong and significant relationship between extracellular MC and cell lysis for Microcystis, whereas in the case of Planktothrix the relationship was weak, although surprisingly still significant. The model developed to predict the amount of extracellular toxins contributed by cell lysis showed that cell lysis over-estimated the concentration of extracellular MC. The same model again yielded weak but significant results for Planktothrix, suggesting that the conclusions for this strain should be treated cautiously. These results suggest that cell lysis is a substantial contributor to the development of extracellular MC in laboratory-grown Microcystis cultures. However, the data was not sufficiently accurate to conclude that the active export of $\mathrm{MC}$ did not also contribute to the observed quota of extracellular MC. A future 
study combining this staining technique with other physiological markers, while monitoring extracellular concentrations of $M C$ as well as $M C$ quota, may further elucidate the pathway followed by MC once they have been produced. 


\section{CHAPTER 4: Discussion and Future Directions}

While the biosynthesis pathway and toxic effects of the hepatotoxin microcystin (MC) are well understood, the physiological function of these metabolites remains a subject of debate (Huisman et al., 2018). The presence of an active export mechanism involved in regulating the release of toxins to the extracellular environment would partially support the role of these toxins as signalling molecules. Whilst increases in $\mathrm{MC}$ outside of cyanobacterial cells have long been attributed to cell lysis, studies suggest the potential for an active export mechanism involved in the release of the toxins: evidence of a putative $A B C$ transporter gene in the $m c y$ gene cluster (Pearson et al., 2004); increases in the translation of MC synthesis genes not matched by an increase in levels of intracellular MC (Kaebernick et al., 2000); localisation of MCs in the cell wall and sheath of intact cells (Shi et al., 1995); and abnormal oscillations in intra- and extracellular MCs (Cordeiro-Araujo et al., 2013). However, these studies have not excluded cell lysis as the primary contributor of MCs to the extracellular environment. In the first part of the current study, a dual-fluorescence assay was optimised for use on two common MC producers, Microcystis and Planktothrix. This staining procedure was then successfully employed in a culturing experiment, in an effort to assess whether the concentration of extracellular MC would be explained by the amount of cell lysis occurring in the cultures. As levels of cell lysis steadily increased in batch culture experiments, so did concentrations of extracellular MCs and the relationship between the two was strong and significant. This supports the hypothesis that cell lysis is a major contributor of MCs to the extracellular environment for Microcystis. 
The dual-fluorescence assay described in Chapter 2 readily discriminated between lysed cells and intact cells for both Microcystis and Planktothrix. This was essential to the development of a model that predicts the contribution of extracellular MC from lysed cells. The assay worked best on Microcystis, but background fluorescence interference was detected when applied to Planktothrix. This background signal was due to the presence of a mucilaginous sheath containing heterotrophic bacteria. However, this problem was easily overcome by adjusting the threshold for image analysis so that heterotrophic bacteria could be excluded.

The optimal fluorescence parameters for these two cyanobacteria apply to laboratory-grown cultures, and SYTOX Green staining concentration and incubation times may need to be considerably different for field samples, as previously observed for Microcoleus autumnalis (Tashyreva et al., 2013). Moreover, while Microcystis is often found as single cells in laboratory conditions, it commonly forms colonies in the natural environment and secretes higher levels of mucilage (Yang et al., 2009), potentially leading to further complications with field samples. Problems were encountered when measuring cell concentrations for the Planktothrix strain because filaments were visibly lost in the preparation of samples for cell enumeration. Not surprisingly, when the lysis model was applied to the data collected for this strain, it did not yield a strong relationship between the observed levels of extracellular MCs and the levels contributed by lysed cells.

Determining whether naturally lysed cells stain similarly to ethanol-treated cells when incubated with the SYTOX Green dye would also further validate this assay and consequently the prediction model for the concentration of extracellular toxins. Since protein-bound or degraded MCs may not be detected by the LC-MS/MS analysis, refining MC sampling 
procedures and determining whether any $M C$ degradation occurs during sampling timeframes under the culturing conditions used may also improve the model.

The results described for Microcystis in Chapter 3 suggest that lysed cells contribute all of the $M C$ detected in the extracellular environment, and do not support the $M C$ active export hypothesis. Nonetheless, the role of these toxins as signaling molecules is still plausible, since for MCs to play such a role, they must first be released to the extracellular environment. In this scheme, it is possible that the release of MCs is associated with programmed cell death (PCD; Ding et al., 2012). Certainly, some MCs are released to the surrounding media during growth and under different environmental conditions (Wood et al., 2011). The occurrence of apoptosis-like death in both toxic and non-toxic Microcystis strains has also been demonstrated under various environmental conditions, with a significant release of MCs into the environment (Hu et al., 2019). Moreover, MC production and PCD are associated: they are assumed to confer a relative physiological advantage to producers; the occurrence of PCD naturally accompanies the release of $\mathrm{MC}$; both processes have an ancient evolutionary root; there exists a strong association between PCD and upregulation of MC production; and metacascapases (i.e., genes linked with apoptosis induction) are found in both Microcystis and Nodularia (Hu et al., 2019).

In Planktothrix, MC release may be caused by necrosis, a more passive form of PCD (Ding et al., 2012). Necridia, or 'sacrificial' cells, are generally used for reproductive purposes by members of the order Oscillatoriales. In the dual fluorescence assay of the current study, SYTOX Green-stained Planktothrix cells were often located at either end of the filament, likely where the parent filament would have broken. Since cyanobacteria do not possess mitochondria, and PCD death is a light-dependent process, the photosynthetic apparatus of 
cyanobacteria may have full control over cell death regulation (Ding et al., 2012). Programmed cell death and the subsequent release of toxins may be a mechanism adopted by cyanobacteria to cope with changing conditions, such as drastic fluctuations in light intensity and temperature (Schatz et al. 2007), and the advantages may include enhanced colony formation (Sedmak et al., 2005) and protection against photo-oxidation stresses such as high light or carbon deficiency (Latifi et al., 2009; Foyer and Shigeoka, 2011; Janichen et al., 2008). Under such conditions, $\mathrm{MC}$ biosynthesis becomes advantageous despite its high energy demand and a form of controlled death could confer an advantage to the remaining cells (Ding et al., 2012). In light of this, results from the current study do not necessarily exclude the possibility of a controlled release of MCs to the extracellular environment.

Bacteria must often coordinate physiological processes based on limited information about the external environment, and in many cases this is aided by the secretion and detection of small diffusible molecules, in a process called 'quorum sensing' (Cornforth et al., 2014). Quorum sensing systems are well known in gram-negative bacteria, as they can aid the coordination of important biological functions such as motility, aggregation, plasmid conjugal transfer, symbiosis and biofilm maintenance (Romero et al., 2011). This process is usually mediated by the accumulation of signaling molecules under higher cell densities, and it often controls the expression of more complex secondary metabolites. For instance, MC appears to be a proximal cue for the induction of genes responsible for the production of other secondary metabolites (Briand et al., 2016). Moreover, the presence of toxins outside the cells further stimulate its biosynthesis via enhanced expression of the mcy gene cluster (Schatz et al., 2007). Interestingly, recent studies with the gram-negative bacterium Pseudomonas aeruginosa provided evidence that, by using only multiple and interconnected signals with distinct half- 
lives, the cells could infer both their social (density) and physical (mass-transfer) environments and simultaneously match gene expression to both (Cornforth et al., 2014; Moghaddam et al., 2014).

Cyanobacteria often need to coordinate movements within the colony and within the water column, for instance to access photosynthetically active radiation and nutrients, or to avoid high light intensities. Molecules involved in quorum sensing systems often guide the performance of such tasks, and the presence of such systems has been demonstrated to some extent for Anabaena (Romero et al., 2011), Gloeothece (Shariff et al., 2008) and Trichodesmium (Van Mooy et al., 2012). The association of MC production with colony formation (Sedmak et al., 2005), and protection against photo-oxidation stresses such as high light intensity or carbon deficiency (Latifi et al., 2009) suggests MC may play a part in quorum sensing systems and the extracellular movement of the toxins may trigger responses in the remaining cells. For instance, it was reported that extracellular MC-LR observed under high irradiances in Microcystis cultures is not actively transported into cells, but it is rather perceived and transduced by a receptor-mediated signaling cascade, providing some evidence for the involvement of MC in some intercellular communication process (Makower et al., 2015). One main argument against the allelopathic effects of $M C$ is that this process will be effective only if toxin producing strains are sufficiently abundant and produce enough toxin to suppress toxin-sensitive strains (Kardinaal et al., 2007). Natural MC concentrations, as commonly found in Microcystis blooms, are generally too low to have allelopathic effects on other photoautotrophic organisms (Babica et al., 2006). Despite high Microcystis densities observed in the cultures, the extracellular fraction of MC detected in this experiment may still have been 
too low to have any potential allelopathic effects, especially considering that it was between 3 and $10 \%$ of the total MC produced.

Although there is some evidence that $M C$ provides an advantage over competing phytoplankton such as chlorophytes and diatoms (Pflugmacher, 2002; Wang et al., 2015), and offers defense against grazing (Rohrlack et al., 1999; Jang et al., 2008), other studies have found no correlation between toxin production and presence of Microcystis ecological competitors (Banerji al., 2019) or between direct exposure to grazers and MC gene expression (Harke et al., 2017). Since phylogenetic analyses revealed an early origin of MCs that predates the origin of cyanobacterial predators, it is possible that the release of MCs to the extracellular environment may have co-opted different purposes over the course of cyanobacterial evolution, such as anti-predator defense and allelopathy. It is also conceivable that $\mathrm{MC}$ toxicity to other organisms is purely fortuitous, and that the loss of MC-biosynthesis genes by nontoxic strains is explained by the presence of similar, structurally related but non-toxic compounds that may serve a similar physiological function, possibly at lower energetic costs.

Since in this study cell lysis explained the extracellular concentration of $\mathrm{MC}$, and considering the high amount of carbon and nitrogen devoted to toxin biosynthesis, $M C$ may also play a primarily intracellular role, conferring a direct adaptive advantage to the producer species (Ceballos-Laita et al., 2017). The relationship between MC production and cell division rates suggests an important role of MC in cellular metabolism of toxigenic strains (Orr and Jones, 1997). The role of MC in photosynthesis is partly supported by the finding that two-thirds of the intracellular MCs are located around the thylakoids of immuno-gold labelled Microcystis cells (Shi et al., 1995). However, MCs may also play a role in: binding to proteins under high light and oxidative stress conditions (Zilliges et al., 2011); maintaining the photosynthetic 
machinery (Wang et al., 2018); sequestration or storage of $P$ and trace metals such as iron (Sevilla et al., 2008; Shi et al., 2013; Harke and Gobler, 2013); removal of oxidative by-products (Latifi et al., 2009; Foyer and Shigeoka, 2011); and binding of the global nitrogen regulator NtcA protein in the bidirectional mcy promoter region, which is important in the carbon-nitrogen metabolism (Makower et al., 2014).

\subsection{Future Directions}

Broadening the applicability of the dual-fluorescence method to different MC-producing genera (e.g., Dolichospermum, Anabaena, Nodularia) could prove a useful tool to further determine the fate of MCs after they are produced, thus further elucidating the potential role of these toxins. For instance, the mcy gene cluster encoding for MCs between producing genera, and the nda gene cluster encoding for nodularins (hepatotoxins structurally similar to $\mathrm{MC}$ ), share similar multienzyme components, but the position of the tailoring genes and of the putative ATP binding cassette transporter gene differ (Dittmann et al., 2005). The finding that nodularins produced by Nodularia spumigena form pores in lipid bilayers (Spassova et al., 1995) suggests that these toxins may also act as transmembrane transporters. A comparison between extracellular nodularins and MCs could therefore provide valuable information about the role of these toxins. However, while SYTOX Green stain has been successfully applied to Planktothrix, Dolichospermum and Microcoleus (Sato et al., 2004; Tashyreva et al., 2013), applying such staining techniques on other filamentous strains is often problematic. For instance, SYTOX Blue did not reliably stain Anabaena cells, potentially due to the leakage of the dye through intercellular pores (Johnson et al., 2015). Moreover, mucilage production and heterotrophic bacterial contamination may substantially complicate the application of SYTOX Green to Nodularia. Strategies to overcome these problems may encompass chemically 
removing the mucilage sheath or growing the cultures with antibiotics, respectively. Considering that many MC-producers are filamentous, optimising the dye for these strains may prove an important development.

The use of 'dead cell' stains (including SYTOX Green) does not allow for the identification of intermediate states of cell injury that can be followed by cell recovery rather than death (Berney et al. 2007), which may partly explain why the model developed in this study overestimated the concentrations of extracellular MC contributed by lysed cells. The SYTOX Green stain has been successfully applied, in combination with other physiological markers, to detect different stages of cell injury on Microcoleus autumnalis (Tashyreva et al., 2013). The authors could classify cyanobacterial populations into four categories: (i) active and intact; (ii) injured but active; (iii) metabolically inactive but intact; (iv) inactive and injured, or dead. By combining the proposed set of physiological markers to monitor respiratory rate, membrane integrity, the presence and integrity of a nucleoid, and photosynthetic pigments, it should be possible to understand the physiological state of MC-producing cells, while at the same time following the intra- and extra-cellular movements of MC.

The ability to produce $M C$ is not intrinsic to all taxa or strains. However, it is assumed that $M C$ production provides an ecological advantage to the producer strains, considering its high energetic cost (Jahnichen et al. 2008). The increase in MC biosynthesis and higher concentrations of extracellular MC detected under high irradiances (Utkilen and Gjølme, 1992), suggest that light intensity alterations could provide an excellent tool for further investigations of the fate of MCs after they are produced. Because numerous cellular processes are also controlled by light intensity, factors such as cell division should also be closely monitored as this also has an impact on toxin transcription/production. Moreover, using a set of 
physiological markers to monitor respiratory rate, membrane integrity, the presence and integrity of a nucleoid, and photosynthetic pigments may provide a better insight into other processes possibly involved in the release of the toxins and whether an active export mechanism may exist.

Climate change is likely to exacerbate the dominance of harmful cyanobacteria in aquatic ecosystems globally, increasing the need for a better understanding of toxin production and dynamics in the water column (Carey et al. 2012; Paerl and Paul 2012). Determining whether MCs or other cyanobacterial secondary metabolites are released in a controlled fashion by producer cells may shed light over the highly debated physiological role of the toxins. This could in turn assist monitoring and management procedures when toxic blooms form, and it may help predicting when levels of highest toxicity are reached. 


\section{REFERENCES}

- Agarwal, R., Whitelegge, J. P., Saini, S., \& Shrivastav, A. P. (2018). The S-layer biogenesis system of Synechocystis 6803: Role of Sll1180 and Sll1181 (E. coli HlyB and HlyD analogs) as type-I secretion components for SII1951 export. Biochimica et Biophysica Acta-Biomembranes, 1860 (7), 1436-1446.

- Babica, P., Bláha, L., \& Maršálek, B. (2006). Exploring the natural role of microcystinsA review of effects on photoautotrophic organisms. Journal of Phycology, 42 (1), 9-20.

- Banerji, A., Bagley, M., Shoemaker, J., Tettenhorst, D., Nietch, C., Allen, H., \& Santo Domingo, J. (2019). Evaluating putative ecological drivers of microcystin spatiotemporal dynamics using metabarcoding and environmental data. Harmful Algae, 86, 84-95.

- Berney, M., Hammes, F., Bosshard, F., Weilenmann, H.-U., \& Egli, T. (2007). Assessment and interpretation of bacterial viability by using the LIVE/DEAD BacLight Kit in combination with flow cytometry. Applied Environmental Microbiology, 73 (10), 32833290.

- Biegala, I. C., Kennaway, G., Alverca, E., Lennon, J. F., Vaulot, D., \& Simon, N. (2002). Identification of bacteria associated with Dinoflagellates (Dinophyceae) Alexandrium spp. using tyramide signal amplification-fluorescent in situ hybridization and confocal microscopy. Journal of Phycology, 38 (2), 404-411.

- Bischofberger, M., Gonzalez, M. R., \& van der Goot, F. G. (2009). Membrane injury by pore-forming proteins. Current Opinion in Cell Biology, 21 (4), 589-595.

- Bittencourt-Oliveira, M.C., Kujbida, P., Cardozo, K. H. M., Carvalho, V. M., do Nascimento Moura, A., Colepicolo, P., \& Pinto, E. (2005). A novel rhythm of microcystin biosynthesis is described in the cyanobacterium Microcystis panniformis. Biochemical and Biophysical Research Communications, 326 (3), 687-694.

- Bolch C.J.S. and Blackburn S.I., 1996. Isolation and purification of Australian isolates of the toxic cyanobacterium Microcystis aeruginosa. Applied Phycology, 8, 5-13 
- Bonnington, K., \& Kuehn, M. (2014). Protein selection and export via outer membrane vesicles. Biochimica et Biophysica Acta-Molecular Cell Research, 1843 (8), 1612-1619.

- Borges, A., \& Simões, M. (2019). Quorum sensing inhibition by marine bacteria. Marine Drugs, 17(7), 427.

- Bouma-Gregson, K., Power, M. E., \& Bormans, M. (2017). Rise and fall of toxic benthic freshwater cyanobacteria (Anabaena spp.) in the Eel river: Buoyancy and dispersal. Harmful Algae, 66, 79-87.

- Braun, P. D., Schulz-Vogt, H. N., Vogts, A., \& Nausch, M. (2018). Differences in the accumulation of phosphorus between vegetative cells and heterocysts in the cyanobacterium Nodularia spumigena. Scientific Reports, 8 (1), 5651.

- Briand, E., Bormans, M., Gugger, M., Dorrestein, P. C., \& Gerwick, W. H. (2016). Changes in secondary metabolic profiles of Microcystis aeruginosa strains in response to intraspecific interactions. Environmental Microbiology, 18 (2), 384-400.

- Briand, E., Bormans, M., Quiblier, C., Salençon, M.-J., \& Humbert, J.-F. (2012). Evidence of the cost of the production of microcystins by Microcystis aeruginosa under differing light and nitrate environmental conditions. PLoS One, 7 (1): e29981.

- Buratti, F. M., Manganelli, M., Vichi, S., Stefanelli, M., Scardala, S., Testai, E., \& Funari, E. (2017). Cyanotoxins: Producing organisms, occurrence, toxicity, mechanism of action and human health toxicological risk evaluation. Archives of Toxicology, 91 (3), 10491130.

- Carey, C. C., Ibelings, B. W., Hoffmann, E. P., Hamilton, D. P., \& Brookes, J. D. (2012). Eco-physiological adaptations that favour freshwater cyanobacteria in a changing climate. Water Research, 46 (5), 1394-1407.

- Catherine, A., Quiblier, C., Yéprémian, C., Got, P., Groleau, A., Vinçon-Leite, B., \& Troussellier, M. (2008). Collapse of a Planktothrix agardhii perennial bloom and microcystin dynamics in response to reduced phosphate concentrations in a temperate lake. FEMS Microbiology Ecology, 65 (1), 61-73.

- Chaffin, J. D., Davis, T. W., Smith, D. J., Baer, M. M., \& Dick, G. J. (2018). Interactions between nitrogen form, loading rate, and light intensity on Microcystis and Planktothrix growth and microcystin production. Harmful Algae, 73, 84-97.

- Christiansen, G., Fastner, J., Erhard, M., Börner, T., \& Dittmann, E. (2003). Microcystin 
biosynthesis in Planktothrix: Genes, evolution, and manipulation. Journal of Bacteriology, 185 (2), 564-572.

- Codd, G., Bell, S., Kaya, K., Ward, C., Beattie, K., \& Metcalf, J. (1999). Cyanobacterial toxins, exposure routes and human health. European Journal of Phycology, 34, 405415.

- Cordeiro-Araújo, M. K., \& Bittencourt-Oliveira, M. C. (2013). Active release of microcystins controlled by an endogenous rhythm in the cyanobacterium Microcystis aeruginosa. Phycological Research, 61(1), 1-6.

- Cornforth, D. M., Popat, R., McNally, L., Gurney, J., Scott-Phillips, T. C., Ivens, A., \& Brown, S. P. (2014). Combinatorial quorum sensing allows bacteria to resolve their social and physical environment. Proceedings of the National Academy of Sciences, 111 (11), 4280-4284.

- Dai, R., Wang, P., Jia, P., Zhang, Y., Chu, X., \& Wang, Y. (2016). A review on factors affecting microcystins production by algae in aquatic environments. World Journal of Microbiology and Biotechnology, 32 (3), 51.

- Dantas, Ê. W., Moura, A. N., \& Bittencourt-Oliveira, M. C. (2011). Cyanobacterial blooms in stratified and destratified eutrophic reservoirs in semi-arid region of Brazil. Anais da Academia Brasileira de Ciências, 83 (4), 1327-1338.

- Darzynkiewicz, Z., Li, X., \& Gong, J. (1994). Assays of cell viability: Discrimination of cells dying by apoptosis. Methods in Cell Biology, 41, 15-38.

- Ding, Y., Gan, N., Li, J., Sedmak, B., \& Song, L. (2012). Hydrogen peroxide induces apoptotic-like cell death in Microcystis aeruginosa (Chroococcales, Cyanobacteria) in a dose-dependent manner. Phycologia, 51 (5), 567-575.

- Dittmann, E., \& Börner, T. (2005). Genetic contributions to the risk assessment of microcystin in the environment. Toxicology and Applied Pharmacology, 203 (3), 192200.

- Dittmann, E., Erhard, M., Kaebernick, M., Scheler, C., Neilan, B. A., von Döhren, H., \& Börner, T. (2001). Altered expression of two light-dependent genes in a microcystinlacking mutant of Microcystis aeruginosa PCC 7806. Microbiology, 147 (11), 3113-3119.

- Dodds, W. K., Bouska, W. W., Eitzmann, J. L., Pilger, T. J., Pitts, K. L., Riley, A. J., \& Thornbrugh, D. J. (2008). Eutrophication of US freshwaters: Analysis of potential 
economic damages. In: Environmental Science and Technology. 2009, 43, 1, 12-19.

- Downing, T., Phelan, R., \& Downing, S. (2015). A potential physiological role for cyanotoxins in cyanobacteria of arid environments. Journal of Arid Environments, 112, 147-151.

- Dunn, R. M., \& Manoylov, K. M. (2016). The effects of initial cell density on the growth and proliferation of the potentially toxic cyanobacterium Microcystis aeruginosa. Journal of Environmental Protection, 7 (9), 1210-1220.

- Elliott, J. A. (2012). Is the future blue-green? A review of the current model predictions of how climate change could affect pelagic freshwater cyanobacteria. Water Research, $46(5), 1364-1371$.

- Emerson, J. B., Adams, R. I., Román, C. M. B., Brooks, B., Coil, D. A., Dahlhausen, K., \& Justice, N. B. (2017). Schrödinger's microbes: Tools for distinguishing the living from the dead in microbial ecosystems. Microbiome, 5 (1), 86.

- Felipe de Mendiburu (2020). Agricolae: Statistical procedures for agricultural research . R package version 1.3-2. https://CRAN.R-project.org/package=agricolae

- Fewer, D. P., Rouhiainen, L., Jokela, J., Wahlsten, M., Laakso, K., Wang, H., \& Sivonen, K. (2007). Recurrent adenylation domain replacement in the microcystin synthetase gene cluster. BMC Evolutionary Biology, 7 (1), 183.

- Foyer, C. H., \& Shigeoka, S. (2011). Understanding oxidative stress and antioxidant functions to enhance photosynthesis. Plant Physiology, 155 (1), 93-100.

- Francis, G. (1878). Poisonous Australian lake. Nature, 18 (444), 11-12.

- Gągała, I., \& Mankiewicz-Boczek, J. (2012). The natural degradation of microcystins (cyanobacterial hepatotoxins) in fresh water: The future of modern treatment systems and water quality improvement. Polish Journal of Environmental Studies, 21 (5), 11251139.

- Gallardo-Rodríguez, J., López-Rosales, L., Sánchez-Mirón, A., García-Camacho, F., \& Molina-Grima, E. (2016). Rapid method for the assessment of cell lysis in microalgae cultures. Journal of Applied phycology, 28 (1), 105-112.

- Granéli, E., \& Hansen, P. J. (2006). Allelopathy in harmful algae: A mechanism to compete for resources? Ecology of Harmful Algae, 189, 189-201. 
- Gregoire Pau, Florian Fuchs, Oleg Sklyar, Michael Boutros, \& Wolfgang Huber (2010). E Blmage - An R package for image processing with applications to cellular phenotypes. Bioinformatics, 26 (7), 979-981,

- Guo, Y. C., Lee, A. K., Yates, R. S., Liang, S., \& Rochelle, P. A. (2017). Analysis of microcystins in drinking water by ELISA and LC/MS/MS. Journal-American Water Works Association, 109 (3), 13-25.

- Hadley Wickham (2019). Stringr: Simple, consistent wrappers for common string oper ations. R package version 1.4.0. https://CRAN.R-project.org/package=stringr.

- Harke, M. J., \& Gobler, C. J. (2013). Global transcriptional responses of the toxic cyanobacterium, Microcystis aeruginosa, to nitrogen stress, phosphorus stress, and growth on organic matter. PLoS One, 8 (7): e69834.

- Harke, M. J., Jankowiak, J. G., Morrell, B. K., \& Gobler, C. J. (2017). Transcriptomic responses in the bloom-forming cyanobacterium Microcystis induced during exposure to zooplankton. Applied Environmental Microbiology., 83 (5), e02832-02816.

- Harke, M. J., Steffen, M. M., Gobler, C. J., Otten, T. G., Wilhelm, S. W., Wood, S. A., \& Paerl, H. W. (2016). A review of the global ecology, genomics, and biogeography of the toxic cyanobacterium, Microcystis spp. Harmful Algae, 54, 4-20.

- Hu, C., \& Rzymski, P. (2019). Programmed cell death-like and accompanying release of microcystin in freshwater bloom-forming cyanobacterium Microcystis: from identification to ecological relevance. Toxins, 11 (12), 706.

- Hu, Z. Q., Liu, Y. D,, \& Li, D. H. (2004). Physiological and biochemical analyses of microcystin-RR toxicity to the cyanobacterium Synechococcus elongatus. Environmental Toxicology: An International Journal, 19 (6), 571-577.

- Huang, I.-S., \& Zimba, P. V. (2019). Cyanobacterial bioactive metabolites-A review of their chemistry and biology. Harmful Algae, 83, 42-94.

- Huisman, J., Codd, G. A., Paerl, H. W., Ibelings, B. W., Verspagen, J. M., \& Visser, P. M. (2018). Cyanobacterial blooms. Nature Reviews Microbiology, 16 (8), 471.

- Jacinavicius, F., Pacheco, A., Chow, F., Verissimo, G., Kalume, D., Rigonato, J., Schmidt, E.C., \& Sant'Anna, C. (2019). Different ecophysiological and structural strategies of toxic and non-toxic Microcystis aeruginosa (cyanobacteria) strains assessed under culture conditions. Algal Research, 41. 
- Jähnichen, S., Ihle, T., \& Petzoldt, T. (2008). Variability of microcystin cell quota: A small model explains dynamics and equilibria. Limnologica, 38 (3-4), 339-349.

- Jähnichen, S., Long, B. M., \& Petzoldt, T. (2011). Microcystin production by Microcystis aeruginosa: Direct regulation by multiple environmental factors. Harmful Algae, 12, 95104.

- Jang, M.-H., Ha, K., \& Takamura, N. (2008). Microcystin production by Microcystis aeruginosa exposed to different stages of herbivorous zooplankton. Toxicon, 51 (5), 882-889.

- Janse, I., Kardinaal, W. E. A., Agterveld, M. K., Meima, M., Visser, P. M., \& Zwart, G. (2005). Contrasting microcystin production and cyanobacterial population dynamics in two Planktothrix-dominated freshwater lakes. Environmental Microbiology, 7 (10), 1514-1524.

- Janssen, E. M. L. (2019). Cyanobacterial peptides beyond microcystins-A review on cooccurrence, toxicity, and challenges for risk assessment. Water Research, 151, 488-499.

- Jochimsen, E. M., Carmichael, W. W., An, J., Cardo, D. M., Cookson, S. T., Holmes, C. E. M., \& Jarvis, W. R. (1998). Liver failure and death after exposure to microcystins at a hemodialysis center in Brazil. The New England Journal of Medicine 338 (13), 873-878.

- Johnson, T. J., Hildreth, M. B., Gu, L., Baldwin, E. L., Zhou, R., \& Gibbons, W. R. (2016). Evaluating viable cell indicators for filamentous cyanobacteria and their application. Journal of Microbiology, Biotechnology and Food Sciences, 2019, 886-893.

- Kaebernick, M., \& Neilan, B. A. (2001). Ecological and molecular investigations of cyanotoxin production. 35 (1), 1-9.

- Kaebernick, M., Dittmann, E., Börner, T., \& Neilan, B. A. (2002). Multiple alternate transcripts direct the biosynthesis of microcystin, a cyanobacterial nonribosomal peptide. Applied Environmental. Microbiology., 68(2), 449-455.

- Kaebernick, M., Neilan, B. A., Börner, T., \& Dittmann, E. (2000). Light and the transcriptional response of the microcystin biosynthesis gene cluster. Applied Environmental Microbiology., 66 (8), 3387-3392.

- Kardinaal, W. E. A., Tonk, L., Janse, I., Hol, S., Slot, P., Huisman, J., \& Visser, P. M. (2007). Competition for light between toxic and nontoxic strains of the harmful cyanobacterium Microcystis. Applied Environmental Microbiology., 73 (9), 2939-2946. 
- Kehr, J. C., Zilliges, Y., Springer, A., Disney, M. D., Ratner, D. D., Bouchier, C., \& Dittmann, E. (2006). A mannan binding lectin is involved in cell-cell attachment in a toxic strain of Microcystis aeruginosa. Molecular Microbiology, 59 (3), 893-906.

- Komárek, J. (2016). A polyphasic approach for the taxonomy of cyanobacteria: Principles and applications. European Journal of Phycology, 51 (3), 346-353.

- Kubickova, B., Laboha, P., Hildebrandt, J.-P., Hilscherová, K., \& Babica, P. (2019). Effects of cylindrospermopsin on cultured immortalized human airway epithelial cells. Chemosphere, 220, 620-628.

- Kurmayer, R., \& Kutzenberger, T. (2003). Application of real-time PCR for quantification of microcystin genotypes in a population of the toxic cyanobacterium Microcystis sp. Applied Environmental. Microbiology., 69 (11), 6723-6730.

- Latifi, A., Ruiz, M., \& Zhang, C.-C. (2009). Oxidative stress in cyanobacteria. FEMS Microbiology Reviews, 33 (2), 258-278.

- Lebaron, P., Catala, P., \& Parthuisot, N. (1998). Effectiveness of SYTOX Green stain for bacterial viability assessment. Applied Environmental Microbiology., 64 (7), 2697-2700.

- Lewis Jr, W. M., \& Wurtsbaugh, W. A. (2008). Control of lacustrine phytoplankton by nutrients: Erosion of the phosphorus paradigm. International Review of Hydrobiology, 93 (4-5), 446-465.

- Li, Y., \& Li, D. (2012). Competition between toxic Microcystis aeruginosa and nontoxic Microcystis wesenbergii with Anabaena PCC7120. Journal of Applied Phycology, 24 (1), 69-78.

- Liu, B., Qu, F., Chen, W., Liang, H., Wang, T., Cheng, X., \& Van der Bruggen, B. (2017). Microcystis aeruginosa-laden water treatment using enhanced coagulation by persulfate/Fe (II), ozone and permanganate: Comparison of the simultaneous and successive oxidant dosing strategy. Water Research, 125, 72-80.

- Long, B. M. (2001). The influence of growth conditions on the intracellular microcystin quota of Microcystis aeruginosa. (doctoral dissertation), La Trobe University, Melbourne, Australia.

- Lürling, M. (2003). Effects of microcystin-free and microcystin-containing strains of the cyanobacterium Microcystis aeruginosa on growth of the grazer Daphnia magna. Environmental Toxicology, 18(3), 202-210. 
- Lyck, S. (2004). Simultaneous changes in cell quotas of microcystin, chlorophyll a, protein and carbohydrate during different growth phases of a batch culture experiment with Microcystis aeruginosa. Journal of Plankton Research, 26 (7), 727-736.

- Machado, M. D., \& Soares, E. V. (2012). Development of a short-term assay based on the evaluation of the plasma membrane integrity of the alga Pseudokirchneriella subcapitata. Applied Microbiology and Biotechnology, 95 (4), 1035-1042.

- Machado, M. D., \& Soares, E. V. (2015). Use of a fluorescence-based approach to assess short-term responses of the alga Pseudokirchneriella subcapitata to metal stress. Journal of Applied Phycology, 27 (2), 805-813.

- Makower, A. K., Schuurmans, J. M., Groth, D., Zilliges, Y., Matthijs, H. C., \& Dittmann, E. (2015). Transcriptomics-aided dissection of the intracellular and extracellular roles of microcystin in Microcystis aeruginosa PCC 7806. Applied Environmental Microbiology., $81(2), 544-554$.

- Martin-Luna, B., Sevilla, E., Hernandez, J. A., Bes, M. T., Fillat, M. F., \& Peleato, M. L. (2006). Fur from Microcystis aeruginosa binds in vitro promoter regions of the microcystin biosynthesis gene cluster. Phytochemistry, 67 (9), 876-881.

- Metcalf, J. S., Reilly, M., Young, F. M., \& Codd, G. A. (2009). Localization of microcystin synthetase genes in colonies of the cyanobacterium Microcystis using fluorescence in situ hybridization. Journal of Phycology, 45 (6), 1400-1404.

- Moghaddam, M. M., Khodi, S., \& Mirhosseini, A. (2014). Quorum sensing in bacteria and a glance on Pseudomonas aeruginosa. Clinical Microbiology: Open Access, 3 (4).

- Moore, R. E., Chen, J. L., Moore, B. S., Patterson, G. M., \& Carmichael, W. W. (1991). Biosynthesis of microcystin-LR: Origin of the carbons in the Adda and Masp units. Journal of the American Chemical Society, 113 (13), 5083-5084.

- Mullineaux, C. W., Mariscal, V., Nenninger, A., Khanum, H., Herrero, A., Flores, E., \& Adams, D. G. (2008). Mechanism of intercellular molecular exchange in heterocystforming cyanobacteria. The EMBO Journal, 27 (9), 1299-1308.

- Neilan, B. A., Pearson, L. A., Muenchhoff, J., Moffitt, M. C., \& Dittmann, E. (2013). Environmental conditions that influence toxin biosynthesis in cyanobacteria. Environmental Microbiology, 15 (5), 1239-1253.

- Nishizawa, T., Ueda, A., Asayama, M., Fujii, K., Harada, K.-i., Ochi, K., \& Shirai, M. (2000). 
Polyketide synthase gene coupled to the peptide synthetase module involved in the biosynthesis of the cyclic heptapeptide microcystin. The Journal of Biochemistry, 127 (5), 779-789.

- O'neil, J., Davis, T., Burford, M., \& Gobler, C. (2012). The rise of harmful cyanobacteria blooms: The potential roles of eutrophication and climate change. Harmful Algae, 14, 313-334.

- Oh, H. M., Lee, S. J., Jang, M. H., \& Yoon, B. D. (2000). Microcystin production by Microcystis aeruginosa in a phosphorus-limited chemostat. Applied Environmental Microbiology 66 (1), 176-179.

- Omidi, A., Esterhuizen-Londt, M., \& Pflugmacher, S. (2018). Still challenging: the ecological function of the cyanobacterial toxin microcystin-What we know so far. Toxin Reviews, 37 (2), 87-105.

- Orr, P. T., \& Jones, G. J. (1998). Relationship between microcystin production and cell division rates in nitrogen-limited Microcystis aeruginosa cultures. Limnology and Oceanography, 43 (7), 1604-1614.

- Paerl, H. W., \& Huisman, J. (2008). Blooms like it hot. Science, 320 (5872), 57-58.

- Paerl, H. W., \& Paul, V. J. (2012). Climate change: links to global expansion of harmful cyanobacteria. Water Research, 46 (5), 1349-1363.

- Paerl, H. W., Hall, N. S., \& Calandrino, E. S. (2011). Controlling harmful cyanobacterial blooms in a world experiencing anthropogenic and climatic-induced change. Science of the Total Environment, 409 (10), 1739-1745.

- Pancrace, C., Barny, M.-A., Ueoka, R., Calteau, A., Scalvenzi, T., Pédron, J., \& Gugger, M. (2017). Insights into the Planktothrix genus: Genomic and metabolic comparison of benthic and planktic strains. Scientific Reports, 7 (1), 1-10.

- Pearson, L. A., Hisbergues, M., Börner, T., Dittmann, E., \& Neilan, B. A. (2004). Inactivation of an $\mathrm{ABC}$ transporter gene, $m c y H$, results in loss of microcystin production in the cyanobacterium Microcystis aeruginosa PCC 7806. Applied Environmental Microbiology., 70 (11), 6370-6378.

- Peperzak, L., \& Brussaard, C. P. (2011). Flow cytometric applicability of fluorescent vitality probes on phytoplankton. Journal of Phycology, 47 (3), 692-702.

- Pflugmacher, S. (2002). Possible allelopathic effects of cyanotoxins, with reference to 
microcystin-LR, in aquatic ecosystems. Environmental Toxicology: An International Journal, 17 (4), 407-413.

- Phelan, R. R., \& Downing, T. G. (2014). The localization of exogenous microcystin-LR taken up by a non-microcystin producing cyanobacterium. Toxicon, 89, 87-90.

- Puddick, J., Thomson-Laing, G., \& Wood, S. A. (2019). Microcystins in New Zealand: A review of occurrence, congener diversity and cell quotas. New Zealand Journal of Botany, 57 (2), 93-111.

- Puddick, J., Wood, S. A., Hawes, I., \& Hamilton, D. P. (2016). Fine-scale cryogenic sampling of planktonic microbial communities: Application to toxic cyanobacterial blooms. Limnology and Oceanography Methods, 14 (9), 600-609.

- R Core Team (2020). R: A language and environment for statistical computing. R Found ation for Statistical Computing, Vienna, Austria. URL https://www.R-project.org/.

- Rabalais, N., Diaz, R. J., Levin, L., Turner, R., Gilbert, D., \& Zhang, J. (2017). Dynamics and distribution of natural and human-caused hypoxia. Biogeosciences, 7, 585-619.

- Rantala, A., Fewer, D. P., Hisbergues, M., Rouhiainen, L., Vaitomaa, J., Börner, T., \& Sivonen, K. (2004). Phylogenetic evidence for the early evolution of microcystin synthesis. Proceedings of the National Academy of Sciences, 101 (2), 568-573.

- Rapala, J., Sivonen, K., Lyra, C., \& Niemelä, S. I. (1997). Variation of microcystins, cyanobacterial hepatotoxins, in Anabaena spp. as a function of growth stimuli. Applied Environmental Microbiology, 63 (6), 2206-2212.

- Renaud, S. L., Pick, F. R., \& Fortin, N. (2011). Effect of light intensity on the relative dominance of toxigenic and nontoxigenic strains of Microcystis aeruginosa. Applied Environmental Microbiology, 77(19), 7016-7022.

- Rinehart, K. L., Namikoshi, M., \& Choi, B. W. (1994). Structure and biosynthesis of toxins from blue-green algae (cyanobacteria). Journal of Applied Phycology, 6(2), 159-176.

- Rogers, S., Puddick, J., Wood, S. A., Dietrich, D. R., Hamilton, D. P., \& Prinsep, M. R. (2015). The effect of cyanobacterial biomass enrichment by centrifugation and GF/C filtration on subsequent microcystin measurement. Toxins, 7 (3), 821-834.

- Rohrlack, T., Dittmann, E., Henning, M., Börner, T., \& Kohl, J.-G. (1999). Role of microcystins in poisoning and food ingestion inhibition of Daphnia galeata caused by the cyanobacterium Microcystis aeruginosa. Applied Environmental Microbiology, 65 
(2), 737-739.

- Romero, M., Muro-Pastor, A. M., \& Otero, A. (2011). Quorum sensing Nacylhomoserine lactone signals affect nitrogen fixation in the cyanobacterium Anabaena sp. PCC7120. FEMS Microbiology Letters, 315 (2), 101-108.

- Roth, B. L., Poot, M., Yue, S. T., \& Millard, P. J. (1997). Bacterial viability and antibiotic susceptibility testing with SYTOX Green nucleic acid stain. Applied Environmental Microbiology, 63 (6), 2421-2431.

- Saito, K., Sei, Y., Miki, S., \& Yamaguchi, K. (2008). Detection of microcystin-metal complexes by using cryospray ionization-Fourier transform ion cyclotron resonance mass spectrometry. Toxicon, 51 (8), 1496-1498.

- Salmaso, N., Capelli, C., Shams, S., \& Cerasino, L. (2015). Expansion of bloom-forming Dolichospermum lemmermannii (Nostocales, Cyanobacteria) to the deep lakes south of the Alps: Colonization patterns, driving forces and implications for water use. Harmful Algae, 50, 76-87.

- Sangolkar, L. N., Maske, S. S., \& Chakrabarti, T. (2006). Methods for determining microcystins (peptide hepatotoxins) and microcystin-producing cyanobacteria. Water Research, 40 (19), 3485-3496.

- Sato, M., Murata, Y., Mizusawa, M., Iwahashi, H., \& Oka, S.-i. (2004). A simple and rapid dual-fluorescence viability assay for microalgae. Microbiol and Culture Collections, 20 (2), 53-59.

- Schatz, D., Keren, Y., Vardi, A., Sukenik, A., Carmeli, S., Börner, T., \& Kaplan, A. (2007). Towards clarification of the biological role of microcystins, a family of cyanobacterial toxins. Environmental Microbiology, 9 (4), 965-970.

- Sedmak, B., \& Elersek, T. (2005). Microcystins induce morphological and physiological changes in selected representative phytoplanktons. Microbial Ecology, 51, 508-515.

- Sedmak, B., \& Kosi, G. (1998). The role of microcystins in heavy cyanobacterial bloom formation. Journal of Plankton Research, 20 (4), 691-708.

- Sevilla, E., Martin-Luna, B., Vela, L., Bes, M. T., Fillat, M. F., \& Peleato, M. L. (2008). Iron availability affects $m c y D$ expression and microcystin-LR synthesis in Microcystis aeruginosa PCC7806. Environmental Microbiology, 10 (10), 2476-2483.

- Sharif, D. I., Gallon, J., Smith, C. J., \& Dudley, E. (2008). Quorum sensing in 
cyanobacteria: $\mathrm{N}$-octanoyl-homoserine lactone release and response, by the epilithic colonial cyanobacterium Gloeothece PCC6909. The ISME Journal, 2 (12), 1171-1182.

- Shi, L., Carmichael, W. W., \& Miller, I. (1995). Immuno-gold localization of hepatotoxins in cyanobacterial cells. Archives of Microbiology, 163 (1), 7-15.

- Simis, S. G., Huot, Y., Babin, M., Seppälä, J., \& Metsamaa, L. (2012). Optimization of variable fluorescence measurements of phytoplankton communities with cyanobacteria. Photosynthesis Research, 112 (1), 13-30.

- Singh, D. P., Tyagi, M., Kumar, A., Thakur, J., \& Kumar, A. (2001). Antialgal activity of a hepatotoxin-producing cyanobacterium, Microcystis aeruginosa. World Journal of Microbiology and Biotechnology, 17 (1), 15-22.

- Sivonen, K. (1990). Effects of light, temperature, nitrate, orthophosphate, and bacteria on growth of and hepatotoxin production by Oscillatoria agardhii strains. Applied Environmental Microbiology, 56 (9), 2658-2666.

- Smayda, T. J. (1997). Harmful algal blooms: Their ecophysiology and general relevance to phytoplankton blooms in the sea. Limnology and Oceanography, 42 (5 part 2), 11371153.

- Spassova, M., Mellor, I., Petrov, A., Beattie, K., Codd, G., Vais, H., \& Usherwood, P. (1995). Pores formed in lipid bilayers and in native membranes by nodularin, a cyanobacterial toxin. European Biophysics Journal, 24 (2), 69-76.

- Stebegg, R., Schmetterer, G., \& Rompel, A. (2019). Transport of organic substances through the cytoplasmic membrane of cyanobacteria. Phytochemistry, 157, 206-218.

- Steinberg, M. K., Lemieux, E. J., \& Drake, L. A. (2011). Determining the viability of marine protists using a combination of vital, fluorescent stains. Marine Biology, 158 (6), 14311437.

- Stewart, I., Schluter, P. J., \& Shaw, G. R. (2006). Cyanobacterial lipopolysaccharides and human health - A review. Environmental Health, 5 (1).

- Straub, C., Quillardet, P., Vergalli, J., De Marsac, N. T., \& Humbert, J.-F. (2011). A day in the life of Microcystis aeruginosa strain PCC 7806 as revealed by a transcriptomic analysis. PLoS One, 6 (1): e16208.

- Stroom, J. M., \& Kardinaal, W. E. A. (2016). How to combat cyanobacterial blooms: Strategy toward preventive lake restoration and reactive control measures. Aquatic 
Ecology, 50 (3), 541-576.

- Sukenik, A., Eshkol, R., Livne, A., Hadas, O., Rom, M., Tchernov, D., \& Kaplan, A. (2002). Inhibition of growth and photosynthesis of the dinoflagellate Peridinium gatunense by Microcystis sp. (cyanobacteria): A novel allelopathic mechanism. Limnology and Oceanography, 47 (6), 1656-1663.

- Tang, Y. Z., \& Dobbs, F. C. (2007). Green autofluorescence in dinoflagellates, diatoms, and other microalgae and its implications for vital staining and morphological studies. Applied Environmental Microbiology, 73 (7), 2306-2313.

- Tashyreva, D., \& Elster, J. (2015). Effect of nitrogen starvation on desiccation tolerance of Arctic Microcoleus strains (cyanobacteria). Frontiers in Microbiology, 6, 278.

- Tashyreva, D., Elster, J., \& Billi, D. (2013). A novel staining protocol for multiparameter assessment of cell heterogeneity in Phormidium populations (cyanobacteria) employing fluorescent dyes. PLoS One, 8 (2), e55283.

- Thakur, S., Cattoni, D. I., \& Nöllmann, M. (2015). The fluorescence properties and binding mechanism of SYTOX green, a bright, low photo-damage DNA intercalating agent. European Biophysics Journal, 44 (5), 337-348.

- Tillett, D., Dittmann, E., Erhard, M., Von Döhren, H., Börner, T., \& Neilan, B. A. (2000). Structural organization of microcystin biosynthesis in Microcystis aeruginosa PCC7806: An integrated peptide-polyketide synthetase system. Chemistry \& Biology, 7 (10), 753 764.

- Tillmann, U. (2003). Kill and eat your predator: A winning strategy of the planktonic flagellate Prymnesium parvum. Aquatic Microbial Ecology, 32 (1), 73-84.

- Tonk, L., Visser, P. M., Christiansen, G., Dittmann, E., Snelder, E. O., Wiedner, C., \& Huisman, J. (2005). The microcystin composition of the cyanobacterium Planktothrix agardhii changes toward a more toxic variant with increasing light intensity. Applied Environmental Microbiology, 71 (9), 5177-5181.

- Utkilen, H., \& Gjølme, N. (1992). Toxin production by Microcystis aeruginosa as a function of light in continuous cultures and its ecological significance. Applied Environmental Microbiology, 58 (4), 1321-1325.

- Van der Westhuizen, A., \& Eloff, J. (1985). Effect of temperature and light on the toxicity and growth of the blue-green alga Microcystis aeruginosa (UV-006). Planta, 163 (1), 55- 
59.

- Van Mooy, B. A., Hmelo, L. R., Sofen, L. E., Campagna, S. R., May, A. L., Dyhrman, S. T., \& Mincer, T. J. (2012). Quorum sensing control of phosphorus acquisition in Trichodesmium consortia. The ISME Journal, 6 (2), 422-429.

- Veldhuis, M. J., Cucci, T. L., \& Sieracki, M. E. (1997). Cellular DNA content of marine phytoplankton using two new fluorochromes: Taxonomic and ecological implications. Journal of Phycology, 33 (3), 527-541.

- Vézie, C., Rapala, J., Vaitomaa, J., Seitsonen, J., \& Sivonen, K. J. M. (2002). Effect of nitrogen and phosphorus on growth of toxic and nontoxic Microcystis strains and on intracellular microcystin concentrations. Microbial Ecology, 43 (4), 443-454.

- Wang, C., Feng, B., Tian, C., Tian, Y., Chen, D., Wu, X., \& Xiao, B. (2018). Quantitative study on the survivability of Microcystis colonies in lake sediments. Journal of Applied Phycology, 30 (1), 495-506.

- Wang, Z., Li, D., Cao, X., Song, C., \& Zhou, Y. (2015). Photosynthesis regulates succession of toxic and nontoxic strains in blooms of Microcystis (Cyanobacteria). Phycologia, 54 (6), 640-648.

- Wei, N., Hu, L., Song, L., \& Gan, N. (2016). Microcystin-bound protein patterns in different cultures of Microcystis aeruginosa and field samples. Toxins, 8 (10): 293.

- White, S. H., Duivenvoorden, L. J., \& Fabbro, L. D. (2005). A decision-making framework for ecological impacts associated with the accumulation of cyanotoxins (cylindrospermopsin and microcystin). Lakes \& Reservoirs Research \& Management. 10 (1), 25-37.

- Wiedner, C., Visser, P. M., Fastner, J., Metcalf, J. S., Codd, G. A., \& Mur, L. R. (2003). Effects of light on the microcystin content of Microcystis strain PCC 7806. Applied Environmental Microbiology., 69 (3), 1475-1481.

- Wood, S. A., Dietrich, D. R., Cary, S. C., \& Hamilton, D. P. (2012). Increasing Microcystis cell density enhances microcystin synthesis: A mesocosm study. Inland Waters, 2 (1), $17-22$.

- Wood, S. A., Heath, M. W., Holland, P. T., Munday, R., McGregor, G. B., \& Ryan, K. G. (2010). Identification of a benthic microcystin-producing filamentous cyanobacterium (Oscillatoriales) associated with a dog poisoning in New Zealand. Toxicon, 55 (4), 897- 
903.

- Wood, S. A., Rueckert, A., Hamilton, D. P., Cary, S. C., \& Dietrich, D. R. (2011). Switching toxin production on and off: intermittent microcystin synthesis in a Microcystis bloom. Environmental Microbiology Reports, 3 (1), 118-124.

- Xiao, M., Li, M., \& Reynolds, C. S. (2018). Colony formation in the cyanobacterium Microcystis. Biological Reviews, 93 (3), 1399-1420.

- Yang, Z., Kong, F., Yang, Z., Zhang, M., Yu, Y., \& Qian, S. (2009). Benefits and costs of the grazer-induced colony formation in Microcystis aeruginosa. Annales de LimnologieInternational Journal of Limnology. 45(3): 203-208.

- Yoshida, M., Yoshida, T., Satomi, M., Takashima, Y., Hosoda, N., \& Hiroishi, S. (2008). Intra-specific phenotypic and genotypic variation in toxic cyanobacterial Microcystis strains. Journal of Applied Microbiology, 105 (2), 407-415.

- Yoshida, M., Yoshida, T., Takashima, Y., Hosoda, N., \& Hiroishi, S. (2007). Dynamics of microcystin-producing and non-microcystin-producing Microcystis populations is correlated with nitrate concentration in a Japanese lake. FEMS Microbiology Letters, 266 (1), 49-53.

- Young, F. M., Thomson, C., Metcalf, J. S., Lucocq, J. M., \& Codd, G. A. (2005). Immunogold localisation of microcystins in cryosectioned cells of Microcystis. Journal of Structural Biology, 151 (2), 208-214.

- Zeller, P., Méjean, A., Biegala, I., Contremoulins, V., \& Ploux, O. (2016). Fluorescence in situ hybridization of Microcystis strains producing microcystin using specific mRNA probes. Letters in Applied Microbiology, 63 (5), 376-383.

- Zetsche, E.-M., \& Meysman, F. J. (2012). Dead or alive? Viability assessment of microand mesoplankton. Journal of Plankton Research, 34 (6), 493-509.

- Zhu, T., \& Xu, X. (2013). Efficacy of a dual fluorescence method in detecting the viability of overwintering cyanobacteria. Letters in Applied Microbiology, 57 (3), 174-180.

- Zilliges, Y., Kehr, J.-C., Meissner, S., Ishida, K., Mikkat, S., Hagemann, M., \& Dittmann, E. (2011). The cyanobacterial hepatotoxin microcystin binds to proteins and increases the fitness of Microcystis under oxidative stress conditions. PLoS One, 6 (3): e17615.

- Zilliges, Y., Kehr, J.-C., Mikkat, S., Bouchier, C., de Marsac, N. T., Boerner, T., \& Dittmann, E. (2008). An extracellular glycoprotein is implicated in cell-cell contacts in the toxic 
cyanobacterium Microcystis aeruginosa PCC 7806. Journal of Bacteriology, 190 (8), 2871-2879.

- Zurawell, R. W., Chen, H., Burke, J. M., \& Prepas, E. E. (2005). Hepatotoxic cyanobacteria: A review of the biological importance of microcystins in freshwater environments. Journal of Toxicology and Environmental Health, Part B, 8 (1), 1-37. 